UNIVERSIDADE DE SÃO PAULO

FACULDADE DE RLOSORA, LFIRAS E CIÊNCIAS HUMANAS

DEPARTAMENTO DE CIÊNCIA POÚTCA

PROGRAMA DE PÓS-GRADUAÇÃO EM CIÊNCIA POÚTCA

Govemadores Estaduais e Partidos Polític os na Reforma Administrativa do Govemo RK: negociação e análise da votação

Ivo Femando Yoshida

Dissertação apresentada ao Programa de Pós-Graduação em Ciência Política, do Departamento de Ciência Política da Faculdade de Filosofia, Letras e Ciências Humanas da Universidade de São Paulo, para obtenção do tútulo de Mestre em Ciência Política.

Orientadora: Profa. Dra. Marta T. S. Arretche

São Paulo

2006 


$$
\text { UNIVERSIDADE DE SÃO PAULO }
$$

FACULDADE DE FILOSOFIA, LETRAS E CIÊNCIAS HUMANAS DEPARTAMENTO DE CIÊNCIA POLÍTICA PROGRAMA DE CIÊNCIA POLÍTICA

\section{Governadores Estaduais e Partidos Políticos na Reforma Administrativa do Governo FHC: negociação e análise da votação}

Ivo Fernando Yoshida 
“A eficiência e a organização não devem ser consideradas as metas máximas na vida. Elas são meios, meios limitados, que capacitam os homens e mulheres a levar vidas melhores e mais felizes". (Noel Annan. Prefácio a Isaiah Berlin. Estudos sobre a Humanidade) 


\section{DEDICATÓRIA}

À minha querida mãe, Elza Goto Yoshida In memoriam 


\section{AGRADECIMENTOS}

Mais uma etapa se fecha com essa dissertação de mestrado. Nesse sentido, é inevitável que eu faça alguns agradecimentos às pessoas que tanto contribuíram para que esse passo pudesse ser dado.

Antes de tudo, gostaria de agradecer o apoio, o carinho e a compreensão dados pelos meus irmãos (Pri, Binho, Valéria) e pelo meu pai, sem os quais não teria conseguido sequer iniciar os meus estudos.

Agradeço também à paciência e ao carinho dados pela minha namorada, Miriam Akemi, que me ajudou a suportar as angústias e as incertezas ao longo desse trabalho.

Além disso, se, por um lado, esse trabalho corre o risco de não estar satisfatório, por outro, ele sequer poderia ser imaginado se não houvesse contado com a ajuda das mais diversas pessoas e instituições.

Primeiramente, gostaria de agradecer a minha orientadora por ter desempenhado uma função muito além da que lhe era devida. Pessoa a qual me orientou não apenas no que se refere aos estudos, mas também, na minha vida em sentido mais amplo. Agradeço então à Profa. Marta T. S. Arretche pelos ensinamentos, dicas, conselhos e, principalmente, críticas ao longo desse período da minha vida.

Agradeço também à Sandra Gomes, ao Prof. Fernando Limongi e à Andrea Freitas por terem disponibilizado os dados que foram fundamentais para que esse trabalho pudesse ser feito e por, diversos momentos, terem esclarecido dúvidas quanto a esses dados. Agradeço aos professores Eduardo Marques e Eduardo Kugelmas pelas valiosas sugestões na qualificação do texto da dissertação.

Agradeço também aos funcionários da secretaria do Departamento de Ciência Política (Márcia, Rai, Vivian, Léo, Ana Maria,) por sempre estarem dispostos a ajudar quando foi preciso. Agradeço à Coordenação de Aperfeiçoamento de Pessoal de Nivel Superior (CAPES) por ter concedido bolsa para realização do mestrado e à Fundação Ford por ter concedido a bolsa para realização do curso de metodologia quantitativa em ciências sociais na UFMG.

Por fim, mas de maneira alguma menos importante, gostaria de fazer um agradecimento especial às pessoas que, sem dúvida alguma, são essenciais na vida de qualquer pessoa. Agradeço, portanto, aos meus amigos que muitas vezes podem não ter contribuído diretamente para a pesquisa, mas foram extremamente importantes para enfrentar os diversos desafios e problemas que se apresentaram. 
Quero agradecer aos meus amigos de graduação (Antônio Luiz C. M. Barretto; Fábio Borges, Luciana Tsukada, Rafael Bertolin e Vanderléia Radaelli) cuja amizade e a contribuição nas mais distintas esferas felizmente não ficou restrita ao período de Araraquara.

Agradeço também aos meus amigos "da rua" e "de infância" (Diego e sua querida família, Mariane, Fraviotz, André e Marcelo Salim, Jonas, Dindo, Pulga, Doma, Érika, Juliano, Alex, Gú, Paulo, Cris, Pri, Andrezinho) pela sua contribuição a qual certamente vai muito além dessa fase do mestrado.

Além dessas pessoas, gostaria de agradecer às minhas amigas da USP (Kellen, Renata, Rosi, Thais), as quais me ajudaram a resolver problemas muito além dos de pesquisa. E, por fim, agradeço os meus amigos de mestrado Zé Veríssimo e Erik Marques.

À todas essas pessoas e às que, por falha reconhecidamente minha, esqueci de mencionar meus mais sinceros agradecimentos. 


\section{RESUMO}

O presente estudo analisa a reforma administrativa elaborada e proposta pelo governo Fernando Henrique Cardoso (FHC) em seu primeiro mandato (1995-1998). Para tanto, o trabalho analisou, especialmente, os argumentos da literatura a respeito da participação dos governadores estaduais no processo da reforma. A pesquisa se baseou principalmente em dados coletados sobre a votação nominal da reforma administrativa do governo FHC na Câmara de Deputados em 1997 e em informações coletadas a respeito do apoio dos governadores estaduais à reforma. A conclusão do estudo é de que, de um lado, o apoio ativo dos governadores estaduais à reforma não pode ser explicado apenas pela situação fiscal e financeira dos estados e, de outro lado, que a participação efetiva dos governadores estaduais na votação somente pode ser entendida através da mediação dos partidos políticos.

\section{PALAVRAS-CHAVE}

Reforma Administrativa; Partidos Políticos; Governadores Estaduais; Negociação; Votação de Emendas Constitucionais.

\section{ABSTRACT}

The present study analyze the administrative reform elaborated and proposed by the president Fernando Henrique Cardoso (FHC), during his first term (1995-1998). In this way, it presents a review of the literature arguments, especially, about the state governors influence in the reform outcomes. The resarch was based on data about nominal voting at the House of Representantives in 1997 and on collected information about state governors support to this reform. The conclusion of the study is, in one hand, that active state governors support can't be explicated only by fiscal and financial situation of the states and, on the other hand, that efective participation of state governors on voting only can be understood through the mediation of political parties.

\section{KEY WORDS}

Administrative Reform; Political Parties; State Governors; Negotiation; Vote of the Constitutional Amendments. 


\section{SUMÁRIO}

Resumo............................................................................. VII

Abstract....................................................................................... VII

Índice.......................................................................................... IX

Apresentação ................................................................... 1

O objeto de estudo................................................................ 3

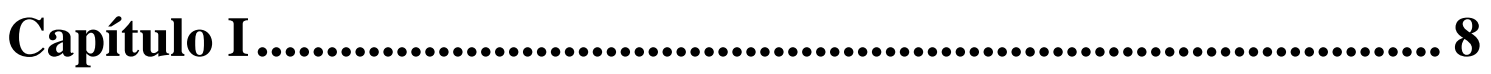

Capítulo II ............................................................................ 27

Conclusão.................................................................................. 84

Referências Bibliográficas......................................................... 89 


\section{ÍNDICE}

Apresentação...................................................................................................................

O objeto de estudo: Plano Diretor de Reforma do Aparelho do Estado

(PDRAE)

\section{Capítulo I - Revisão Bibliográfica: negociação e votação da reforma} administrativa do governo FHC........................................................................................8

Negociação: câmara de reforma do Estado, sindicatos trabalhistas e governadores estaduais.

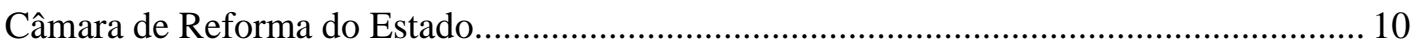

O Papel dos sindicatos e das associações trabalhistas ............................................................. 11

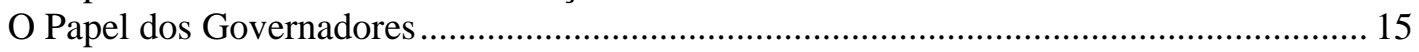

Tramitação Legislativa: emendas constitucionais e as instituições políticas no Brasil

\section{Capítulo II - Análise da Votação da Reforma Administrativa do Governo} FHC: o papel partidos políticos e dos governadores estaduais.........................27

Material e Método para analisar as votações da reforma administrativa ................... 28

Tramitação do PEC/173 nas Comissões do Congresso................................................ 35

Disciplina Partidária na Câmara dos Deputados ...................................................... 36

A participação dos governadores estaduais na votação do PEC/173......................... 47

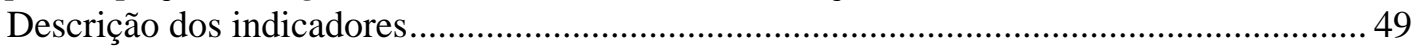

Análise do apoio ativo dos governadores ao PDRAE........................................................... 60

Análise do papel dos governadores estaduais na votação do PEC 173................................ 75

Conclusão .84

Referências Bibliográficas 


\section{Apresentação}

A presente dissertação de mestrado analisa a reforma administrativa elaborada e proposta pelo governo Fernando Henrique Cardoso (FHC) em seu primeiro mandato (1995-1998) como presidente do Brasil.

Para tanto, vamos discutir os processos e os atores com os quais o governo FHC discutiu e negociou o projeto de reforma e, especialmente, como foi a sua votação e quais foram os atores relevantes para sua aprovação.

Os estudos sobre a reforma administrativa do governo FHC indicam que uma estrutura composta por distintos incentivos levou os governadores estaduais a apoiarem esta reforma. Além disso, indica ainda que a participação dos governadores na reforma em questão foi importante tanto para sua viabilidade política (Gaetani, 2000; Gaetani e Heredia, 2002, p. 14; Melo, 2002, p. 172), como também, para a sua aprovação no Parlamento (Abrucio e Costa, 1999; Schneider, 2001, p. 9).

No entanto, a análise empírica realizada nesse trabalho aponta resultados distintos dos apontados pela literatura tanto no que se refere às motivações dos governadores estaduais para apoiar a reforma, como sobre sua influência efetiva na votação da reforma administrativa do governo FHC.

Nesse sentido, dividimos o trabalho em três capítulos, além da introdução. Partiremos de uma Introdução com uma breve descrição do objeto de estudo em questão, qual seja, o projeto de reforma administrativa do governo FHC (Plano Diretor de Reforma do Aparelho do Estado - PDRAE) e seus principais objetivos.

No primeiro capítulo, expomos, a partir do estudo da literatura pertinente, os atores envolvidos no processo de negociação do projeto de reforma antes do seu encaminhamento ao legislativo. 
Damos especial atenção às negociações com dois grupos de atores considerados relevantes tanto pela literatura referente à reforma do Estado em geral (sindicatos e associações de funcionários públicos), como também, pelos estudos sobre o sistema político brasileiro (os governadores estaduais).

Em seguida, nesse mesmo capítulo, analisamos os argumentos levantados pela literatura sobre as relações entre os poderes executivo e legislativo no Brasil e também sobre a influência dos governadores estaduais na dinâmica política do país.

No segundo capítulo, analisamos a votação da reforma administrativa do governo FHC na Câmara dos Deputados. ${ }^{1}$ Nossa intenção nesse capítulo é avaliar argumentos encontrados na literatura tanto os, especificamente, relacionados à reforma administrativa do governo FHC, quanto, argumentos mais gerais sobre as instituições políticas brasileiras.

Portanto, nesse capítulo, analisamos, em primeiro lugar, a representatividade dos partidos políticos nas votações da reforma administrativa, em seguida; as motivações dos governadores estaduais para apoiá-la e, por fim; o papel dos governadores na sua aprovação legislativa. $^{2}$

Por fim, no terceiro e último capítulo, sistematizamos os resultados encontrados através da análise da votação da reforma administrativa proposta pelo governo FHC.

\footnotetext{
${ }^{1}$ Embora a reforma administrativa tenha sido votada também no Senado Federal, não trabalharemos com esses dados. Tanto porque o governo FHC detinha uma ampla maioria no Senado (Gaetani, 2000, p. 9), como porque, de acordo com Melo (2002), a reforma administrativa foi votada no Senado sem mudanças substantivas.

${ }^{2}$ Embora a reforma administrativa do governo FHC tenha sido aprovada no legislativo com "razoável fidelidade ao texto original” (Melo, 2002; p. 153; Bressan, 2002, p. 370), a proposta do governo FHC não foi implementada na administração pública brasileira. Para uma discussão sobre os motivos pelos quais a reforma em questão não foi implementada, ver Melo (2002); Lima Jr. (1998); Andrews, Comini e Vieira (1999); Costa (1998); Bressan (2002); Marcelino (1998); Abrucio (1997); Gaetani e Heredia (2002); Schneider (2001); Cheibub (2000); Rezende (2002a; 2002b; 2004).
} 


\section{O objeto de estudo: Plano Diretor de Reforma do Aparelho do Estado (PDRAE)}

A reforma do Estado e do seu aparelho entrou na agenda dos países centrais e de alguns países subdesenvolvidos a partir de meados dos anos 1970. Este tema derivou principalmente da crise econômica e fiscal pela qual passaram estes estados em fins da década de 70 associados aos efeitos derivados da globalização e das novas tecnologias de informação.

Neste contexto, emergiram críticas relacionadas ao padrão de desenvolvimento adotado pelos países capitalistas nos anos do pós-segunda guerra mundial. Os críticos desta corrente alegavam que o intervencionismo do Estado nas economias nacionais resultou em distorções nestes países.

"Sem dúvida, num sistema capitalista, Estado e mercado, direta ou indiretamente, são as duas instituições centrais que operam na coordenação dos sistemas econômicos. Dessa forma, se uma delas apresenta funcionamento irregular, é inevitável que nos deparemos com uma crise. Foi assim nos anos 20 e 30, em que claramente foi o mau funcionamento do mercado que trouxe em seu bojo uma crise econômica de grandes proporções. Já nos anos 80 é a crise do Estado que põe em xeque o modelo econômico em vigência”. (MARE, 1995b, p. 5).

Nesse sentido, foram propostas medidas para alterar o padrão de intervenção do Estado prevalecente até meados dos anos 1970. Abrucio (1997) discutiu brevemente os objetivos que balizavam as alterações buscadas pelos Estados nacionais.

Na visão do autor, três medidas gerais foram propostas para os mais diferentes países com o objetivo de alterar o padrão de intervenção do Estado na economia e na sociedade. A visão prevalecente foi a de que era necessário: a) redefinir (reduzir) o papel do Estado na economia; b) reduzir os gastos públicos e; c) reformar o aparelho do Estado em direção à denominada administração gerencial.

“Grosso modo, a redefinição do papel do Estado na economia e a tentativa de reduzir os gastos públicos na área social - tarefa esta nem sempre bem sucedida foram as duas saídas mais comuns à crise das dimensões econômica e social do antigo tipo de Estado. Para responder ao esgotamento do modelo burocrático weberiano, foram introduzidos, em larga escala, padrões gerenciais na 
administração pública, inicialmente e com mais vigor em alguns países do mundo anglo-saxão (Grã-Bretanha, Estados Unidos, Austrália e Nova Zelândia), e depois, gradualmente, na Europa Continental e Canadá”. (Abrucio, 1997, p. 7).

Nesse contexto, o governo do presidente Fernando Henrique Cardoso, eleito em 1994, criou o Ministério da Administração e Reforma do Estado (MARE) logo no começo do seu primeiro mandato (1995) e incumbiu esse ministério da tarefa de elaborar um projeto para reformar a administração pública brasileira. ${ }^{3}$

No mesmo ano (1995), o Ministério elaborou um projeto que deveria servir de referência para as ações voltadas à reforma da administração pública brasileira, o Plano Diretor de Reforma do Aparelho do Estado (PDRAE).

De acordo com o ministro responsável pela elaboração do plano (Luiz Carlos Bresser Pereira), tratava-se, sobretudo, de um projeto que buscava reformar o aparelho do Estado para aumentar a sua capacidade efetiva de atuação.

A reforma pretendia alterar as instituições prevalecentes no âmbito estatal para que essas pudessem promover uma atuação mais efetiva e mais eficiente do Estado. (Pereira, 1997; Pereira e Spink, 2003).

A reforma proposta pelo MARE se enquadrava no que ficou conhecido como “segunda geração de reformas”. ${ }^{4}$ (Heredia e Gaetani, 2002; Melo, 2002, p. 153). O objetivo de reformas desse tipo não seria a busca do "Estado mínimo” ("reformas de primeira geração”) e sim o fortalecimento das suas instituições a fim de capacitá-lo a corrigir as falhas de mercado e criar um ambiente mais favorável para seu desenvolvimento. $^{5}$

\footnotetext{
${ }^{3}$ Para uma discussão sobre o histórico de reformas da administração pública no Brasil, ver Lima Jr. (1998) e Pereira (1998).

${ }^{4}$ Sobre o conceito de reformas de "segunda geração", ver Evans (1993); Grindle (2000a); Costa (1998).

${ }^{5}$ A questão do fortalecimento do Estado pela via da reforma administrativa, proposta por Bresser Pereira (1998), é questionada por Andrews e Kouzmin (1998a; 1998b). Os autores argumentam que, embora Bresser Pereira diferencie constantemente a sua proposta de reforma administrativa das reformas em direção ao "Estado mínimo", há fortes evidências de que o ministro, na verdade, baseava as suas idéias nas propostas da Escolha Pública - fortemente, favorável ao desmonte do Estado. Andrews e Kouzmin (1998a; 1998b) alegam que a estratégia de Bresser era diferenciar a sua proposta das propostas da Escola
} 
“O Plano foi informado pelo New Public Management (novo gerenciamento público), que foi amplamente disseminado pelo MARE. No entanto, o Plano também incorporava um forte componente de 'reformas weberianas' (Heredia e Schneider, no prelo) na medida em que identificava e insulava politicamente burocracias estratégicas associadas ao que o Plano denominava de funções típicas de estado (burocracia fazendária, de arrecadação, planejamento, controle e orçamentação, entre outras). Essa estratégia é consistente com a proposta de fortalecimento da capacidade institucional dos países, o que é característico da 'segunda onda' de reformas do Estado promovida pelas agências internacionais”. (Diniz e Boschi, 1997; Kauffman, no prelo apud Melo, 2002, p. 153).

Em resumo, o PDRAE tinha dois objetivos principais: de um lado, buscava diminuir os custos da administração pública (cost less) e, por outro, buscava aumentar a eficiência do aparelho do Estado (work better). (Rezende, 2002a; 2002b; 2004).

A diminuição dos custos da administração seria feita com medidas tais como: a quebra da estabilidade do serviço público; mudanças nas regras de remuneração dos servidores públicos; ${ }^{6}$ além da privatização das empresas estatais, que atuam no setor de bens e serviços e que poderiam ser assumidas pelo mercado.

Na visão do ministério, essa última medida (privatização das empresas estatais) atenderia também ao objetivo de aumentar a eficiência do aparelho do Estado. Ou seja, como meio para alcançar o aumento de eficiência almejado, o Ministério da Administração e da Reforma do Estado entendeu que seria necessário redefinir as funções do Estado assim como realizar mudanças na forma de controle presente no setor público.

O projeto previa que a produção de bens e serviços e a execução de "serviços não-exclusivos do Estado” não deveriam ser mais executados por órgãos da

da "Escolha Pública" em um contexto em que as reformas em direção ao "Estado mínimo" têm pouca legitimidade. Para a réplica ao argumento de Andrews e Kouzmin (1998a; 1998b), ver Pereira (s/d).

${ }^{6}$ Martins (1995, p. 11) aponta qual seria a justificativa para a incorporação da quebra da estabilidade dos servidores público no plano de reforma: "A Constituição de 1988, embora tenha estabelecido alguns princípios pertinentes para a modernização da administração pública, tornou, de forma contraditória, bastante difícil qualquer reforma das estruturas do Estado ao conceder benefícios aos servidores públicos sem deveres correspondentes (o que torna a introdução do critério da produtividade quase impossível) e ao conceder estabilidade a todos os servidores com mais de cinco (e em alguns casos apenas dois) anos de serviço. Em resumo, a Constituição conseguiu congelar o status quo". 
administração pública. A execução dessas duas funções deveria ser transferida para empresas privadas e organizações públicas não-estatais ${ }^{7}$, respectivamente. $^{8}$

Os novos executores dessas funções seriam autônomos no que se refere à utilização e gestão dos recursos (input), porém deveriam firmar contratos de gestão com os ministérios setoriais, nos quais estariam especificadas as quantidades de recursos a serem pagas pelos serviços prestados, bem como, as metas que essas organizações (ou empresas) deveriam atingir (output).

Dessa forma, o padrão de avaliação da burocracia passaria do "controle de meios” (característico do modelo burocrático) para o “controle de resultados” (característico do modelo gerencial).

“Tornar gerentes públicos mais autônomos significa fazê-los mais eficientes, dada a complexidade dos problemas modernos que os governos enfrentam em um mundo de rápidas mudanças. Fazê-los mais accountable significa desenvolver novas formas de planejamento estratégico e de controle. O objetivo é que o Estado - e mais amplamente a sociedade - usem os limitados recursos disponíveis de uma maneira melhor e mais eficiente, e também de uma maneira mais democrática". (Pereira, 2002, p. 18).

Já os órgãos que controlariam as agências executivas - assim como, os responsáveis pela definição de metas e objetivos a serem cumpridos pelo Estado (outcomes) $^{9}$ - seriam mantidos de propriedade do Estado. O MARE considerou que algumas funções estratégicas e típicas do Estado não poderiam ser repassadas nem às empresas privadas, nem às organizações da sociedade civil. (Marcelino, 1998).

Além das funções de definição de metas e controle sobre as agências executivas, o plano previa ainda a manutenção de outros órgãos dentro do aparelho do Estado. A

\footnotetext{
${ }^{7}$ Hospitais, universidades, centros de pesquisa são alguns exemplos de organizações que seriam públicas, porém não-estatais.

${ }^{8} \mathrm{O}$ repasse das funções do Estado para o mercado e para organismos não-governamentais foi denominado de privatização e publicização, respectivamente. De acordo com MARE (1995b), a diferença entre as duas categorias é que enquanto em uma as funções são executadas por instituições com fins lucrativos (privatização) na outra as atividades seriam realizadas por instituições sem a possibilidade de auferir lucros (publicização).

9 Sobre a diferença entre os conceitos de output e outcomes previstas nas reformas gerenciais, ver Richardson (2003).
} 
execução de algumas atividades (atividades exclusivas) ${ }^{10}$ continuaria de responsabilidade do Estado.

De acordo com o Plano, esses setores, que permanecessem de propriedade do Estado, deveriam ter a qualidade dos seus quadros aumentada. Portanto, os setores encarregados (i) pela formulação e pela fiscalização de políticas públicas (núcleo estratégico), assim como, (ii) os responsáveis pelas funções que não poderiam ser assumidas pelos atores da sociedade civil (atividades exclusivas), deveriam ter seus cargos e salários valorizados e receber incentivos para melhorar a sua performance.

Para esses setores, portanto, as reformas seriam em direção à formação de uma burocracia weberiana (profissionalizada, impessoal, recrutada a partir de processos meritocráticos) ${ }^{11}$ com salários compatíveis aos percebidos por profissionais da iniciativa privada com funções e treinamento equivalente (Heredia e Gaetani, 2002, p. 16; Melo, 2002).

Resumidamente, estas seriam as principais áreas onde o PDRAE objetivava atuar. Portanto, o PDRAE, embora pretendesse diminuir o tamanho da administração pública, não visava apenas desconstitucionalizar (Melo, 2002). Como observamos, de acordo com o projeto, haveria a introdução de novas medidas e instituições na administração pública brasileira, as quais beneficiariam alguns atores.

Passaremos agora à exposição dos argumentos levantados pela literatura sobre os processos de negociação e votação da reforma administrativa do governo FHC.

\footnotetext{
${ }^{10}$ De acordo com o MARE (1995b), atividades exclusivas "são serviços em que se exerce o poder extroverso do Estado - o poder de regulamentar, fiscalizar, fomentar”. Os exemplos são polícia, órgãos de regulação e controle entre outros.

${ }^{11}$ Como afirma Alverga (2003, p. 29) e Lima Jr. (1998), reforma a qual nunca conseguiu ser implantada de fato no setor público brasileiro, a despeito das sucessivas tentativas de reforma nessa direção (reforma tentada pelo DASP em 1938; pela Comissão Amaral Peixoto em 1963 e pelo decreto-lei no. 200 de 1967 do governo militar).
} 


\section{Capítulo I - Revisão Bibliográfica: negociação e votação da reforma administrativa do governo FHC}

Nesse capítulo, serão tratados os argumentos da literatura sobre a reforma administrativa do governo FHC e sobre as instituições políticas brasileiras.

Serão apresentadas primeiramente as explicações sobre as negociações em torno do PDRAE antes do seu encaminhamento ao legislativo. Especificamente, pretendemos mostrar nessa primeira parte as razões pelas quais o MARE conseguiu negociar a sua proposta de reforma com determinados atores e não, com outros.

Iniciaremos com uma breve exposição das negociações no interior do Executivo e, posteriormente, passaremos às razões apontadas pela literatura para explicar a nãonegociação do MARE com os sindicatos e associações dos trabalhadores. Por fim, apresentaremos as negociações que se efetivaram entre o Ministério e os governadores estaduais.

Após essa parte, apresentaremos os argumentos levantados sobre as instituições políticas no Brasil. Nessa parte, seguiremos a divisão normalmente feita nos estudos referentes ao tema entre autores que indicam baixa governabilidade no sistema político brasileiro e autores que indicam que o executivo no Brasil consegue a "cooperação forçada” do legislativo nas votações de matérias de seu interesse.

\section{Negociação: câmara de reforma do Estado, sindicatos trabalhistas e governadores estaduais}

A importância das negociações em torno do PDRAE antes do seu envio à votação no Congresso Nacional é evidenciada por essa citação de Melo (2002).

"O intenso processo de negociação, na realidade, precedeu, à sua apresentação, formal à Câmara: a PEC 173, que foi finalmente enviada ao Congresso, já era a 58 versão do projeto”. (Melo, 2002, p. 153). 
Essas negociações (antes do envio do projeto ao Congresso) pretendiam alinhar os incentivos dos atores e concentrar apoio para que a tramitação da proposta no legislativo fosse menos custosa e com maior probabilidade de ser bem-sucedida (Gaetani e Heredia, 2002, p.14).

Entretanto, as negociações da reforma com os diferentes atores não tiveram os mesmos resultados. Ou seja, se, por um lado, as discussões do MARE com os atores no interior de executivo e com os governadores estaduais foram relativamente bemsucedidas, por outro, a negociação entre o ministério em questão e os sindicatos dos trabalhadores não teve o mesmo fim.

Embora os sindicatos de funcionários públicos sejam normalmente tomados como atores relevantes nos processos decisórios que envolvem reforma do Estado ${ }^{12}$, Melo (2002) e outros autores (Silva, 2001; Cheibub, 2000; Gaetani, 2000) alegaram que, no caso da reforma administrativa brasileira, esses atores foram excluídos das negociações da reforma. ${ }^{13}$

Por outro lado, a negociação da reforma administrativa do governo FHC com os atores no interior do executivo e com os governadores estaduais foi relativamente bemsucedida. O ministro da administração e reforma do Estado, Bresser Pereira, conseguiu no interior do executivo a autonomia necessária para levar à frente a reforma administrativa e, principalmente, obteve o apoio dos governadores estaduais para realizá-la. ${ }^{14}$

\footnotetext{
${ }^{12}$ Um estudo que demonstra a importância dos sindicatos em processos de reforma é o de Baccaro e Locke (1997). Para uma crítica aos trabalhos que dão excessiva importância ao poder de decisão e de veto aos sindicatos dos funcionários públicos, ver Grindle (2000a; 2000b).

${ }^{13}$ Esse fato pôde ser confirmado com as notícias veiculadas pela mídia na época. "CUT só monitora a votação", Folha de S. Paulo (FSP), 24/Out/95; "CUT diz que vai negociar”, FSP, 13/Fev/96; "Bresser diz que não negocia com a CUT”, FSP, 13/Fev/96; “CUT ainda não definiu posição”, FSP, 27/Mar/96; "Vicentinho chama servidor de 'peão mole'“, FSP, 30/Out/96.

${ }^{14}$ Gaetani (2000, p. 12) indica como evidência da cooperação dos governos estaduais com a reforma administrativa do governo FHC a criação do "Fórum Nacional de Secretarias da Administração Estadual" sob coordenação e liderança do MARE e com o propósito de coordenar esforços e trocar experiências de reforma entre as administrações públicas estaduais.
} 
As explicações para que a reforma administrativa brasileira tenha sido um caso de reforma "quase-negociada" - nos termos de Melo (2002) - serão apresentadas abaixo.

\section{Câmara de Reforma do Estado}

O PDRAE serviu de base para a discussão e negociação do MARE com diferentes atores. Inicialmente, foi constituído um fórum no interior do executivo (Câmara de Reforma do Estado) para conseguir o apoio dos atores relevantes dessa esfera à reforma administrativa.

Além do MARE, fizeram parte dessa câmara de negociações os ministérios do Planejamento, da Fazenda, do Trabalho, da Previdência Social, a Casa Civil e a Secretaria-Geral da Presidência. (Gaetani e Heredia, 2002, p. 13).

O objetivo dessas negociações seria o de coordenar as distintas opiniões, que vigoravam no interior da presidência, para viabilizar uma ação concertada dos ministérios em direção à reforma do setor público. (Melo, 2002).

"Other members of the inner circle of the President - the Ministry of Planning José Serra and the Minister of Education, Paulo Renato Souza - regarded it with considerable suspicion. Carvalho [chefe da Casa Civil] did not share Bresser Pereira's voluntarism or his insistence on the need to introduce wholesale changes in public organizations functioning structures. Jorge [secretário-geral da presidência] did not think that constitutional reform was a requirement to modernize the federal executive. Serra did not see state reform as a big priority and Souza was afraid of the impact of proposed reforms on the federal universities". (Gaetani e Heredia, 2002, pp. 13-14).

Como podemos ver a partir da citação acima, a proposta de Bresser Pereira, ministro do MARE, fora vista com desconfiança pelos outros participantes da Câmara de Reforma do Estado. 
No entanto, de acordo com Gaetani e Heredia (2002), o ministro conseguiu garantir autonomia e liberdade junto ao presidente para levar em frente a discussão e a negociação da reforma administrativa.

“Cardoso's speech on the occasion in which he publicly supported amendment was, nevertheless, revealing. The President said that Bresser had ahead of him three main tasks: convincing public opinion, persuading the Congress, and last but not least, conquering the government his ideas”. (Gaetani e Heredia, 2002, p. 14).

As razões apresentadas por Gaetani e Heredia (2002, p. 14) para Bresser Pereira ter conseguido essa autonomia em relação à condução das negociações e do encaminhamento da reforma administrativa estariam relacionadas, principalmente, ao fato de (1) não ser do interesse do Presidente envolver-se em negociações demoradas a respeito de detalhes técnicos da proposta de reforma; e (2) dos bons resultados das negociações preliminares de Bresser Pereira com alguns atores relevantes - em particular, as negociações com os governadores dos estados da Federação, que passaram a apoiar a reforma após as conversas com o ministro.

Devido a esses fatores, portanto, o Ministro da Administração e Reforma do Estado conseguiu garantir a autonomia necessária dentro do executivo para levar à frente o seu projeto.

O Papel dos sindicatos e das associações trabalhistas

Os fatores apresentados como os responsáveis pelo fracasso da negociação do MARE com os sindicatos trabalhistas se referem, principalmente, aos problemas de organização interna tanto do governo como das associações trabalhistas.

Melo (2002, p. 170-172) atribuiu a dois fatores principais o "malogro das negociações no plano da representação de interesses”. Para ele, tanto (1) a indefinição em relação ao ator governamental que deveria assumir a negociação com os sindicatos (MARE ou Casa Civil), assim como, (2) a radicalização das posições 
assumidas - tanto pelos sindicatos como pelo governo - seriam os principais fatores responsáveis pelo fracasso das negociações com os sindicatos dos trabalhadores.

Associada à explicação de Melo (2002), Gaetani (2000) alega que, em última instância, o governo FHC não estava preocupado em ver seus atos aprovados por parte do funcionalismo público. Para Gaetani (2000), isso seria derivado do fato de parte do funcionalismo público não representar uma base eleitoral importante para o governo FHC.

"Los perdedores potenciales eran los funcionarios públicos (Pierson y Weaver, 1993), un electorado político sin relevancia particular para la coalición de Cardoso”. (Gaetani, 2000, p. 6).

Por outro lado, podemos encontrar no estudo de Silva (2001, p. 137), sobre as características da Central Única dos Trabalhadores (CUT), um outro fator que poderia ser conjugado às explicações dadas por Melo (2002) e Gaetani (2000).

O objetivo do texto de Silva (2001) é questionar o "senso comum” de que a CUT agiria meramente na defesa dos interesses corporativos dos servidores públicos. Diferentemente dessa proposição, o autor argumenta que “o peso quantitativo" dos trabalhadores do setor público no interior da CUT não se traduz automaticamente em domínio dos trabalhadores desse setor no processo de tomada de decisão dentro da organização.

Na verdade, de acordo com Silva (2001), a CUT apresentaria uma grande heterogeneidade de interesses e desse fato decorreriam diversos problemas para alcançar “ações concertadas” no interior do órgão.

O exemplo dado por Silva (2001) para demonstrar essa proposição seria justamente o de que a mobilização e a participação do sindicato cutista nas negociações da reforma administrativa do governo FHC foi inexistente.

A falta de coordenação e mobilização do sindicato cutista na reforma administrativa do governo FHC, verificada por Silva (2001), confirmaria a hipótese do 
autor nesse texto. Ou seja, para Silva (2001), a mobilização da CUT aconteceria apenas quando a reforma atingisse os interesses de todos os seus filiados e não apenas de uma parte deles - como é o caso da reforma administrativa.

"No caso do sindicalismo cutista, por exemplo, verifica-se que a Central encontrou grandes dificuldades para mobilizar categorias econômicas e profissionais que não eram afetadas diretamente por políticas específicas de reforma do Estado, como a reforma administrativa e a quebra do monopólio estatal”. (Silva, 2001, p. 137).

A partir dos argumentos colocados por Silva (2001), poderíamos dizer então que a explicação para o fato das negociações da reforma administrativa não terem sido feitas com a CUT foi resultante de problemas internos à própria organização sindical para coordenar os interesses dos seus filiados a fim de possibilitar uma ação conjunta.

O fracasso das negociações entre as associações de trabalhadores e o MARE em torno da reforma administrativa também é apontado pelo estudo de Cheibub (2000). O estudo do autor sobre as entidades associativas dos funcionários públicos federais (EAs) também afirma que as negociações entre uma parte específica dessas entidades e o MARE fracassaram.

O autor analisa a participação do Fórum das Carreiras Típicas do Estado (FCTE) nas negociações da reforma administrativa. O FCTE foi um grupo de EAs formalizado em 1994 e tinha o objetivo de representar os interesses da "elite do serviço público” nas negociações com o governo federal. (Cheibub, 2000, p. 132).

Quando associamos esse fato à descrição dos objetivos do PDRAE, poderíamos dizer que seria essa a entidade dos servidores públicos que teria uma alta propensão a cooperar com as iniciativas do MARE.

"Poder-se-ia, de antemão, esperar que dessa interação [entre FCTE e MARE] surgisse uma relação de cooperação entre os atores envolvidos, uma vez que o FCTE é composto basicamente por carreiras da elite do serviço público que, na proposta de reforma administrativa do governo, deveriam ser beneficiadas e fortalecidas”. (Cheibub, 2000, p. 131). 
No entanto, ao contrário do que se poderia esperar dessas relações tomadas $a$ priori, houve “fracasso nas conversações” entre o MARE e o FCTE. ${ }^{15}$

Para explicar esse fato, Cheibub (2000, p. 131) - assim como Silva (2001, p. 133) para o caso da CUT - atribuiu um peso importante à dificuldade de coordenação de interesses no interior do FCTE. Além disso, o autor alegou que um fator de ordem mais geral e estrutural foi também responsável pelo "fracasso das conversações” entre governo e o FCTE.

Para Cheibub (2000, p. 131), a "baixa institucionalização dos canais de interação entre governo e EAs” - que caracteriza a estrutura de negociação entre estes dois atores no Brasil - seria um fator importante para a explicação dos rumos que tomaram as negociações entre o FCTE e o MARE no Brasil.

Portanto, as razões, apontadas por Cheibub (2000), para explicar por que não houve negociação entre o FCTE e o MARE são duas: falta de organização interna tanto do FCTE como do governo (no caso, do MARE) - e a "baixa institucionalização dos canais de interação entre governo e EAs” que caracteriza a dinâmica política brasileira.

Em resumo, importaria ressaltar nessa parte do texto as razões pelas quais um dos atores normalmente considerado pelos estudos sobre reforma do Estado como importante, não participou nas negociações do PDRAE. ${ }^{16}$

\footnotetext{
${ }^{15}$ A confirmação dessa afirmação é feita também por Gaetani (2000, p. 7). O autor comparando a experiência de reforma administrativa do Brasil com a experiência dos países pioneiros na implementação de princípios gerenciais na administração pública (Nova Zelândia, Austrália e Reino Unido), alega que os funcionários de carreira tiveram um papel secundário no caso brasileiro enquanto no caso dos outros países desempenharam um "papel-chave na formulação e/ou implementação da reforma".

${ }^{16} \mathrm{O}$ fato da participação dos sindicatos trabalhistas ter sido limitado na negociação não significa, necessariamente, que o papel dessas associações tenha sido inexistente na reforma. Mais à frente, na análise das votações do projeto de reforma administrativa na Câmara dos Deputados, vamos ver que parte dos funcionários públicos (a "elite do funcionalismo") poderia sim ter tido influência nos rumos da reforma administrativa. Isto é, vamos argumentar que existiam condições (o que, evidentemente, não é suficiente para argumentar que algo ocorreu) para suspeitar que os funcionários públicos participaram das votações da reforma administrativa do governo FHC. Especificamente, argumentaremos que o alto apoio dado pelo Partido da Frente Liberal (PFL) à reforma administrativa do governo FHC não foi
} 
Na próxima seção desse trabalho, introduzimos as explicações sobre as negociações da reforma administrativa do governo FHC com um último ator. Diferentemente do que a literatura apontou sobre o papel dos sindicatos dos trabalhadores, os estudos da reforma administrativa do governo FHC apontam que os governadores estaduais foram atores relevantes e decisivos na condução e apoio a esta reforma.

Apresentamos brevemente as razões para a entrada desse grupo de atores nas negociações da reforma administrativa e depois analisaremos no capítulo seguinte (Capítulo II) qual foi a sua influência efetiva na aprovação da reforma administrativa na Câmara dos Deputados.

\section{O Papel dos Governadores}

De acordo com a literatura, o apoio dado pelos governadores à proposta de reforma administrativa do MARE foi fundamental tanto para sua viabilidade política (Gaetani, 2000; Gaetani e Heredia, 2002, p. 14; Melo, 2002, p. 172), como também, para sua aprovação no Congresso (Abrucio e Costa, 1999; Schneider, 2001, p. 9).

A negociação do plano de reforma administrativa com os governadores estaduais ficou a cargo do Ministro da Administração e Reforma do Estado, Bresser Pereira. De acordo com Gaetani e Heredia (2002, p. 14), o argumento utilizado por Bresser para ganhar o apoio desses atores foi o de que a reforma administrativa, que previa a quebra da estabilidade dos funcionários públicos, possibilitaria aos governadores estaduais liberar recursos dos seus orçamentos - que estavam destinados ao pagamento de funcionários públicos.

contraditório com o fato deste partido ter em sua bancada uma parte expressiva de deputados provenientes do funcionalismo público. 
Como a grande maioria dos estados da federação estava gastando mais de $60 \%$ das suas receitas com o pagamento dos seus funcionários públicos ${ }^{17}$, a quebra da estabilidade despertou um grande interesse dos governadores em ver aprovada a reforma administrativa do governo FHC (Abrucio e Costa, 1999, p. 159; Melo, 2002).

Ou seja, uma parte expressiva dos recursos dos estados estava destinada ao pagamento de pessoal e poderia ser liberada, caso essa reforma fosse aprovada. Nesse sentido, os governadores, que tinham pouco espaço para gastar em outras áreas, aumentariam sua liberdade na execução do orçamento. (Gaetani e Heredia, 2002; Melo, 2002, p. 172).

Além disso, pelo fato dos gastos com pagamento de pessoal da administração pública estarem acima dos 60\% da Receita Líquida Corrente (RCL) na maioria dos Estados, os governadores estaduais poderiam enfrentar problemas por estarem descumprindo a Lei Camata. ${ }^{18}$

Gaetani (2000) alega que a aprovação da Lei Camata em 1995 teve uma forte influência sobre a estrutura de incentivos dos governadores direcionando-os a apoiarem a reforma administrativa federal. De acordo com o autor, a aprovação dessa lei fez com que os governadores estaduais passassem a apoiar as medidas que levassem seus governos a alcançar o ajuste de suas contas.

"Pero Bresser suministró una argumentación ah doc, que vinculaba la reforma administrativa con la consolidación del Plan Real y simultáneamente cooptaba el apoyo de los gobernadores al proyecto. Una importante medida subsiguiente al Plan Real fue la Ley Camata, aprobada durante el primer año del gobierno del Cardoso, destinada a disciplinar los gastos estadales. Dados los rasgos federalistas

\footnotetext{
${ }^{17}$ De acordo com os dados de Mora (2002), em 1995 apenas três estados estavam gastando menos de $60 \%$ de suas receitas corrente líquida no pagamento de pessoal, esse número passa para oito em 1996, catorze em 1997 e dezesseis em 1998.

${ }^{18}$ A Lei Camata promulgada em 1995 proíbe que a União, os Estados e os Municípios gastem mais de $60 \%$ de suas respectivas receitas correntes líquidas (receita corrente deduzidas as transferências por participações, constitucionais ou legais) com pessoal ativo e inativo da administração direta e indireta. A lei permite ainda que os governos, que estivessem gastando mais do que o teto definido, teriam o limite de três anos para ajustar as suas contas. A Lei Camata foi revogada em 1999 pela Lei Complementar no. 96, que estabeleceu novos limites para as despesas totais com pessoal. Por fim, esta última lei foi revogada e substituída em 2000 pela “Lei de Responsabilidade Fiscal” (Lei Complementar no. 101). (Rocha e Giuberti, 2004, p. 4-6).
} 
del gobierno brasileño y la relevancia financiera de las economías estadales, el gobierno nacional se encontraba comprometido en la tarea de suprimir los drenajes financieros derivados de las presiones políticas de los gobernadores estadales para cubrir los déficits crônicos. Así, los gobernadores se unieron al equipo económico como aliados del proyecto de Bresser Pereira, porque necesitaban expandir su espacio de maniobra para promover ajustes regionales”. (Gaetani, 2000, p. 6).

Na citação acima, observamos que não foi apenas a promulgação da Lei Camata que incentivou os governadores a apoiarem a reforma administrativa. Esse autor argumenta também que o endividamento dos estados e o esforço do governo federal em ajustar as contas nacionais uniu os governadores à equipe econômica do governo FHC no apoio ao PDRAE e, de maneira mais geral, no apoio às medidas destinadas a sanear as finanças públicas.

Nesse mesmo sentido, Abrucio e Costa (1999) alegam que:

“(...) o governo federal ${ }^{19}$ aproveitou a crise fiscal dos Estados para fazer a seguinte barganha: trocou a renegociação da dívida dos Estados - que discutiremos no próximo capítulo - pela votação com o governo na Emenda da reforma administrativa, especialmente no que se refere à flexibilização da estabilidade". (Abrucio e Costa, 1999, p. 67). ${ }^{20}$

Portanto, podemos identificar até aqui, pelo menos, três motivos interrelacionados para explicar o apoio dos governadores ao PDRAE.

Em resumo, os estudos argumentam que o apoio dos governadores ao PDRAE foi conseguido, pois, de um lado, esse plano previa a quebra da estabilidade dos servidores públicos e isso, por sua vez, possibilitaria aos governadores estaduais (i) liberar recursos dos seus orçamentos e (ii) cumprir a Lei Camata e ajustar as contas dos seus estados.

\footnotetext{
${ }^{19}$ Observe que no ponto em questão (renegociação das dívidas estaduais em troca do apoio à reforma administrativa), seria para o executivo federal como um todo - e não apenas para o MARE e Bresser Pereira - que interessaria o apoio dos governadores ao PDRAE. A observação é importante, na medida em que, conforme descrito por Gaetani e Heredia (2002), a reforma administrativa continuou sendo vista com desconfiança pelos outros ministérios do executivo mesmo após Bresser Pereira ter ganhado o aval do Presidente para levar à frente o processo de reforma.

${ }^{20}$ Essa informação de Abrucio e Costa (1999) é confirmada também por Rocha e Giuberti (2004, p. 5). As autoras alegam que a União, dentro do "Programa de Refinanciamento e Ajuste Fiscal" de 1997, assumiu e refinanciou a dívida mobiliária de todos os Estados brasileiros - exceto Tocantins, Amapá e Distrito Federal. Em troca, os Estados deveriam contribuir com a União com a reforma do Estado e com a introdução de outras medidas para reduzir o gasto público estadual.
} 
Além disso, como levantam Abrucio e Costa (1999), (iii) o apoio ao PDRAE também seria interessante aos governadores estaduais na medida em que o governo federal abriria canais para negociação das dívidas estaduais.

Não bastassem esses três incentivos, Melo (2002, p.172) e Abrucio e Costa (1999, p. 67) indicam ainda um quarto incentivo para os governadores apoiarem o PDRAE. Para eles, a quebra da estabilidade prevista pelo plano de reforma seria interessante também aos governadores estaduais, pois essa medida aumentaria seu poder de patronagem.

Essa estrutura de incentivos seria ainda intensificada por um outro elemento levantado por Abrucio e Costa (1999). A aprovação da emenda da reeleição (para os cargos políticos majoritários) no momento em que a reforma administrativa ainda estava sendo negociada com os governadores estaduais, aumentaria ainda mais os incentivos dos governadores para apoiar a quebra da estabilidade.

A importância desse fato é expressa por Abrucio e Costa (1999) na citação abaixo.

\begin{abstract}
“Além disso, pensando na reeleição os governadores e mesmo os deputados poderiam apoiar a aprovação da flexibilização da estabilidade e só implementá-la no ano seguinte, quando estivessem reeleitos, e tendo o terreno preparado para as modificações essenciais para ajustar as contas públicas como também para redesenhar o mapa da patronagem nos Estados. Assim, a variável tempo juntava 'o útil ao agradável': os governadores e os congressistas ajudavam a aprovar a flexibilização da estabilidade e só utilizariam depois de reeleitos, diminuindo os custos de transição". (Abrucio e Costa, 1999, p. 67-68).
\end{abstract}

Nesse contexto, diversos governos estaduais não só apoiaram o PDRAE, como em alguns casos até se anteciparam à votação da proposta do governo federal, criando seus próprios programas estaduais de reforma da administração pública. (Abrucio e Costa, 1999).

É importante ressaltar que esses programas de reforma administrativa estavam muito mais orientados a diminuir o número de funcionários públicos dos estados do que 
interessados em aplicar os princípios da reforma gerencial, tal como previsto no PDRAE. $^{21}$

No entanto, a despeito da tentativa dos governadores para cortar os gastos das suas respectivas administrações estaduais, houve muita resistência interna nos estados em que foram elaborados planos próprios de reforma administrativa. Em muitos casos, as medidas buscadas pelos governadores ficaram paralisadas ou simplesmente fracassaram. ${ }^{22}$

Entendemos que por esse motivo os governadores estaduais aumentaram ainda mais o seu interesse em ver aprovada a reforma administrativa do governo FHC principalmente, como já foi dito, no que se referia à quebra da estabilidade dos funcionários públicos.

Em suma, de acordo com a literatura (Melo, 2002; Abrucio e Costa, 1999; Gaetani, 2000; Gaetani e Heredia, 2002), podemos perceber que incentivos para os governadores apoiarem a reforma administrativa - em especial, a quebra da estabilidade dos funcionários - não faltaram.

Analisaremos no Capítulo II, a influência efetiva da situação financeira e fiscal dos estados (cumprimento da Lei Camata e endividamento dos Estados) sobre a decisão dos governadores de apoiar a reforma federal.

Entretanto, na próxima parte desse capítulo, continuaremos revisando os argumentos da literatura. Passaremos aos estudos sobre as relações entre executivo e legislativo no Brasil e sobre a influência dos governadores estaduais no processo decisório nacional.

\footnotetext{
21 “A reforma em outros estados”, FSP, 16/01/96; “Alencar quer demitir até 68 mil servidores”, FSP, 11/01/96; "Governo mineiro demite 32 mil servidores”, FSP, 29/02/96; "Cortes levam petistas do ES a rompimento com governador", FSP, 05/07/96; "Governo de SC anuncia reforma administrativa”, FSP, 11/01/96; "Demissões começam no sul”, FSP, 18/04/96.

22 "Executiva do PT apóia Vitor Buiz no ES“, FSP, 11/06/96; "Entenda a crise no ES”, FSP, 10/12/96; "Governador de SC vai ao STF por reformas", FSP, 12/01/96; "Reforma sofre derrotas na Assembléia e na Justiça”, FSP, 16/01/96; “Justiça concede três liminares contra a reforma”, FSP, 18/01/96.
} 


\section{Tramitação Legislativa: emendas constitucionais e as instituições políticas no Brasil}

A reforma administrativa do governo FHC foi uma iniciativa que visava alterar a Constituição Federal por meio de Emendas Constitucionais (Projeto de Emenda Constitucional 173 - PEC/173). (Gaetani, 2000; Melo, 2002). Nesse sentido, havia regras/exigências que deveriam ser seguidas durante a sua tramitação. ${ }^{23}$

As exigências para a aprovação de emendas constitucionais são maiores vis-à-vis outras matérias votadas no legislativo ${ }^{24}$. Dentre todas as exigências, seria pertinente ressaltar duas, quais sejam, a de que além do proponente ter que (i) conseguir maioria qualificada para a sua aprovação (60\% dos parlamentares da Câmara e do Senado); (ii) o projeto de emenda constitucional torna visível (por meio da exigência de votação nominal) a contribuição que cada um dos parlamentares dá para a sua aprovação.

Na medida em que a reforma administrativa é um projeto que acarreta custos concentrados para determinados atores - no caso, especialmente, os funcionários públicos de médio e baixo escalão -, a visibilidade dos votos dos parlamentares poderia tornar-se um grande impedimento para a sua aprovação.

No caso de votação de emendas constitucionais, este efeito (visibilidade da contribuição) pode ser intensificado ainda pelo fato da legislação prever a possibilidade de requerimento de destaques de votação em separado (DVS) pelos parlamentares.

\footnotetext{
${ }^{23}$ Nos termos de Diermeier e Krehbiel (2002), emendas constitucionais seriam, portanto, um processo de alteração de regras/instituições que são reguladas por outras instituições.

${ }^{24}$ Para emendar a Constituição brasileira, os projetos devem primeiramente passar por duas instâncias. Na Comissão de Constituição e Justiça e de Redação (CCJR) haverá a deliberação se a proposta de emenda é admissível ou não para ir ao plenário. E após passar pela CCJR, a proposta será encaminhada a uma Comissão Especial (CE), formada pelos deputados, onde será analisado o mérito do projeto e onde poderão ser feitas emendas a este. Para fazerem emendas ao projeto inicial, os deputados da comissão terão que apresentar as emendas nas dez primeiras sessões e obterem apoio de pelo menos um terço da composição da câmara por emenda apresentada à proposta original. Só após a passagem por essas duas comissões o projeto de emenda constitucional (PEC) será levado ao plenário da Câmara dos Deputados e, posteriormente, ao Senado Federal. Para ser aprovado, é necessário que 3/5 (60\%) dos parlamentares aprovem o projeto (quorum qualificado) em dois turnos nas duas casas, sendo que a votação do projeto é nominal. (Câmara do Deputados, 2004).
} 
Este artifício, portanto, aumentaria ainda mais a possibilidade do eleitor identificar a responsabilidade de determinado parlamentar na votação de uma matéria impopular ou controversa. (Melo, 2002). ${ }^{25}$

Portanto, devido a estas características do processo de emendas à constituição, em especial, poderíamos esperar que o projeto de reforma administrativa tivesse grandes dificuldades para aprovação.

Associadas a essas dificuldades, existem ainda outros argumentos sobre as instituições políticas brasileiras que diminuiriam ainda mais a probabilidade de uma reforma (com as características da reforma administrativa do MARE) ser aprovada no legislativo brasileiro.

Diversos cientistas políticos ${ }^{26}$ argumentam que a alta fragmentação do sistema político brasileiro é um problema decisivo para aprovação de matérias no legislativo. Esses autores alegam que as instituições que vigoram no sistema político brasileiro impediriam o alcance de um razoável grau de governabilidade no país.

A primeira grande dificuldade apontada por essa literatura seria decorrente do sistema político do país ser presidencialista. Como no presidencialismo os mandatos do executivo e do legislativo são independentes, há uma alta probabilidade de se obter um executivo sem sustentação parlamentar.

Conforme descrito por Santos (1997, p. 3), essa independência de mandatos tornaria também as funções dos poderes executivo e legislativo concorrentes - e, não cooperativos - na formação de leis.

\footnotetext{
${ }^{25}$ A importância da visibilidade no processo de reformas, que acarretam custos concentrados para determinados setores da sociedade, é exposta por Pierson (1996; 2001).

${ }^{26}$ Alguns dos autores representativos desta corrente são: Barry Ames, Bolívar Lamounier, Scott Mainwaring e Fernando Abrucio e David Samuels - no caso do argumento sobre a influência do federalismo na lealdade partidária. (Arretche, 2002; Santos, 1997; Figueiredo \& Limongi, 1999; Nicolau, 2000; Palermo, 2000; Melo, 2002; Cheibub, Przeworski \& Saiegh, 2002).
} 
No curto prazo, como sumariza Palermo (2000, p. 8), o presidente poderia concentrar poder decisório e utilizar as medidas provisórias para driblar a paralisia que estivesse enfrentando no legislativo. Contudo, essa "solução" seria instável, na medida em que o parlamento retaliaria o executivo nos períodos posteriores por ter usurpado seu poder decisório.

Em segundo lugar, os autores, que adotam essa perspectiva, alegam que o executivo federal enfrentaria dificuldades para governar por meio de coalizões firmadas com os partidos. Essas dificuldades seriam decorrentes, sobretudo, do incentivo que as regras eleitorais dão ao comportamento do parlamentar.

As eleições para o legislativo federal no Brasil obedecem à regra de representação proporcional com lista aberta (RPLA). O sistema de representação proporcional garante representação política às minorias e gera multipartidarismo. Conseqüentemente, haveria uma baixa probabilidade do presidente eleito deter a maioria das cadeiras no Congresso, bem como haveria dificuldades daquele ator (executivo) costurar uma coalizão que pudesse atender os diversos interesses representados no Congresso Nacional.

No caso da lista aberta, os autores alegam que esta incentivaria o comportamento individualista do parlamentar em detrimento de um comportamento comprometido com as lideranças partidárias e com o fortalecimento do seu partido.

Portanto, a RPLA diminuiria o poder dos líderes partidários no controle das suas bancadas e, conseqüentemente, impossibilitaria o executivo de firmar coalizões partidárias que fossem efetivas e estáveis.

Somados a esses fatores, há ainda outros autores que apontam o federalismo como uma variável importante para explicar a suposta ingovernabilidade do país. O federalismo diminuiria o grau de governabilidade do país por duas razões principais. 
De um lado, pelo fato dos governos subnacionais possuírem autonomia política, as dificuldades do governo central para coordenar (ou alterar) as políticas públicas no país seriam aumentadas.

De acordo com a literatura pertinente, essa seria a influência do federalismo no plano das "relações verticais", ou seja, haveria uma baixa governabilidade no país em razão das negociações entre as diversas esferas subnacionais e a União serem nãohierarquizadas.

Além desse efeito do federalismo sobre a governabilidade nacional, haveria também dificuldades decorrentes do fato dos interesses dos estados da federação estarem representados no interior do legislativo federal.

Ou seja, os parlamentares do legislativo federal são eleitos nos Estados Federativos e têm como função representar os interesses de suas respectivas bases eleitorais no âmbito federal. Portanto, dentro dessa perspectiva, eles seriam mais leais às suas bases estaduais do que aos partidos aos quais pertencem.
"Isto porque o atual sistema eleitoral acirra a competição entre os candidatos do próprio partido e estar vinculado a uma estrutura poderosa como são as máquinas públicas estaduais eleva as chances de vitória eleitoral”. (Abrucio e Samuels, 1997, p. 152).

Nesse sentido, para que o presidente conseguisse aprovar seus projetos no legislativo seria necessário contar com o apoio não apenas dos líderes partidários, mas principalmente dos governadores que orientariam os deputados federais, eleitos por seus Estados, nas votações do legislativo.

“As propostas de reforma enviadas pelo Governo Federal ao Congresso sofrem, quase sempre, pressões regionais. Isso se dá basicamente porque os parlamentares respondem mais às lealdades estaduais do que às lealdades partidárias”. (Abrucio e Samuels, 1997 apud Abrucio e Costa, 1999, p. 14).

Para tanto, seria necessário que o presidente atendesse às demandas dos estados correspondentes para conseguir os votos dos parlamentares. Abrucio e Costa (1999) 
resumem o "pacto de benefício mútuo” que supostamente existiria entre parlamentares atuantes na esfera federal e os governadores estaduais:

"Expliquemos melhor. Os governadores têm grande influência sobre o comportamento dos congressistas, mas isso somente acontece porque há um pacto de benefício mútuo: os parlamentares votam com os governadores contanto que os chefes dos Executivos estaduais os auxiliem a manter as suas bases eleitorais, principalmente de base regional. Um dos principais instrumentos para selar esta aliança é a patronagem, ou seja, a distribuição dos cargos públicos para os correligionários e cabos eleitorais dos congressistas”. (Abrucio e Costa, 1999, p. $66) .{ }^{27}$

Em resumo, de acordo com essa literatura, o executivo federal, que pretendesse alterar o status quo, enfrentaria dificuldades derivadas das mais variadas fontes, sobretudo, se a alteração pretendida por esse ator (executivo federal) fosse uma tentativa de emendar a constituição - tal como foi o caso da reforma administrativa do governo FHC.

“É interessante notar que o Brasil 'padece' de quase todas as 'patologias' institucionais identificadas pela literatura como fatores responsáveis pela elevação do custo de governar: é um sistema presidencialista; uma federação; possui regras eleitorais que combinam sistema de lista aberta com representação proporcional; tem um sistema multipartidário com partidos políticos considerados débeis na arena eleitoral; e tem sido governado por uma ampla coalizão”. (Pereira e Mueller, 2002, p. 266).

Dentre todos esses argumentos, o que importaria ressaltar para os propósitos do nosso trabalho é que, de acordo com essa literatura, os partidos políticos teriam muita pouca importância nas votações e os governadores estaduais seriam atores bastante relevantes nas votações dentro do Congresso Nacional.

Diferentemente, entretanto, outros autores indicaram que no Brasil existiriam instituições/regras no interior do legislativo (arena parlamentar) que ajudariam o

\footnotetext{
${ }^{27}$ No caso da reforma administrativa, Abrucio e Costa (1999, p. 67) alegam que esse pacto foi quebrado pelos governadores interessados em flexibilizar a estabilidade dos funcionários públicos estaduais e ajustar as contas públicas dos seus Estados - conforme foi apresentado anteriormente. De acordo com esses autores então, os governadores estaduais teriam se colocado a favor da flexibilização da estabilidade e os congressistas contra. No entanto, para esses dois autores, esse conflito de posições foi resolvido em favor dos governadores e a despeito das posições assumidas pelos parlamentares do Congresso Nacional. Nesse sentido, eles colocam que: "Essa mobilização final dos governadores foi fundamental para a aprovação da reforma administrativa em seus tópicos mais vinculados ao ajuste das contas públicas”. (Melo, 1998: 10-12 apud Abrucio e Costa, 1999, p. 68). Ou seja, de acordo com esses autores,
} 
executivo na tramitação das suas matérias - e, portanto, favoreceriam a governabilidade do país.

De acordo com os autores que adotam essa perspectiva, as regras que regulam os trabalhos no interior do legislativo não teriam sido levadas em conta pela literatura que alega que o Brasil tende a ter baixa governabilidade. (Figueiredo e Limongi, 1999; Pereira e Mueller, 2003; Santos, 1997, p. 9; Santos, 2002; Palermo, 2000).

Para esses autores, o (i) alto poder de agenda do executivo e seu direito à exclusividade da iniciativa em matérias relativas ao orçamento, às questões tributárias e também as relacionadas à organização administrativa do Estado $^{28}$; (ii) a alta centralização dos trabalhos do Congresso nas mãos dos líderes partidários e (iii) o controle sobre os recursos financeiros pelo executivo (Pereira e Mueller, 2002) seriam fatores que diminuiriam a possibilidade dos parlamentares se comportarem individualmente.

De acordo com essa literatura, as alternativas de comportamento que os parlamentares teriam se resumiriam ao fato deles serem forçados a cooperar com os seus partidos. Pois, a única saída para que eles conseguissem barganhar algo com o executivo - que detém o monopólio dos recursos - seria coletivamente, ou seja, através do seu partido político. (Santos, 2002, p. 242).

no caso da reforma administrativa, os governadores ganharam a "batalha” com os congressistas nas votações e foram responsáveis pela aprovação da reforma.

${ }^{28}$ A importância desse atributo é apresentada pelas análises formais dos estudos da ciência política estadunidense. Do ponto de vista formal, o executivo brasileiro nas matérias orçamentárias, tributárias e administrativas deteria, portanto, o que é denominado na literatura de estudos da relação ExecutivoLegislativo como gate keeping power. Isto é, nestas matérias, o executivo teria a opção de "engavetar” ou abandonar o projeto, caso antevisse dificuldades em sua aprovação no Legislativo. (Morrow, 1994, p. 133; Santos, 1997, p. 6-9). Dentro deste raciocínio, o Executivo poderia agir através de backwards induction - quando pudesse prever (ambiente com informação perfeita) dificuldades a respeito da aprovação do projeto. Para tanto, bastaria ao Executivo (i) considerar o ponto em que se encontra o status quo em determinada matéria, (ii) compará-lo com qual o desejo (previamente conhecido) que a maioria do Legislativo tem sobre esta matéria e, finalmente, (iii) ver se este ponto definido pela preferência da maioria do Legislativo melhoraria ou não a sua (do Executivo) utilidade em relação ao status quo. 
Na medida em que o comportamento do parlamentar seria na direção de fortalecer e seguir as orientações do seu partido, haveria então a possibilidade do executivo governar por meio de coalizões partidárias estáveis.

Nesse contexto, o executivo negociaria com as lideranças partidárias que, por sua vez, teriam poder suficiente para coordenar as suas respectivas bancadas nas votações.

Portanto, conforme resumido por Palermo (2000), para esse segundo grupo de autores, o executivo conseguiria a “cooperação forçada” do parlamento e, conseqüentemente, desfrutaria de um considerável grau de governabilidade.

Em resumo, vemos que as interpretações sobre as relações entre executivolegislativo no Brasil apresentam consideráveis divergências. Nesse sentido, no capítulo II analisaremos qual dos dois conjuntos de argumentos é mais adequado para explicar o caso das votações da reforma administrativa do governo FHC. 


\section{Capítulo II - Análise da Votação da Reforma Administrativa do Governo FHC: o papel partidos políticos e dos governadores estaduais}

Nesse capítulo, testamos as proposições expostas no primeiro capítulo. A análise será direcionada aos argumentos sobre a participação dos governadores estaduais na aprovação da reforma administrativa do governo FHC e também sobre os estudos mais abrangentes das instituições políticas no Brasil.

Nesse sentido, pretendemos investigar nesse capítulo basicamente três proposições identificadas nos estudos. Verificamos, primeiramente, qual foi o papel dos partidos políticos na votação da reforma administrativa.

Além disso, no que se refere aos governadores estaduais, verificaremos se seu apoio ao PDRAE foi de fato derivado da situação fiscal e financeira de seus respectivos estados e, por fim, qual foi sua contribuição efetiva na votação da reforma administrativa.

Nesse contexto, dividiremos esse capítulo analítico em três partes principais. Na primeira parte serão expostos o material e os instrumentos/indicadores utilizados para analisar a votação da reforma administrativa. Em seguida, verificaremos a disciplina partidária dos parlamentares na votação da reforma administrativa. E, por fim, analisamos as proposições da literatura sobre o papel dos governadores estaduais na votação da reforma administrativa. 


\section{Material e Método para analisar as votações da reforma administrativa}

Para analisar a votação da reforma administrativa do governo FHC, utilizamos como material os dados do "Banco de Dados Legislativos” elaborado pelo CEBRAP. ${ }^{29}$

No "Banco de Dados Legislativos" do CEBRAP, encontramos 50 votações nominais referentes ao Projeto de Emenda Constitucional 173 (PEC 173) na Câmara dos Deputados. Todas ocorreram no ano de 1997, na 50 Legislatura, na qual havia um total de 513 cadeiras.

Das cinqüenta votações nominais encontradas, excluímos as votações em que houve um elevado grau de consenso (13). Para tanto, nos apoiamos nos argumentos dos autores que realizaram estudos sobre as votações nominais no legislativo brasileiro (Nicolau, 2000, p. 3; Figueiredo e Limongi, 1999).

Os autores em questão incluem nas suas análises apenas os votos que “dividem minimamente o plenário”. Esse procedimento é realizado porque a inclusão de votações com elevado grau de consenso tende a sobredimensionar a taxa média de disciplina dos parlamentares.

Nicolau (2000) alega, entretanto, que não existe um critério único a ser adotado para selecionar as votações. Nesse sentido, optamos por excluir as votações em que, no mínimo, 95\% do plenário votou ou “sim” ou “não”.

Para excluir essas votações consensuais, consideramos no cálculo apenas os deputados que estavam presentes na votação. Optamos por excluir as faltas, uma vez que encontramos votações onde $80 \%$ do total da Câmara dos Deputados votou em uma das duas opções - p. ex., "sim” - e alternativa oposta ao voto dos $80 \%$ dos

\footnotetext{
${ }^{29}$ LIMONGI, Fernando \& FIGUEIREDO, Argelina Cheibub. "Votações nominais na Câmara dos deputados (1989-1999)”. Banco de Dados Legislativos, CEBRAP.
} 
deputados (no exemplo, “não”) não foi feita por sequer um único deputado - os 20\% restante nesses casos ou se abstiveram ou faltaram da votação.

Ou seja, nesses casos, se considerássemos todos os 513 deputados da Câmara e não apenas os presentes, a votação em questão seria incluída na análise - quando, na verdade, ela é consensual e deveria ser excluída para não superestimar a taxa de disciplina.

Enfim, com esse procedimento, as cinqüenta votações referentes ao PEC 173 foram reduzidas para trinta e sete (37) votações nominais. Portanto, serão essas trinta e sete votações, que “dividiram minimamente o plenário”, que serão analisadas nesse trabalho.

Nestas votações nominais consideramos para o cálculo da disciplina partidária, os sete maiores partidos na Câmara dos Deputados (PPB, PFL, PTB, PMDB, PSDB, PDT e PT) no período da votação da reforma administrativa (1997). Juntos eles detiveram ao longo destas 37 votações, em média, 472 cadeiras das 513 na Câmara dos Deputados, ou seja, representaram 92\% das cadeiras da Câmara.

\section{Tabela 1}

Bancada dos sete partidos durante as 37 votações do PEC 173 em 1997

\begin{tabular}{|l|r|r|r|r|}
\hline & Mínimo & Máximo & Média & Desvio-Padrão \\
\hline PPB & 77 & 80 & 79 &, 866 \\
PFL & 102 & 110 & 106 & 2,131 \\
PTB & 22 & 23 & 23 &, 280 \\
PMDB & 83 & 98 & 94 & 5,027 \\
PSDB & 94 & 98 & 96 & 1,204 \\
PDT & 22 & 23 & 23 &, 280 \\
PT & 50 & 51 & 51 &, 422 \\
TOTAL & 465 & 475 & 472 & 3,485 \\
\hline
\end{tabular}

a. Fonte: Banco de Dados Legislativos, CEBRAP. 
Os partidos que faziam parte da coalizão ampliada ${ }^{30}$ (PSDB, PFL, PTB, PMDB, PPB) do governo FHC detiveram, em média, nestas 37 votações, 398 deputados - isto é, 77,58\% do total de cadeiras da Câmara dos Deputados (513).

Como são os necessários 308 votos (60\% dos parlamentares) para aprovar um projeto de emenda constitucional, observa-se que o executivo - caso pudesse contar com a disciplina dos partidos de sua base - detinha maioria folgada para a aprovação do PEC 173 na Câmara dos Deputados.

A disciplina partidária foi calculada através do percentual de parlamentares que seguiu a indicação do líder do seu partido para votar. Nas ocasiões em que o líder do partido indicou voto favorável à matéria (sim), consideraremos como voto indisciplinado, além dos votos contrários à indicação do líder (não), as abstenções e as faltas. No caso do líder do partido ter indicado voto contrário (não), desconsideraremos as abstenções e as faltas para o cálculo da disciplina partidária. ${ }^{31}$

A disciplina média dos sete maiores partidos da Câmara foi calculada excluindose da análise as votações em que o líder de determinado partido (i) liberou a sua bancada, (ii) obstruiu ou (iii) não havia declaração de votos no "Banco de Dados Legislativos” do CEBRAP.

Neste sentido, analisamos então a disciplina média de cada um dos partidos durante as votações da reforma administrativa. Além disso, calculamos também a média

\footnotetext{
${ }^{30}$ Figueiredo e Limongi (1999, p. 201) utilizam os termos coalizão eleitoral para indicar os partidos (PFL, PTB e PSDB) que já apoiavam FHC na candidatura em 1994 e coalizão ampliada quando são incluídos na coalizão eleitoral o PPB e o PMDB, os quais começaram a fazer parte do governo após FHC ter sido eleito.

${ }^{31}$ Nicolau (2000, p. 15) chama este índice, utilizado também por Figueiredo e Limongi (1999), de índice de fidelidade à posição do líder do partido. Este índice "é calculado, para cada votação, dividindo-se o total deputados de cada partido que votaram conforme a indicação do líder pelo total de deputados desse partido que compareceram para votar (ou sobre o total da bancada)". Entretanto, a exemplo de Figueiredo e Limongi (1999, p. 215), ponderamos esse índice ao considerar as "abstenções" e as "faltas" como votos indisciplinados nos casos em que o líder do partido indicou voto "sim", pois, intuitivamente, os deputados podem faltar ou se abster da votação para não contrariar explicitamente o líder do seu partido. Por outro lado, nos casos em que o líder indicou voto "não", tanto as "abstenções" como as "faltas" não podem ser consideradas a priori nem como votos disciplinados nem, tampouco, como indisciplinados. Portanto, nesses casos desconsideramos as “faltas” e as “abstenções” dos cálculos.
} 
de disciplina partidária para os sete partidos conjuntamente a fim de obter uma aproximação do grau de disciplina partidária que vigorou na Câmara dos Deputados como um todo nestas votações.

Entendemos que para obter essa aproximação da disciplina partidária da Câmara dos Deputados como um todo, seria necessário ponderar os valores da disciplina dos partidos. Pois, conforme vimos acima (Tabela 1), os sete partidos não detinham partes iguais das 472 cadeiras.

Nesse sentido, multiplicamos a disciplina média de cada partido com o valor resultante da divisão da bancada média deste partido sobre o total da bancada média considerada aqui (472 e não 513 deputados).

Por exemplo, no caso do PPB, o cálculo foi o seguinte: disciplina média do PPB (74,04\%) x [bancada média do PPB (79) / bancada média total $(472)$ ] = 12,39 Calculamos os valores para cada um dos sete partidos e somamos todos estes valores obtendo a média ponderada de disciplina na Câmara dos Deputados durante a votação da reforma administrativa.

Após a análise da disciplina partidária na reforma administrativa, passaremos nesse mesmo capítulo à análise do papel dos governadores estaduais na votação da reforma administrativa.

Verificaremos, especificamente, se uma das condições fundamentais para que os governadores pudessem influenciar a votação do PDRAE foi atendida. Ou seja, analisamos os dados das votações para verificar se houve um grau de unidade/coesão razoável entre os deputados federais eleitos por um mesmo estado. ${ }^{32}$

\footnotetext{
${ }^{32} \mathrm{O}$ ideal para testar a lealdade dos deputados federais em relação ao governo do Estado pelo qual ele foi eleito seria adotar o mesmo índice utilizado para calcular a disciplina partidária - i. e., índice de fidelidade à posição do líder partidário (no caso, fidelidade à posição do governador). Contudo, não conseguimos encontrar os dados que indicassem a preferência de cada um dos 27 governadores estaduais para cada uma das 37 votações.
} 
Portanto, consideramos que para que os governadores estaduais pudessem influenciar decisivamente as votações da reforma administrativa seria necessário, antes de tudo, que os “seus” deputados federais votassem com um razoável grau de unidade.

Para tanto, utilizamos o índice de unidade (coesão) descrito por Nicolau (2000, nota de fim 12) para calcular se houve unidade entre os deputados eleitos por um mesmo estado nas votações da reforma administrativa. Esse índice é calculado através da divisão do total de votos do lado majoritário pelo total de membros da bancada - no caso, estadual - em uma determinada votação.

Entretanto, o índice de unidade - tal como descrito por Nicolau (2000, nota de fim 12) - não indica qualquer procedimento a ser adotado para classificar as "faltas” e “abstenções” nas votações. Como as “faltas” e as “abstenções” representam um número considerável nas votações, a opção por descartá-las dos cálculos subdimensionaria o índice de unidade, dado que o denominador do índice é composto pelo total de membros da bancada - e não apenas pelos deputados presentes nas votações.

Conseqüentemente, a inclusão das “faltas” e “abstenções” nos cálculos da coesão da bancada estadual se torna um problema a ser solucionado. Para resolver esse problema, analisamos os efeitos que as “faltas” e as “abstenções” têm sobre as votações.

Quando a maioria dos deputados se organiza para votar “sim” em uma matéria, o deputado, que “falta” ou se “abstém” da votação, dificulta a satisfação das preferências deste coletivo e, portanto, o efeito da sua "falta” ou “abstenção" na votação é equivalente ao voto “não” - voto que diminui a coesão.

Por outro lado, quando a maioria dos deputados se organiza para votar “não”, o deputado, que “falta” ou se “abstém” da votação, não dificulta a satisfação das 
preferências deste coletivo pelo fato desta não precisar que o deputado manifeste a sua opção de voto.

Ora, no caso da maioria optar pelo voto "não", o efeito da "falta” ou da “abstenção” do deputado contribui, em última instância, para que a preferência do coletivo seja satisfeita, pois a conseqüência da "falta” ou "abstenção” do deputado na votação prejudica o grupo minoritário, que busca assegurar maioria em torno do “sim”, e favorece o grupo majoritário, que deseja "barrar" a matéria. Portanto, as "faltas” e “abstenções” também serão consideradas nesse caso como voto “não”.

Em suma, para todas as situações - tanto quando a maioria votou "sim" como quando a maioria votou “não” - as “abstenções” e as “faltas” foram consideradas como voto "não” no cálculo do índice de unidade das bancadas estaduais.

Nesse sentido, (i) como as "faltas” e "abstenções” foram incorporadas aos votos “não” - e, portanto, existem agora apenas duas opções de voto (ou “sim” ou “não”) - e (ii) como consideramos para cálculo do índice de unidade, o lado com maior número de votos entre estas duas opções; o índice de unidade das bancadas estaduais varia somente no intervalo de $50 \%$ a $100 \%$ de unidade.

Conseqüentemente, a partir desses cálculos, é possível perceber que o índice de unidade - que varia entre $50 \%$ e $100 \%$ - tende a ser maior que o índice de fidelidade do partido à indicação do seu líder - que pode variar entre $0 \%$ a $100 \%$.

Após calcularmos os índices de unidade estadual para cada uma das 37 votações em cada um dos estados, somamos todos os 37 índices obtidos e os dividimos por este valor (37). Isso nos forneceu a média de coesão de cada uma das unidades federativas nas 37 votações.

Após obtermos a média de coesão para cada uma das 27 unidades federativas, calculamos, por fim, a média ponderada de coesão nos estados brasileiros - através 
do mesmo procedimento que adotamos para o caso da disciplina partidária da Câmara dos Deputados.

Resta, por fim, apontar um último indicador utilizado para a análise da influência dos partidos políticos e dos governadores estaduais na votação da reforma administrativa do governo FHC.

A dispersão tanto do grau de disciplina partidária como da coesão da bancada estadual ao longo das votações foi analisada através de um indicador. Apenas o valor do desvio-padrão da disciplina ou da coesão não nos oferecia uma medida exata que permitisse a comparação da dispersão da disciplina partidária e da coesão estadual.

O valor do desvio-padrão da disciplina de um partido que detém a maior média de disciplina na Câmara tende a ser maior que o desvio-padrão dos outros partidos. Uma vez que, como a média de disciplina é elevada nesse partido, os valores da disciplina de cada uma das votações da reforma administrativa tendem, por definição, a sê-lo também.

Nesse sentido, uma relativa distância da disciplina de uma determinada votação em relação à média de disciplina partidária pode ser traduzida em uma grande distância justamente pelo fato de estarmos lidando com valores de grande magnitude.

Portanto, construímos o Indicador 1 (e o Indicador 2 para análise da dispersão da coesão da bancada estadual) - i. e., desvio-padrão dividido pela média da disciplina partidária (ou coesão média da bancada estadual) - para ponderar o desvio-padrão encontrado e poder comparar a dispersão da disciplina entre os sete partidos em questão (ou entre as vinte e sete bancadas estaduais). ${ }^{33}$

\footnotetext{
${ }^{33}$ Agradeço ao Prof. Dr. Eduardo Marques por ter feito a sugestão dessa relação - e outras que serão apresentadas abaixo - durante a qualificação desse texto. A utilidade do Indicador 1, sugerida por Marques, poderá ser vista na comparação entre as dispersões da disciplina do PTB e PPB na Tabela 3 mais abaixo. Ou seja, embora o PTB apresente desvio-padrão da disciplina $(13,66)$ maior que o PPB $(12,76)$, vemos que se ponderarmos esse valor com a disciplina média do partido (Indicador 1), a dispersão da disciplina no PTB $(0,1655)$ se torna menor que a do PPB $(0,1723)$, uma vez que a disciplina média daquele partido (PTB) é consideravelmente maior (82,55\%) do que a deste (74,04\%).
} 
Descritos então os procedimentos utilizados para analisar a disciplina partidária e a coesão da bancada estadual, começaremos a análise empírica com a descrição da introdução do Projeto de Emenda Constitucional da reforma administrativa (PEC/173) na Comissão de Constituição, Justiça e Redação da Câmara dos Deputados (CCJR) e a sua passagem posterior à Comissão Especial (CE) - formada para analisar o projeto de emenda constitucional.

Após essa breve descrição, analisaremos - levando em conta os dois conjuntos de explicações sobre as instituições políticas brasileiras - o grau de dificuldade que o executivo enfrentou para aprovar o seu projeto de emenda constitucional e, particularmente quais dentre os dois conjuntos de atores foram mais decisivos para o sucesso do executivo na arena parlamentar.

Verificamos o grau de disciplina partidária dos parlamentares dos sete grandes partidos (PPB; PFL; PTB; PMDB; PSDB; PDT; PT) envolvidos nas votações e se esta disciplina - ou melhor, sua possível falta - representou um problema para executivo.

Além disso, analisaremos mais à frente - levando em conta tanto esses argumentos sobre as instituições políticas brasileiras, assim como aqueles especificamente relacionados à reforma administrativa - se é possível (i) deduzir o apoio dos governadores ao PDRAE da situação fiscal e financeira dos seus estados e (ii) se é possível atribuir aos governadores estaduais um papel relevante na aprovação da emenda constitucional da reforma administrativa do governo FHC.

\section{Tramitação do PEC/173 nas Comissões do Congresso}

$\mathrm{Na}$ CCJR, foram postas em votação sete emendas que discutiam a constitucionalidade de alguns pontos da proposta de reforma administrativa do governo. Nestas, o governo saiu vitorioso em metade delas (3) e foi derrotado em outras três, 
sendo que uma das emendas foi retirada pelo relator por apelo unânime dos partidos. (Melo, 2002, p. 161).

Passado o projeto para a Comissão Especial, foram apresentadas 60 emendas ao projeto original, sendo que 40 delas foram incorporadas. Destas, de acordo com Melo (2002), o ponto mais controverso foi o que versava sobre a estabilidade do servidor público.

Na verdade, a estabilidade do servidor - ao lado da possibilidade dos estados e dos municípios fixarem subtetos para remuneração dos seus funcionários e também da fixação de tetos para a remuneração de todos os servidores do Estado foi o ponto da reforma administrativa no qual houve mais debate e divisão entre os deputados.

Passaremos então à análise das votações do PEC 173 na Câmara dos Deputados em 1997 e, adicionalmente, veremos como esses pontos controversos foram resolvidos.

Analisaremos também o grau de disciplina dos partidos e, posteriormente, verificaremos se o grau de disciplina encontrado representou um obstáculo importante para o executivo aprovar o PEC 173.

\section{Disciplina Partidária na Câmara dos Deputados}

Das 37 votações, apenas seis foram referentes a matérias procedimentais - todas apresentadas pelos partidos de oposição (PT, PDT e PSB) -, tendo o governo ganho todas as seis. Ou seja, aproximadamente $16 \%$ das votações foram relativas às regras que regulariam os encaminhamentos da votação do PEC 173. Portanto, a grande maioria das votações estava relacionada a matérias substantivas (84\%).

Feitas essas considerações iniciais, apresentamos abaixo (na Tabela 2) as taxas de disciplina partidária dos sete partidos considerados nesse trabalho. 


\section{Tabela 2}

Disciplina partidária na votação da PEC 173/97 noș sete maiores partidos da Câmara dos Deputados

\begin{tabular}{|l|r|r|r|r|r|}
\hline & $\begin{array}{c}\text { Número de } \\
\text { votações } \\
\text { consideradas }\end{array}$ & $\begin{array}{c}\text { Disciplina } \\
\text { Mínima }\end{array}$ & $\begin{array}{c}\text { Disciplina } \\
\text { Máxima }\end{array}$ & $\begin{array}{c}\text { Disciplina } \\
\text { Média }\end{array}$ & Desvio-Padrão \\
\hline PPB & 33 & $47,44 \%$ & $95,24 \%$ & $74,04 \%$ &, 1276 \\
PFL & 34 & $68,87 \%$ & $100,00 \%$ & $90,70 \%$ &, 0860 \\
PTB & 33 & $39,13 \%$ & $100,00 \%$ & $82,55 \%$ &, 1366 \\
PMDB & 36 & $48,15 \%$ & $96,20 \%$ & $77,58 \%$ &, 1149 \\
PSDB & 34 & $57,89 \%$ & $100,00 \%$ & $88,52 \%$ &, 1099 \\
PDT & 31 & $21,74 \%$ & $100,00 \%$ & $90,55 \%$ &, 1591 \\
PT & 32 & $66,67 \%$ & $100,00 \%$ & $94,53 \%$ &, 0817 \\
\hline
\end{tabular}

a. Banco de Dados Legislativos, Cebrap

b. Foram excluídos os casos em que o líder do partido liberou a bancada, obstruiu ou os casos em que não há declaração de voto do líder.

A partir da Tabela 2, podemos separar os sete partidos em três grandes grupos de acordo com o grau de disciplina média. Em um primeiro grupo, colocamos os partidos que tiveram, em média, maior proporção de votos disciplinados ao longo das votações do PEC 173. Os partidos deste grupo são: o PT (94,53\%) seguido do PFL $(90,7 \%)$ e do PDT $(90,55 \%)$.

Dentro desse grupo de partidos, é importante observar que embora o PDT tenha uma grande média de votos disciplinados (90,55\%), fica a dúvida se esta média é representativa. Uma vez que, a variação média (desvio-padrão) da disciplina dentro deste partido é a maior dentre todos os partidos considerados.

Embora o número de votações consideradas para o cálculo da disciplina do PDT tenha sido o menor dentre todos os partidos (31 votações), o desvio-padrão do percentual de votos disciplinados é de 0,1591 (15,91\%), em que a taxa de disciplina varia no intervalo de um mínimo de 21,74\% a 90,55\%. 
Contudo, tal como foi colocado na parte anterior referente ao material e método utilizados na análise, apenas o valor do desvio-padrão da disciplina não nos oferece uma medida que permita a comparação da dispersão entre os sete partidos selecionados.

Construímos, portanto, o Indicador 1 - i. e., desvio-padrão dividido pela média da disciplina partidária - para ponderar o desvio-padrão encontrado e poder comparar a dispersão da disciplina entre os sete partidos em questão.

\section{Tabela 3}

\begin{tabular}{cccc}
\hline Partido & $\begin{array}{c}\text { Disciplina } \\
\text { Média (\%) }\end{array}$ & $\begin{array}{c}\text { Desvio- } \\
\text { Padrão (\%) }\end{array}$ & Indicador 1 \\
\hline PT & 94,53 & 8,17 & $\mathbf{0 , 0 8 6 4}$ \\
\hline PFL & 90,7 & 8,6 & $\mathbf{0 , 0 9 4 8}$ \\
\hline PSDB & 88,52 & 10,99 & $\mathbf{0 , 1 2 4 2}$ \\
\hline PMDB & 77,58 & 11,49 & $\mathbf{0 , 1 4 8 1}$ \\
\hline PTB & 82,55 & 13,66 & $\mathbf{0 , 1 6 5 5}$ \\
\hline PPB & 74,04 & 12,76 & $\mathbf{0 , 1 7 2 3}$ \\
\hline PDT & 90,55 & 15,91 & $\mathbf{0 , 1 7 5 7}$ \\
\hline
\end{tabular}

Fonte: Elaboração Própria baseada no Banco de Dados Legislativo, CEBRAP.

A partir da Tabela 3, podemos, portanto, confirmar nossa hipótese sobre a dispersão da disciplina partidária do PDT na votação da reforma administrativa. Ou seja, podemos observar acima que, mesmo ponderando a dispersão da disciplina desse partido pela disciplina média (Indicador 1), a dispersão da disciplina ainda é a maior se comparada aos outros seis partidos da amostra.

Diferentemente do PDT, vemos que o PT, não apenas teve a maior taxa de disciplina dentre todos os sete partidos $(94,53 \%)$ durante as votações da reforma administrativa, mas também teve o menor desvio-padrão $(0,0864)$. 
Ainda dentro desse grupo de partidos disciplinados (disciplina média acima de 90\%), há um outro partido que mereceria atenção. Dos partidos selecionados e que fizeram parte da coalizão governista de centro-direita do governo FHC (PPB, PFL, PTB, PMDB e PSDB), o PFL é o que manteve a maior média de disciplina (90,7\%) durante as votações do PEC 173.

Além disso, esse partido apresentou o segundo menor grau de dispersão da disciplina nas 34 votações consideradas (Indicador $1=0,0948$ ), isto é, deteve uma alta (comparado aos outros cinco partidos da coalizão de FHC) estabilidade do grau de disciplina nestas votações. Portanto, mais à frente, faremos alguns comentários a respeito da elevada disciplina que a bancada do PFL teve durante as votações da reforma administrativa.

Por ora, continuando a classificação dos partidos de acordo com a disciplina, podemos construir mais dois grupos de acordo com o grau de fidelidade da bancada à indicação do líder do seu partido na votação da reforma administrativa.

Podemos colocar o PSDB (88,52\%) e o PTB (82,55\%), com médias em torno de $85 \%$ de votos disciplinados em um segundo grupo; e o PMDB $(77,58 \%)$ е о PPB (74,04\%) em um terceiro grupo em que a média de votos disciplinados se situa em torno de $75 \%$.

Quando calculamos a disciplina média dos sete partidos juntos, chegamos ao valor de, aproximadamente, 85,5\% durante as votações do PEC 173. No entanto, se calcularmos a média dos sete partidos juntos levando em conta as cadeiras que cada um deles deteve, em média, na Câmara dos Deputados - ou seja, se ponderarmos a disciplina pelo peso de cada partido na Câmara ${ }^{34}$ - a disciplina diminui um pouco

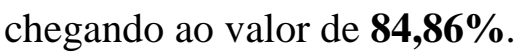

\footnotetext{
${ }^{34}$ Conforme "método" definido na parte anterior, utilizado para ponderar a média de disciplina partidária para os sete partidos conjuntamente.
} 
Com este mesmo "método" calculamos a disciplina média dos cinco partidos considerados aqui e que fizeram parte da coalizão de centro-direita de apoio ao presidente Fernando Henrique Cardoso (PPB, PFL, PTB, PMDB, PSDB), e chegamos

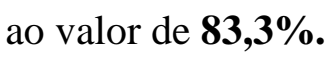

Nesse sentido, o governo FHC deteve, aproximadamente, 332 votos (83,3\% * 398) de sua coalizão ampliada durante a votação do PEC 173. Este número significa, portanto, que ao longo das votações, o governo do presidente FHC contou, em média, com um significativo excedente de parlamentares (332 - $308=24$ parlamentares) para aprovar o PEC 173 na Câmara dos Deputados.

Na verdade, o executivo ganhou 30 das 32 votações para as quais existiam dados sobre a indicação de voto de sua liderança. Portanto, o executivo obteve quase $\mathbf{9 4 \%}$ (93,75\%) de sucesso nas suas indicações. Perdeu apenas duas votações em que cabia a ele (governo) obter a maioria qualificada. ${ }^{35}$

A primeira votação em que o governo foi derrotado foi referente a um assunto que já vinha causando desacordos desde a tramitação na Comissão Especial, ou seja, a estabilidade - neste caso, a estabilidade dos futuros servidores públicos. O jornal $O$ Estado de S. Paulo (OESP) descreveu o fato:

“Ajudadas por rebeldes do PPB, PMDB, PFL e até PSDB, as oposições conseguiram retirar do texto do relatório do deputado Moreira Franco (PMDB-RJ) a figura do emprego público, um dispositivo que permitiria a contratação de funcionários sem estabilidade. Para manter o texto, o governo precisava de 308 votos e só obteve 298, 142 votaram contra e 8 se abstiveram”. (OESP, 24 de abril de 1997).

\footnotetext{
${ }^{35}$ Quanto às votações em que o governo foi derrotado, há dúvida em relação a uma votação. Ela se referia à aprovação da redação final do PEC 173 votada no $1^{\circ}$ turno em 12 de novembro de 1997 . Há uma incompatibilidade nos dados. O jornal OESP (13 de novembro de 1997) publicou uma matéria dizendo que o governo conseguira aprovação e que a votação requeria maioria simples. (No entanto, houve discussões da base governista com os parlamentares da oposição que diziam que a redação posta em votação não condizia com as matérias aprovadas na Câmara e, portanto, deveria exigir maioria qualificada para sua aprovação). Os dados do Banco de Dados Legislativos do Cebrap atribuíram quorum qualificado para a votação desta mesma matéria e, portanto, com os votos considerados no banco de dados ( $\operatorname{sim}=267$; não=143), a redação final não teria sido aprovada. No entanto, como a aprovação da redação do $1^{\circ}$ turno é necessária para que a votação seja levada ao segundo turno - e a votação seguinte foi justamente referente ao segundo turno - consideramos que o governo aprovou a redação e computamos no trabalho como votação ganha pelo governo.
} 
Nesta votação, de acordo com cálculos feitos a partir dos dados do "Banco Legislativo” do Cebrap, embora a disciplina partidária tenha ficado bem abaixo da média desses quatro partidos (PPB, PFL, PMDB e PSDB), esta disciplina baixa ficou bastante concentrada em dois dos quatro partidos citados, isto é, no PPB (60\%) e no PMDB (61\%).

Foram justamente esses partidos (que não fizeram parte da coalizão eleitoral que elegeu FHC) que mais contribuíram proporcionalmente para a derrota do governo nessa votação.

A outra votação perdida pelo governo foi relativa à fixação do subteto para os funcionários públicos dos estados e municípios. O governo, assim como na outra votação perdida, havia proposto voto favorável, mas não conseguiu alcançar os 308 votos necessários.

O jornal OESP (11 de junho de 1997) atribuiu, praticamente, toda a responsabilidade pela derrota ao $\mathrm{PMDB}$, devido ao fato dos ministros deste partido terem entrado em desacordo com o governo e o retaliarem, não garantindo os votos de suas respectivas bases ao governo.

No entanto, verificamos a disciplina partidária nos outros partidos da coalizão governista e observamos que eles também se comportaram com taxas de indisciplina em torno de $40 \%$.

Com exceção do PFL e do PSDB que tiveram taxas de disciplina partidária de 86\% e 77\%, respectivamente; o PPB e o PTB na votação do subteto tiveram taxas de disciplina menores que a do PMDB nesta votação: 60\%; 61\%; e 62\%, respectivamente. Portanto, o OESP (11/06/97) se equivocou em atribuir a “traição maior” ao PMDB. 
Nas demais votações, em que o líder do governo na Câmara dos Deputados indicou o voto, o executivo foi bem-sucedido. Houve apenas outras duas votações que devem ser destacadas pela dificuldade enfrentada pelo executivo.

Nestas duas votações, o executivo conseguiu a aprovação apenas com os 308 votos necessários. Uma foi referente à votação do substitutivo da comissão e a outra relacionada ao DVS n. 40, novamente relacionada à estabilidade dos servidores.

A estratégia do executivo em relação à votação do substitutivo da comissão ${ }^{36}$ foi realizar um acordo com os parlamentares garantindo que a reforma administrativa, que previa a fixação de tetos de remuneração aos funcionários públicos, não seria aplicada aos funcionários públicos que detivessem cargos eletivos. (Melo, 2002, p.163).

No entanto, pelo fato dessa medida ter tido uma repercussão negativa na opinião pública e nos setores organizados da sociedade, houve protesto de vários parlamentares, mesmo dentro da base governista. ${ }^{37}$ Esse fato levou a uma disciplina bem abaixo da média no PFL (77,5\%); no PPB (67,5\%) e no PMDB (63,3\%) e à disciplina partidária máxima nos partidos de oposição (PDT e PT), 100\%.

Mesmo assim, a barganha realizada pelo executivo com os parlamentares deu o resultado esperado, pois, apesar da repercussão negativa do acordo, 140 dos 308 parlamentares necessários para aprovação se encontravam na situação de acúmulo de aposentadorias e/ou cargos. E, portanto, seriam beneficiados com a fixação de um “extra-teto” para os cargos públicos eletivos. (Melo, 2002).

A outra votação em que o governo conseguiu apenas os 308 votos necessários foi novamente referente à estabilidade do servidor. A votação teve o maior quorum

\footnotetext{
${ }^{36}$ A votação do substitutivo da comissão foi a segunda votação referente ao PEC 173 na Câmara.

37 "Acordo é mesquinho", Folha de S. Paulo (FSP), 09/Abr/97; "Exceção ao teto é idéia sem 'pai"', FSP, 10/Abr/97; "Extrateto pode ser alterado no plenário”, FSP, 11/Abr/97; "Governo não confia na aprovação do acordo”, FSP, 11/Abr/97; “Senadores reagem contra o extrateto”, FSP, 12/Abr/97.
} 
dentre as 37 votações consideradas (495 parlamentares presentes) e um índice de abstenção baixo (5 abstenções).

O resultado em termos de votos que seguiram a indicação do líder do governo foi de 308 votos a favor do executivo e 182 contra. Portanto, esta foi a votação referente à reforma administrativa em que houve a maior divisão entre os parlamentares na Câmara.

A disciplina partidária dos partidos de oposição (PDT e PT) quanto à estabilidade foi de 100\%. Quanto aos partidos da coalizão ampliada, as taxas de disciplina ficaram com estes valores: PSDB (86,6\%); PFL (83,02\%); PTB (73,91\%); PPB (68,35\%); PMDB (57,45\%).

Ou seja, a bancada do PMDB quase se dividiu ao meio nesta votação, apresentando um índice de disciplina de, aproximadamente, 57\%. O PPB, o outro partido que não fazia parte da coalizão eleitoral, teve a segunda menor taxa de disciplina (68\%) nesta mesma votação.

Nesse sentido, podemos notar que, no caso da reforma administrativa, o governo obteve poucas derrotas durante as votações (2 de 37 votações) e, conseqüentemente, foi bem-sucedido na aprovação de suas medidas.

Encontrou problemas em alguns assuntos controversos, porém a considerável disciplina dos partidos de sua coalizão (83,3\% em média) permitiu um bom resultado para o executivo na votação da reforma administrativa. À luz da votação da reforma administrativa, poderíamos ainda fazer algumas qualificações a essa afirmação.

Poderíamos sugerir a hipótese de que o fato de um determinado partido participar ou não da coalizão eleitoral com o partido do Presidente pode influenciar no apoio e na disciplina das votações de proposições do executivo. 
De acordo com os dados anteriores, o PPB e o PMDB - que não participaram da coalizão eleitoral, mas que integraram a coalizão de governo (coalizão ampliada) e também conseguiram ministérios - não só tiveram as menores médias de disciplinas nas votações dentre todos os partidos, como também, tiveram as menores taxas de disciplina nas votações de matérias controversas da reforma administrativa.

Seria necessário testar essa proposição em outros governos; em outras votações e ainda com outros partidos, para controlar as especificidades internas do PPB e do PMDB. No entanto, acreditamos que com essa breve análise da votação de uma reforma específica poderíamos, ao menos, sugerir esta hipótese, a ser investigada em futuros trabalhos.

Outra observação importante a ser feita sobre o comportamento dos partidos políticos na votação da reforma administrativa é a respeito do PFL. Como vimos acima, esse partido foi o que deteve a segunda maior taxa de disciplina $(90,7 \%)$ nas votações da reforma administrativa (ou a maior taxa de disciplina se considerado apenas os partidos da base aliada do governo) e a segunda menor dispersão da taxa de disciplina (ou a menor taxa de dispersão se considerados apenas os partidos da base aliada do governo) ao longo das 37 votações (Indicador 1 = 0,0948).

O fato do PFL deter o segundo maior grau de fidelidade à indicação do seu líder poderia nos causar surpresa a priori - especialmente, quando levamos em conta o estudo de Rodrigues (2002) sobre a composição social dos partidos políticos brasileiros.

Segundo Rodrigues (2002, p. 37), o PFL seria o "partido mais burocrático das seis legendas examinadas”. O autor mostra que o partido teria em sua composição parlamentar 10,5\% de funcionários de altos cargos do governo federal somados a 11,4\% de funcionários de altos cargos de governos estaduais e 1,9\% provenientes do baixo e médio funcionalismo público. (Rodrigues, 2002, p. 38). 
Nesse sentido, caberia a indagação de qual o incentivo de um partido - que tem quase um quarto (23,8\%) de sua bancada proveniente da administração pública - para votar favoravelmente em um projeto que em princípio pretende alterar o status quo da administração pública - e que, portanto, afetaria inevitavelmente os interesses cristalizados em torno desta.

Essa aparente contradição é utilizada por Roma (2002) para justificar o seu argumento de que a aliança que o PSDB fez com o PFL seria mais por motivos programáticos/ideológicos do que por razões pragmáticas.

"Do ponto de vista analítico, é possível argumentar que sua [do PSDB] aliança com o PFL não representou, portanto, nenhuma ruptura com seu programa original, nem mesmo uma descaracterização de sua essência ideológica. Na verdade, é possível até mesmo perceber o contrário, ou seja, a mudança de posicionamento do PFL no governo Fernando Henrique em relação às funções do Estado, principalmente no apoio do partido às medidas de redução da máquina pública que transferia recursos do Estado necessários à sobrevivência de sua organização em certas localidades”. (Roma, 2002, p. 78, grifos nossos).

Se Roma (2002) estiver de fato se referindo ao PDRAE como uma dessas medidas que "visavam à redução da máquina pública” - o que, ao nosso ver, parece ser o caso -, seria importante fazer alguns comentários a respeito de seus argumentos.

Diferentemente de Roma (2002), entendemos que o apoio do PFL à reforma administrativa não se configuraria como razão suficiente para alegar mudança de posicionamento desse partido (que seria derivada do fato dessas reformas, supostamente, prejudicarem os interesses de grande parte de sua bancada - os funcionários públicos).

É possível argumentar que não há nada na proposta da reforma administrativa do governo FHC que explique uma possível mudança de posicionamento do PFL.

Ou seja, conforme descrito na introdução deste trabalho, podemos ver que seriam os funcionários públicos do baixo e do médio escalão, os principais prejudicados com a reforma administrativa. Enquanto isso, os funcionários dos altos postos da 
administração pública não arcariam com os custos da reforma - na verdade, eles teriam até os seus cargos “valorizados” após a implementação do PDRAE. (Cheibub, 2000, p. 131).

Ora, podemos ver que a grande maioria do grupo dos "burocratas" dentro do PFL advém justamente desses funcionários que seriam valorizados com a reforma $(22 \%)$.

Portanto, a aparente contradição do forte apoio do PFL à reforma administrativa não se sustenta quando observamos mais de perto quem seriam os reais prejudicados pela reforma administrativa, bem como, a composição desagregada da base parlamentar do PFL.

Nesse sentido, a alta fidelidade do PFL - partido com grande parte de seus parlamentares advindos do alto escalão do funcionalismo - às proposições do MARE sugere que o alto funcionalismo público poderia ter tido influência sobre a reforma administrativa.

Levando em conta o estudo de Cheibub (2000), não estamos afirmando que essa influência tenha se dado de maneira organizada, direta e explícita. Tampouco estamos alegando que o fato de uma grande parte da bancada do partido ser constituída por um determinado segmento da sociedade levaria o partido em questão a votar mecanicamente em favor dos interesses desse setor social.

Ao nosso ver, para fazer esta afirmação, seria necessário realizar pesquisas mais aprofundadas, para demonstrar claramente como se deu - i. e., "o mecanismo que levou a” (Elster, 1994, p. 24) - a eventual participação do alto funcionalismo nas votações da reforma administrativa por intermédio do PFL. 
Gostaríamos de argumentar, sim, que não há motivos para afirmar que o fato do PFL apoiar a reforma administrativa de FHC representa um ajuste (ou abandono) do programa/interesse deste partido.

Ou seja, não existe contradição e não deveria causar estranhamento o fato do PFL - um partido com um quarto da sua bancada formada por parlamentares provenientes do funcionalismo público - ter dado um elevado apoio à reforma administrativa do governo FHC.

Afirmação essa que, evidentemente, se diferencia da alegação de que o alto funcionalismo público federal se mobilizou e agiu ativamente na votação da reforma administrativa.

Feitas, portanto, as considerações sobre o papel dos partidos políticos na votação da reforma administrativa do governo FHC, passaremos então à análise dos argumentos tanto da literatura, que alega que os governadores estaduais têm uma influência sistemática nas votações no legislativo federal (Abrucio e Samuels, 1997 apud Abrucio e Costa, 1999, p. 14; p. 66), assim como, dos estudos, que defendem a relevância dos governadores no caso específico da aprovação da reforma administrativa do governo FHC (Bresser Pereira, no prelo e Melo, no prelo apud Schneider, 2001, p. 9; Melo, 1998, pp. 10-12 apud Abrucio e Costa, 1999, p. 68).

\section{A participação dos governadores estaduais na votação do PEC/173}

Conforme mostramos na parte referente às instituições políticas brasileiras, parte da literatura argumenta que os governadores estaduais teriam um papel importante na aprovação de matérias no legislativo federal.

Além disso, vimos também no Capítulo 1 que no caso específico da reforma administrativa, os estudos consideraram o apoio dado pelos governadores ao PDRAE 
fundamental tanto para sua viabilidade política (Gaetani, 2000; Gaetani e Heredia, 2002, p. 14; Melo, 2002, p. 172), como também, para sua aprovação no Congresso (Abrucio e Costa, 1999; Schneider, 2001, p. 9).

De acordo com esses estudos, não faltaram incentivos para os governadores apoiarem a reforma administrativa do governo FHC. Estes seriam referentes ao fato da reforma administrativa: (i) liberar recursos do orçamento comprometidos com o pagamento dos servidores públicos (Gaetani e Heredia, 2002, p. 14; Melo, 2002, p. 172); (ii) possibilitar o cumprimento da Lei Camata (Gaetani, 2000, p. 6; Abrucio e Costa, 1999, p. 159); (iii) abrir canais de renegociação das dívidas estaduais com a União (Abrucio e Costa, 1999, p. 67) e ainda; (iv) motivos relacionados à esfera eleitoral (aumento do poder de patronagem e emenda da reeleição).

Portanto, excluindo esse último incentivo de ordem eleitoral, os incentivos apontados estariam associados ao estado fiscal e financeiro dos governos estaduais. Nesse sentido, analisaremos, primeiramente, a relação entre o estado fiscal e financeiro dos Estados e o apoio ativo dos governadores ao PDRAE.

Além disso, verificaremos também qual foi a contribuição efetiva dos governadores estaduais para a aprovação da reforma administrativa do governo FHC na Câmara dos Deputados.

Para essa segunda tarefa, a opção foi - como descrito anteriormente - calcular o índice de unidade da bancada estadual de deputados federais nas votações da reforma administrativa do governo FHC. ${ }^{38}$

Antes, entretanto, de fazer essas duas análises (do apoio ativos dos governadores ao PDRAE e de sua influência nas votações da reforma administrativa), descreveremos abaixo os dados coletados para construir dos indicadores.

\footnotetext{
${ }^{38}$ Partimos do pressuposto de que para que os governadores estaduais tivessem uma influência importante nas votações, eles teriam que contar com uma bancada que votassem com um razoável grau de unidade.
} 
Dividimos os indicadores a serem utilizadas na análise em duas tabelas. $\mathrm{Na}$

Tabela 4, abaixo apresentamos a coesão média dos deputados federais por estado durante as votações da reforma administrativa e, além disso, indicamos também o tamanho de cada uma das bancadas estaduais e o peso que os partidos, participantes da coalizão ampliada de FHC (PPB, PFL, PTB, PMDB, PSDB) ${ }^{39}$, tinha (percentualmente) sobre a bancada estadual. ${ }^{40}$

Apresentamos ainda nessa mesma tabela, o desvio-padrão da coesão nas votações em cada um dos estados, pois, somente a apresentação da coesão média seria insuficiente para saber ao certo como foi a coesão da bancada nas 37 votações. ${ }^{41}$ E, por fim - da mesma forma que ponderamos a dispersão da disciplina partidária construindo o Indicador 1 na Tabela 3 -, com o desvio-padrão da coesão e a coesão média da bancada estadual, construímos o Indicador 2 que permite comparar a dispersão da coesão entre os estados. ${ }^{42}$

A partir dos dados da Tabela 4, calculamos a média da coesão da bancada estadual $(\mathbf{7 6 , 8 1 \% )}$ e a média do desvio-padrão da coesão nas 27 unidades federativas (0,1345). No entanto, com o mesmo “método" que aplicamos para determinar a

\footnotetext{
${ }^{39}$ Para construir essa última variável [Peso dos Partidos da "Coalizão Ampliada" de FHC na Bancada Estadual (\%)], consultamos o "Banco de dados legislativos" do Cebrap e dividimos a quantidade de deputados pertencentes a esses cinco partidos (PPB, PFL, PTB, PMDB, PSDB) sobre o total de deputados da bancada estadual em questão.

${ }^{40}$ Retiramos da Tabela 3 uma variável que continha o número de partidos representados na bancada estadual devido ao fato dessa variável apresentar uma alta correlação, estatisticamente significante, tanto com o "tamanho da bancada" $(0,802)$ como com a variável "peso dos partidos na coalizão ampliada do governo FHC” $(-0,502)$.

${ }^{41}$ É o caso do Acre, em que a média de coesão é maior que 80\%, porém o desvio-padrão é o segundo maior encontrado nos Estados do país. Portanto, fica a dúvida da representatividade desse valor (81,76\%), pois com um desvio-padrão tão elevado $(0,1682)$ a coesão se manteve relativamente pouco próxima aos $81,76 \%$ durante as votações.

${ }^{42}$ Da mesma forma que calculamos o Indicador 1 na análise da disciplina partidária, dividimos o valor do desvio-padrão pela coesão média em um determinado Estado e obtivemos o Indicador 2.
} 
disciplina partidária média na Câmara dos Deputados, ${ }^{43}$ calculamos a média ponderada da coesão para o país inteiro e chegamos a um valor um pouco mais baixo que o valor anterior, ou seja, chegamos ao valor de 73,96\% de coesão dos deputados em relação às bancadas estaduais. Além disso, calculamos também a média do Indicador 2 $(0,1767)$.

\footnotetext{
${ }^{43}$ Para ponderar os valores na coesão média nacional, multiplicamos a coesão média de um Estado com o valor da divisão da sua bancada pelos 513 deputados. Por exemplo, no caso de SP, o cálculo foi o seguinte: coesão média de SP $(67,94 \%) *$ [bancada de SP (70) / total de deputados na câmara (513)] = 9,27. Calculamos os valores para cada um dos Estados e, posteriormente, somamos todos os 27 valores obtendo então a coesão estadual média no país. Assim como nos cálculos da fidelidade partidária, esse procedimento nos pareceu mais adequado na medida em que - conforme veremos abaixo - o tamanho da bancada está negativamente associado com a coesão do Estado. Ou seja, se simplesmente agregássemos a coesão de um Estado cuja bancada tem oito deputados com uma bancada do tamanho da do Estado de São Paulo (que têm 70 deputados) a coesão estadual média no país ficaria superestimada.
} 


\section{Tabela 4}

\begin{tabular}{|c|c|c|c|c|c|c|}
\hline UF & Região & $\begin{array}{c}\text { Tamanho } \\
\text { da } \\
\text { Bancada }\end{array}$ & $\begin{array}{c}\text { Peso dos } \\
\text { Partidos da } \\
\text { Coalizão } \\
\text { Ampliada } \\
\text { de FHC na } \\
\text { Bancada } \\
\text { Estadual } \\
(\%) \\
\end{array}$ & $\begin{array}{l}\text { Coesão } \\
\text { Média (\%) }\end{array}$ & $\begin{array}{l}\text { Desvio- } \\
\text { Padrão da } \\
\text { Coesão } \\
(\%)\end{array}$ & $\begin{array}{c}\text { Indicador } 2 \\
\text { (Desvio- } \\
\text { Padrão / } \\
\text { Coesão } \\
\text { Média) }\end{array}$ \\
\hline $\mathrm{RS}$ & Sul & 31 & 61,4 & 62,93 & 14,11 & 0,2242 \\
\hline PA & Norte & 17 & 76,5 & 66,92 & 11,97 & 0,1789 \\
\hline $\mathrm{SP}$ & Sudeste & 70 & 71 & 67,94 & 11,62 & 0,1710 \\
\hline $\mathrm{SC}$ & Sul & 16 & 75,1 & 68,27 & 11,72 & 0,1717 \\
\hline $\mathrm{PE}$ & Nordeste & 25 & 60 & 68,76 & 15,8 & 0,2298 \\
\hline $\mathrm{RJ}$ & Sudeste & 46 & 68,1 & 69,30 & 12,97 & 0,1872 \\
\hline ES & Sudeste & 10 & 72,8 & 69,73 & 15,36 & 0,2203 \\
\hline DF & $\begin{array}{c}\text { Centro- } \\
\text { Oeste }\end{array}$ & 8 & 50 & 70,27 & 14,83 & 0,2110 \\
\hline SE & Nordeste & 8 & 62,6 & 73,99 & 15,7 & 0,2122 \\
\hline $\mathrm{AP}$ & Norte & 8 & 75 & 75 & 16,67 & 0,2223 \\
\hline$M G$ & Sudeste & 53 & 84,6 & 75,32 & 11,65 & 0,1547 \\
\hline PR & Sul & 30 & 84,3 & 76,04 & 9,62 & 0,1265 \\
\hline$B A$ & Nordeste & 39 & 75,6 & 77,14 & 8,51 & 0,1103 \\
\hline CE & Nordeste & 22 & 88,4 & 77,15 & 12,48 & 0,1618 \\
\hline $\mathrm{AL}$ & Nordeste & 9 & 96,8 & 77,19 & 17,35 & 0,2248 \\
\hline PB & Nordeste & 12 & 97,8 & 78,38 & 15,16 & 0,1934 \\
\hline $\mathrm{MA}$ & Nordeste & 18 & 76,5 & 78,53 & 12,63 & 0,1608 \\
\hline GO & $\begin{array}{c}\text { Centro- } \\
\text { Oeste }\end{array}$ & 17 & 76,4 & 79,13 & 12,15 & 0,1535 \\
\hline AM & Norte & 8 & 97,2 & 79,73 & 12,96 & 0,1625 \\
\hline $\mathrm{RO}$ & Norte & 8 & 81,3 & 80,74 & 13,69 & 0,1696 \\
\hline$A C$ & Norte & 8 & 100 & 81,76 & 16,82 & 0,2057 \\
\hline MT & $\begin{array}{l}\text { Centro- } \\
\text { Oeste }\end{array}$ & 8 & 73,8 & 82,09 & 11,98 & 0,1459 \\
\hline MS & $\begin{array}{l}\text { Centro- } \\
\text { Oeste }\end{array}$ & 8 & 100 & 84,46 & 14,85 & 0,1758 \\
\hline $\mathrm{TO}$ & Norte & 8 & 100 & 86,15 & 13,43 & 0,1559 \\
\hline $\mathrm{RN}$ & Nordeste & 8 & 100 & 87,84 & 15,16 & 0,1726 \\
\hline $\mathrm{RR}$ & Norte & 8 & 96,6 & 89,19 & 13,55 & 0,1519 \\
\hline $\mathrm{PI}$ & Nordeste & 10 & 100 & 90 & 10,54 & 0,1171 \\
\hline Brasil & - & 513 & 81,55 & $\begin{array}{c}73,96 \\
\text { (média } \\
\text { ponderada) }\end{array}$ & 13,45 & 0,1767 \\
\hline
\end{tabular}

Fonte: Elaboração própria a partir dos dados do "Banco de Dados Legislativos" do Cebrap. 
A partir dessa tabela, vemos, portanto, que o grau de coesão estadual nas votações da reforma administrativa variou nas unidades federativas entre, aproximadamente, 63\% e 90\%.

Podemos observar ainda que - tal como fizemos na análise da disciplina partidária - seria possível dividir as 27 unidades federativas em três grupos principais, de acordo com o grau de coesão.

Em um primeiro grupo, colocamos as unidades federativas cuja coesão ficou entre 61\% e 70\%. Nesse grupo, estariam inseridos dois dos três estados da Região Sul (Rio Grande do Sul e Santa Catarina); três dos quatro estados da Região Sudeste (São Paulo, Rio de Janeiro e Espírito Santo), o Distrito Federal da região Centro-Oeste e Pernambuco e Pará, da região nordeste e norte, respectivamente; totalizando assim oito unidades federativas.

Agrupamos em um segundo conjunto, as unidades federativas cujas médias da coesão se situaram no intervalo de $71 \%$ a $80 \%$. Esse grupo é composto por doze estados, metade dos quais pertencentes à Região Nordeste (Sergipe, Bahia, Ceará, Alagoas, Paraíba, Maranhão). Além dos estados do nordeste, ficariam nesse grupo também: os estados que completam a região sudeste e sul (Minas Gerais e Paraná, respectivamente) e Amapá, Amazonas, Rondônia da região norte e Goiás da região centro-oeste. Portanto, seria esse, o grupo com maior número de unidades federativas (células com preenchimento cinza).

Finalmente, em um terceiro grupo, colocaríamos os sete estados cuja coesão média ficou entre $81 \%$ e $90 \%$. Esse grupo seria composto por três dos sete estados da Região Norte (Acre, Tocantins e Roraima), dois estados da região nordeste (Rio Grande do Norte e Piauí) e pela metade dos estados da Região Centro-Oeste (Mato Grosso e Mato Grosso do Sul). 
Para facilitar a exposição e descrição tanto da coesão estadual média como da dispersão dessa coesão (Indicador 2), testaremos a possibilidade de agregar os estados de acordo com as macro-regiões do país às quais pertencem.

Esse recurso não apenas facilitará a obtenção de um panorama geral dos dados ${ }^{44}$, mas também nos parece possível, na medida em que, quando separamos os estados de acordo com o grau de coesão de suas bancadas, foi possível encontrar uma certa proximidade entre os estados de uma mesma região.

Segue abaixo então o Quadro 1, com a comparação das médias das coesões estaduais entre as cinco macro-regiões do Brasil e, posteriormente, algumas considerações sobre a validade que o procedimento de agregar os estados de acordo com regiões teve para a análise. ${ }^{45}$

\section{Quadro 1}

Média da Coesão da Bancada Estadual, por região do paß̂s

Coesão Média da Bancada Estadual (\%)
\begin{tabular}{|l|l|r|r|}
\hline REGIÃO & Mean & N & Std. Deviation \\
\hline Sul & 69,0800 & 3 & 6,59243 \\
Sudeste & 70,5725 & 4 & 3,25566 \\
Nordeste & 78,7756 & 9 & 6,51358 \\
Centro-Oeste & 78,9875 & 4 & 6,20722 \\
Norte & 79,9271 & 7 & 7,32628 \\
\hline
\end{tabular}

a. Elaboração Própria com base nos dados do Banco de Dados Legislativo, CEBRAP.

\footnotetext{
${ }^{44}$ É inegável que agregar cada um dos vinte e sete valores da coesão e da dispersão (Indicador 2) em apenas cinco, facilitaria sobremaneira a descrição dos dados da Tabela 4.

${ }^{45}$ Agregar os Estados de acordo com as regiões as quais pertencem somente faz sentido se os valores estaduais a serem agregados são homogêneos ou próximos. Ou seja, não faria sentido, por exemplo, agregar os valores da coesão de dois Estados, que pertencem à mesma região, mas, entretanto, são muito distantes. Nesse caso, a média regional teria muito pouco a oferecer em termos explicativos das realidades desses dois Estados. Vamos, portanto, avaliar em quais regiões faz, relativamente, mais sentido agregar a coesão dos Estados através do desvio-padrão da média de coesão regional. Faremos isso também para os valores do Indicador 2 - i. e., vamos analisar o desvio-padrão da média regional do Indicador 2 para verificar em quais regiões faz mais sentido agregar os valores estaduais em termos regionais.
} 
A partir do Quadro 1, podemos perceber que os estados das Regiões Sul e Sudeste foram os que apresentaram, em média, a menor coesão da bancada estadual durante a votação da reforma administrativa do governo FHC (69,08\% e 70,57\%, respectivamente). Em seguida, com valores de coesão, aproximadamente, de 78\%, ficaram os estados da Região Nordeste (78,78\%) e Centro-Oeste (78,99\%). E, por fim, é possível ver que a Região Norte foi a região cujos estados tiveram o maior grau de coesão média durante a votação da reforma administrativa (79,93\%).

No entanto, resta saber se essas médias de coesão regionais são “representativas” das bancadas estaduais que compõem a região. Dividimos então o desvio-padrão do Quadro 1 pela média da coesão regional para comparar onde o procedimento de agregar a coesão estadual por regiões faria mais sentido e em quais delas faria menos sentido. Ou seja, pretendemos observar onde a média regional da coesão é mais representativa dos estados que a compõem.

Nesse sentido, chegamos ao resultado de que agregar a coesão dos estados, de acordo com a região ao qual pertencem, faria mais sentido para a Região sudeste (desvio-padrão/coesão regional $=0,0462){ }^{46}$ posteriormente para as regiões centro-oeste $(0,0786)$ e nordeste $(0,0826)$; e, por fim, faria menos sentido para as Regiões Norte $(0,0917)$ e Sul $(0,0954)$.

Em outras palavras, a partir dos dados do Quadro 1, pudemos perceber que a coesão das bancadas dos estados da Região Sudeste são as mais “homogêneas” - i. e., ES, MG, RJ e SP têm valores da coesão de suas bancadas estaduais mais “semelhantes” em comparação com as outras regiões - e a coesão das bancadas dos estados da Região Norte e Sul são as mais “heterogêneas”.

\footnotetext{
${ }^{46}$ Conforme vimos acima, isso seria mesmo de se esperar, uma vez que três dos quatro Estados (SP, RJ, ES) dessa região estariam incluídos em um mesmo grupo (coesão entre 61\% e 70\%) e o outro Estado (MG) pertenceria ao grupo imediatamente subseqüente (coesão entre $71 \%$ e $80 \%$ ). Portanto, a média regional de coesão encontrada $(70,57 \%)$ seria a mais “representativa” dentre as cinco regiões.
} 
Nesse contexto, estendemos este mesmo procedimento - i. e., agregar os estados de acordo com as macro-regiões às quais pertencem - para descrever a dispersão do grau de coesão em cada uma das bancadas estaduais durante as trinta e sete votações da reforma administrativa (agregar regionalmente os valores do Indicador

\section{2 da Tabela 4).}

\section{Quadro 2}

Média Regional do Indicador 2

\begin{tabular}{|c|c|c|c|}
\hline REGIÃO & $\begin{array}{l}\text { Média do } \\
\text { Indicador } 2\end{array}$ & $\mathrm{~N}$ & Std. Deviation \\
\hline Centro-Oeste & ,171587 & 4 & ,0292013 \\
\hline Sul & 174134 & 3 & ,0488990 \\
\hline Nordeste & ,175864 & 9 & ,0434607 \\
\hline Norte & 178111 & 7 & ,0264818 \\
\hline Sudeste & ,183286 & 4 & ,0280013 \\
\hline
\end{tabular}

a. Fonte: Elaboração Própria com base nos dados do Banco de Dados Legislativos, CEBRAP.

A partir do Quadro 2, podemos observar que é na Região Sudeste que a coesão dentro das bancadas estaduais variou mais durante as votações da reforma administrativa $(0,1833)$. Ou seja, de acordo com os nossos cálculos, a coesão das bancadas estaduais dessa região foi a que, em média, se manteve menos tempo em torno da média de coesão estadual - i. e., variou mais, em média, ao longo das trinta e sete votações da reforma administrativa.

Inversamente, vemos que foram as quatro bancadas estaduais da Região CentroOeste que votaram, em média, com maior estabilidade de coesão durante as votações da reforma administrativa $(0,1716)$. Ou seja, a coesão de cada uma das bancadas do DF, GO, MT e MS foi a que, em média, menos variou ao longo das votações. Entre esta 
Região e a Região Sudeste ficaram os estados das Regiões Sul (0,1741); Nordeste $(0,1759)$ e Norte $(0,1781)$.

Além disso, o desvio-padrão e a média regional do Indicador 2 (ambos presentes no Quadro 2) nos mostram que o procedimento de agregar os valores estaduais do Indicador 2 por região faz mais sentido para a Região Norte (desviopadrão/média regional do Indicador 2 = 0,1488) seguida das Regiões Sudeste $(0,1528)$, Centro-Oeste $(0,1702)$ e; menos sentido, para as Regiões Nordeste e Sul $(0,2473$ e 0,2808 , respectivamente).

Isto é, o Indicador 2 seria mais homogêneo entre os estados da Região Norte e mais discrepante entre os estados da Região Sul. Portanto, agregar regionalmente a dispersão da coesão das bancadas estaduais (Indicador 2) faria mais sentido se utilizado para os estados da Região Norte do que para os da Região Sul.

Em resumo, analisando conjuntamente os resultados encontrados nos Quadros 1 e 2, em termos de coesão das bancadas estaduais, seria mais adequado agregar os estados, em ordem decrescente, nas Regiões Sudeste, Centro-Oeste e Nordeste e, em menor grau, Norte e Sul.

Já em termos de dispersão da coesão da bancada estadual ao longo das votações da reforma administrativa seria mais adequado agregar os estados, em ordem decrescente, nas Regiões Norte, Sudeste e Centro-Oeste e, por fim, Nordeste e, novamente por último, Sul.

Deixamos de lado a descrição das características mais gerais das bancadas estaduais e apresentaremos na próxima tabela cinco variáveis construídas para indicar (i) o estado das finanças das unidades federativas do país; (ii) o quanto os governadores estavam interessados em ajustar as suas contas públicas e, por fim, (iii) o apoio ativo dado pelos governadores à reforma administrativa de FHC. 
A partir dos dados coletados em diversas fontes [Secretaria do Tesouro Nacional

(STN); Abrucio e Costa (1999); Rocha e Giuberti (2004); Melo (2002); Mora (2002);

Jornal Folha de São Paulo (FSP)] indicamos na Tabela 5:

1. A razão entre a dívida estadual e a receita corrente líquida em cada um das Unidades Federativas em 1996 (Mora, 2002, p. 21) para indicar o endividamento dos estados. ${ }^{47}$ (dívida/RCL)

2. Qual era o percentual médio da receita corrente líquida gastos com o pagamento de pessoal em cada um dos estados entre os anos de 1995 (ano de proposição do PDRAE) e 1997 (ano de votação da reforma administrativa) [Média da Razão Despesa Total com Pessoal / Receita Corrente Líquida_1995 a 1997 (\%)]. ${ }^{48}$ (Rocha e Giuberti, 2004, p. 37).

3. Com os dados do item acima, construímos uma variável dicotômica para indicar quais eram as unidades federativas que estavam, em média, cumprindo a Lei Camata - i. e., que estavam gastando menos de $60 \%$ da RCL com o pagamento de pessoal - entre o ano de proposição do PDRAE (1995) e o ano da votação da reforma administrativa (1997).

4. Além disso, apontamos a quantidade de programas ou iniciativas dos governos estaduais em direção ao corte de despesas com pessoal e/ou reformas nas suas administrações públicas para aumentar a eficiência (Quantidade de Programas Estaduais de Reforma Administrativa) ${ }^{49}$. (Abrucio e Costa, 1999, p. 167).

\footnotetext{
${ }^{47}$ Conseguimos os dados do endividamento apenas para o ano de 1996.

${ }^{48}$ Vamos adotar como variável explicativa a média entre esses três anos - e não apenas um dos anos em separado -, pois, em primeiro lugar, se adotássemos apenas um dos anos poderia ocorrer um viés na análise. O número de Estados, que estavam cumprindo a Lei Camata, passa de 3 em 1995 (RR, AM, TO) para 8 em 1996 (os estados que estavam cumprindo em 1995 mais CE, PB, BA, MG, SC) e 14 em 1997 (os Estados que estavam cumprindo em 1996 mais SP, AP, MA, MS, SE, MT). A partir desses dados, portanto, se optássemos pela adoção do ano de 1995 - quando apenas 3 das 27 unidades federativas vinham cumprindo a Lei Camata - haveria pouca contribuição dessa variável para a análise, pois nesse ano há pouca distinção entre os Estados - a "variável” em questão seria mais uma constante do que propriamente uma variável. Por outro lado, se adotássemos o outro extremo (ano de 1997 em que mais da metade dos Estados estavam cumprindo a Lei - 14 Estados), a análise também ficaria prejudicada, visto que a situação nesse ano guarda pouca relação com a situação dos Estados nos anos imediatamente anteriores. Além desse fato, justificamos a adoção da média dos três anos - e não apenas um deles -, pois, como veremos mais à frente, pretendemos relacionar essa variável com as demais (apoio ativo do governador ao PDRAE e Quantidade de programas estaduais de reforma administrativa), as quais não conhecemos exatamente os anos de referência. Nesse sentido, a análise poderia ficar prejudicada se, p. ex., pretendêssemos argumentar que os governadores estaduais declararam apoio ao PDRAE (ou mesmo propuseram os programas estaduais de reforma administrativa) devido ao fato de não estarem cumprindo a Lei Camata.

49 Para construir essa variável (Quantidade de Programas Estaduais de Reforma Administrativa), coletamos informações em Melo (2002) e FSP, mas, principalmente, em Abrucio e Costa (1999, p. 167). Esses últimos autores descrevem as medidas tomadas por alguns governos estaduais para reduzir os
} 
5. E, por fim, a preferência revelada por alguns governadores estaduais em ver a reforma administrativa federal aprovada (Apoio Ativo do Governador ao PDRAE). ${ }^{50}$

gastos com pessoal no período de 1995 a 1997. As medidas são: Programas de Demissão Voluntária (PDV); extinção/redução de cargos comissionados; reestruturação/venda das estatais; controle/corte de gratificações/vantagens; monitoramento da folha de pagamentos; definição/regulamentação de teto remuneratório, entre outras medidas, que totalizam dezesseis tipos.

${ }^{50}$ Para construir essa última variável a fim de verificar quais foram os governadores, que apoiaram ativamente a reforma administrativa de FHC (Apoio Ativo do Governador ao PDRAE), utilizamos o livro de Melo (2002) e o texto de Abrucio e Costa (1999), além de coletar informações no jornal Folha de São Paulo (FSP). Embora possamos concordar com futuras críticas de que essas fontes não seriam suficientes para determinar o valor dessa variável - e, portanto, que seria necessário pesquisas mais detalhadas da opinião dos governadores de cada um dos vinte e sete Estados brasileiros -, entendemos que tanto o livro de Melo (2002) e o texto de Abrucio e Costa (1999), assim como, o jornal A Folha de S. Paulo seriam referências, pelo menos, próximas (proxy) de quão engajado estavam os governadores estaduais no apoio à iniciativa federal. Sobretudo, porque em princípio a mídia tende a relatar os governadores, que mais se mostraram favoráveis ao PDRAE do governo federal. 


\section{Tabela 5}

\begin{tabular}{|c|c|c|c|c|c|}
\hline UF & $\begin{array}{l}\text { Relação } \\
\text { entre a } \\
\text { dívida } \\
\text { estadual e } \\
\text { a receita } \\
\text { corrente } \\
\text { líquida } \\
\text { (1996) } \\
\end{array}$ & $\begin{array}{c}\text { Média da } \\
\text { Razão Despesa } \\
\text { Total com } \\
\text { Pessoal/Receita } \\
\text { Corrente } \\
\text { Líquida_1995 a } \\
1997 \text { (\%) }\end{array}$ & $\begin{array}{l}\text { Cumprimento } \\
\text { da Lei } \\
\text { Camata } \\
\text { (1995-1997) }\end{array}$ & $\begin{array}{c}\text { Quantidade } \\
\text { de Programas } \\
\text { Estaduais de } \\
\text { Reforma } \\
\text { Administrativa }\end{array}$ & $\begin{array}{c}\text { Apoio Ativo } \\
\text { do } \\
\text { Governador } \\
\text { ao PDRAE }\end{array}$ \\
\hline$A C$ & 1,62 & 71,67 & não & 0 & não \\
\hline $\mathrm{AL}$ & 1,56 & 80,60 & não & 5 & não \\
\hline AM & 0,76 & 44,63 & sim & 3 & $\operatorname{sim}$ \\
\hline $\mathrm{AP}$ & 0,35 & 67,73 & não & 0 & não \\
\hline BA & 1,56 & 57,93 & sim & 11 & $\operatorname{sim}$ \\
\hline $\mathrm{CE}$ & 1,14 & 51,63 & sim & 6 & $\operatorname{sim}$ \\
\hline $\mathrm{DF}$ & 0,22 & 79,07 & não & 2 & $\operatorname{sim}$ \\
\hline$E S$ & 1,07 & 70,77 & não & 4 & $\operatorname{sim}$ \\
\hline GO & 3,64 & 72,13 & não & 1 & $\operatorname{sim}$ \\
\hline MA & 1,82 & 63,80 & não & 2 & não \\
\hline$M G$ & 2,18 & 68,70 & não & 1 & $\operatorname{sim}$ \\
\hline MS & 3,04 & 68,07 & não & 0 & não \\
\hline MT & 2,74 & 71,10 & não & 1 & $\operatorname{sim}$ \\
\hline $\mathrm{PA}$ & 0,76 & 67,13 & não & 2 & não \\
\hline PB & 1,33 & 58,17 & $\operatorname{sim}$ & 1 & $\operatorname{sim}$ \\
\hline $\mathrm{PE}$ & 1,41 & 79,67 & não & 0 & não \\
\hline $\mathrm{PI}$ & 2,11 & 78,53 & não & 2 & não \\
\hline PR & 0,99 & 69,03 & กล̃o & 3 & $\operatorname{sim}$ \\
\hline RJ & 1,81 & 110,27 & não & 1 & sim \\
\hline $\mathrm{RN}$ & 1 & 78,50 & não & 9 & não \\
\hline $\mathrm{RO}$ & 2,77 & 82,00 & não & 0 & não \\
\hline $\mathrm{RR}$ & 0,19 & 19,13 & sim & 0 & não \\
\hline $\mathrm{RS}$ & 2,04 & 80,57 & não & 3 & $\operatorname{sim}$ \\
\hline SC & 1,23 & 66,97 & não & 1 & não \\
\hline SE & 1,33 & 69,47 & não & 0 & $\operatorname{sim}$ \\
\hline $\mathrm{SP}$ & 2,63 & 57,87 & sim & 13 & sim \\
\hline TO & 1,04 & 45,03 & $\operatorname{sim}$ & 0 & não \\
\hline Brasil & 1,57 & 67,78 & - & 2,63 & - \\
\hline
\end{tabular}

Fonte: Elaboração própria a partir dos dados da Secretaria do Tesouro Nacional (STN); Abrucio e Costa (1999); Melo (2002); Mora (2002); Rocha e Giuberti (2004) e FSP. 
A finalidade da construção das cinco variáveis da Tabela 5 é, em primeiro lugar, analisar as motivações dos governadores para apoiar o PDARE - em especial, verificar se, como alega a literatura, é possível deduzir o apoio ativo dos governadores à reforma administrativa federal do estado fiscal e financeiro dos estados. Em seguida, com algumas das variáveis dessa tabela, analisamos a contribuição efetiva dos governadores estaduais para a aprovação da reforma na Câmara dos Deputados.

Portanto, na próxima seção, relacionamos a variável apoio ativo dos governadores ao PDRAE, especialmente, com as variáveis que indicam o estado fiscal e financeiro dos governos estaduais [Relação entre a dívida estadual e a receita corrente líquida (1996); Média da Razão Despesa Total com Pessoal/Receita Corrente Líquida_1995 a 1997 (\%); Cumprimento da Lei Camata (1995-1997)] para, finalmente, analisar a contribuição dos governadores estaduais para a aprovação do PEC 173.

Análise do apoio ativo dos governadores ao PDRAE

Antes de começar a apresentação das relações, é necessário descrever a variável dependente utilizada na análise abaixo. A partir do Quadro 3 abaixo, podemos perceber que a quantidade de governadores estaduais, que apoiou ativamente a reforma administrativa do governo FHC (14), é, aproximadamente, igual ao número de governadores que não apoiou (13). 


\section{Quadro 3}

Apoio do Governador ao PDRAE

\begin{tabular}{|ll|r|r|}
\hline & & Frequência & Percentual \\
\hline Valid & Não & 13 & 48,1 \\
& Sim & 14 & 51,9 \\
& Total & 27 & 100,0 \\
\hline
\end{tabular}

Feita essa consideração inicial, nos Quadros abaixo, pretendemos apresentar se algumas das variáveis da Tabela 5 se relacionam (ou, no limite, explicam) esse apoio ativo dos governadores ao PDRAE.

No Capítulo 1, vimos que, de acordo com alguns autores (Abrucio e Costa, 1999; Gaetani, 2000), um dos motivos pelos quais os governadores se interessaram pela reforma administrativa do governo FHC e passaram a apoiá-la seria devido ao fato desses estados estarem com as suas receitas fortemente comprometidas com o pagamento de pessoal e, portanto, poderem vir a ser punidos a partir da promulgação da Lei Camata em 1995.

Além disso, outros estudos (Melo, 2002; Gaetani e Heredia, 2002) afirmam também que pelo fato dos gastos com pagamento de pessoal estarem acima dos limites impostos pela Lei Camata, a reforma administrativa federal interessaria aos governadores desses estados, na medida em que possibilitaria a liberação desses recursos do orçamento para serem gastos em outras funções.

Por fim, Abrucio e Costa (1999) argumentam que os estados endividados e que queriam renegociar as suas dívidas com a União trocaram o apoio ao PDRAE com a abertura dos canais de renegociação das suas dívidas.

Portanto, a partir do que foi afirmado pela literatura, poderíamos esperar que o apoio ativo dos governadores ao PDRAE viesse dos governadores cujos estados (i) estivessem gastando, em média, mais em pagamento de pessoal - ou não estivessem 
cumprindo a Lei Camata - e também (ii) apresentassem um elevado nível de endividamento.

Comparamos então a média de gasto com pessoal e a média de endividamento do grupo de estados cujo governador apoiou ativamente o PDRAE, em relação ao grupo de governadores que não apoiou ativamente o plano do MARE. ${ }^{51}$

\section{Quadro 4}

\begin{tabular}{|c|c|c|c|}
\hline $\begin{array}{l}\text { Apoio do Governador } \\
\text { ao PDRAE }\end{array}$ & & $\begin{array}{l}\text { Relação entre } \\
\text { a dívida } \\
\text { estadual e a } \\
\text { receita } \\
\text { corrente } \\
\text { líquida (1996) }\end{array}$ & $\begin{array}{c}\text { Média da } \\
\text { Razão } \\
\text { Despesa Total } \\
\text { com } \\
\text { Pessoal/Receit } \\
\text { a Corrente } \\
\text { Líquida_1995 } \\
\text { a } 1997(\%) \\
\end{array}$ \\
\hline \multirow[t]{3}{*}{ Não } & Média & 1,45 & 66,83 \\
\hline & $\mathrm{N}$ & 13 & 13 \\
\hline & Desvio-padrão & ,8455 & 17,42 \\
\hline \multirow[t]{3}{*}{ Sim } & Média & 1,67 & 68,67 \\
\hline & $\mathrm{N}$ & 14 & 14 \\
\hline & Desvio-padrão & ,9047 & 15,72 \\
\hline \multirow[t]{3}{*}{ Total } & Média & 1,57 & 67,78 \\
\hline & $\mathrm{N}$ & 27 & 27 \\
\hline & Desvio-padrão & ,8671 & 16,27 \\
\hline
\end{tabular}

Podemos ver a partir do Quadro 4 que os governadores que apoiaram ativamente o PDRAE governavam Estados cuja relação entre dívida estadual e RCL $(1,67)$ e razão entre despesa com pessoal e RCL $(68,67 \%)$ era, em média, maior que a do grupo de governadores que não apoiou a reforma administrativa do governo FHC (1,45 e $66,83 \%$, respectivamente).

Entretanto, é possível observar que em ambos os grupos de governadores (a) a dívida estadual era, em média, maior que a receita corrente líquida do estado

\footnotetext{
${ }^{51}$ Nenhuma correlação entre essas três variáveis foi estatisticamente significante, assumindo um erro de $5 \%$.
} 
(dívida/RCL > 1) e, além disso, (b) que ambos os grupos - tanto dos governadores, que apoiaram, como dos governadores, que não apoiaram o PDRAE - estavam, em média, descumprindo a Lei Camata (gasto com pessoal > 60\% RCL).

Ou seja, a diferença entre o grupo de governadores que apoiou e que não apoiou ativamente o PDRAE é meramente quantitativa e mesmo, quantitativamente, pouco relevante. Pois, vemos que (i) ambos os grupos de governadores estavam com elevado nível de endividamento e descumprindo a Lei Camata e (ii) a diferença tanto em termos de gasto com pessoal como em termos de endividamento entre os dois grupos é relativamente pequena.

Para testar melhor a proposição, tentamos refinar a análise e criamos uma variável dicotômica (Dívida estadual maior que a receita líquida corrente) para diferenciar os estados, que tinham uma dívida menor ou igual do que a sua RCL (dívida $<$ ou = RCL), dos estados, que tinham um endividamento maior que a sua RCL em 1996 (dívida > RCL). ${ }^{52}$ E, posteriormente, utilizando a variável dicotômica Cumprimento da Lei Camata da Tabela 5, pretendemos identificar se o apoio ativo veio de fato dos governadores que poderiam ter problemas por não estarem cumprindo a Lei Camata. ${ }^{53}$

\footnotetext{
${ }^{52}$ A quantidade de Estados que tinham a dívida menor ou igual à RCL é sete. Portanto, são 20 os Estados que tinham a dívida maior que a RCL em 1996.

${ }^{53}$ É necessário ressaltar aqui que a correlação entre as variáveis dicotômicas Cumprimento da Lei Camata_1995 a 1997 e Dívida estadual maior que a receita líquida corrente (1996) não é estatisticamente significante. Mesmo tomando a variável Cumprimento da Lei Camata apenas para o ano de 1996 - ano de referência da variável Dívida estadual maior que a receita líquida corrente - a correlação entre essas duas variáveis também não seria estatisticamente significante.
} 


\section{Quadro 5}

Dívida estadual maior que receita corrente líquida (1996) * Apoio do Governador ao PDRAE Crosstabulation

\begin{tabular}{|c|c|c|c|c|}
\hline & & \multicolumn{2}{|c|}{$\begin{array}{c}\text { Apoio do Governador } \\
\text { ao PDRAE }\end{array}$} & \multirow[b]{2}{*}{ Total } \\
\hline & & Não & Sim & \\
\hline \multirow[t]{2}{*}{$\begin{array}{l}\text { Dívida estadual maior } \\
\text { que receita corrente } \\
\text { líquida (1996) }\end{array}$} & $\begin{array}{l}\text { Quantidade de UF } \\
\text { \% dentro do grupo } \\
\text { Dívida estadual maior } \\
\text { que receita corrente } \\
\text { líquida (1996) }\end{array}$ & $57,1 \%$ & $42,9 \%$ & $100,0 \%$ \\
\hline & $\begin{array}{l}\text { Quantidade de UF } \\
\text { \% dentro do grupo } \\
\text { Dívida estadual maior } \\
\text { que receita corrente } \\
\text { líquida (1996) }\end{array}$ & $45,0 \%$ & $55,0 \%$ & $100,0 \%$ \\
\hline Total & $\begin{array}{l}\text { Quantidade de UF } \\
\text { \% dentro do grupo } \\
\text { Dívida estadual maior } \\
\text { que receita corrente } \\
\text { líquida (1996) }\end{array}$ & 13 & 14 & $100,0 \%$ \\
\hline
\end{tabular}

Observamos no Quadro 5 acima que a relação entre endividamento dos estados e apoio ativo dos governadores ao PDRAE de fato não é tão direta e evidente. Ou seja, separando os grupos de acordo com a relação da dívida/RCL, vemos, em primeiro lugar, que a maior parte do grupo de governadores, cujos estados tinham uma dívida menor ou igual à RCL (dívida < ou = RCL), não declarou apoio público ao PDRAE (4 dos 7 governadores do grupo). Ao mesmo tempo, a maior parte do grupo de governadores cujos estados tinham uma dívida maior do que RCL (dívida > RCL) declarou apoio público ao PDRAE (11 dos 20 governadores do grupo).

Contudo, é preciso ponderar uma possível relação direta entre endividamento estadual e apoio ao PDRAE, na medida em que tanto o grupo de estados, que tinha um nível de endividamento menor ou igual a RCL, assim como, o grupo de estados, que tinha uma dívida maior que a RCL, se dividem quase ao meio no que se refere ao apoio ao PDRAE. 
Isto é, o número de governadores, que apoiou ativamente o PDRAE, dentro do grupo de estados que tinham uma dívida estadual maior do que a sua RCL, representa apenas $55 \%$ dos estados desse grupo. Por outro lado, dentro do grupo de estados que tinham uma dívida estadual menor ou igual à sua RCL, o percentual de governadores que não apoiou ativamente o PDRAE é de 57,1\%.

Portanto, a relação entre situação fiscal do estado e apoio ativo do governador ao PDRAE não pode ser inferida tão facilmente $a$ priori.

Examinemos a relação entre a variável cumprimento da Lei Camata e apoio ativo do governador ao PDRAE.

\section{Quadro 6}

\section{Cumprimento da Lei Camata (1995-1997) * Apoio do Governador ao PDRAE Crosstabulation}

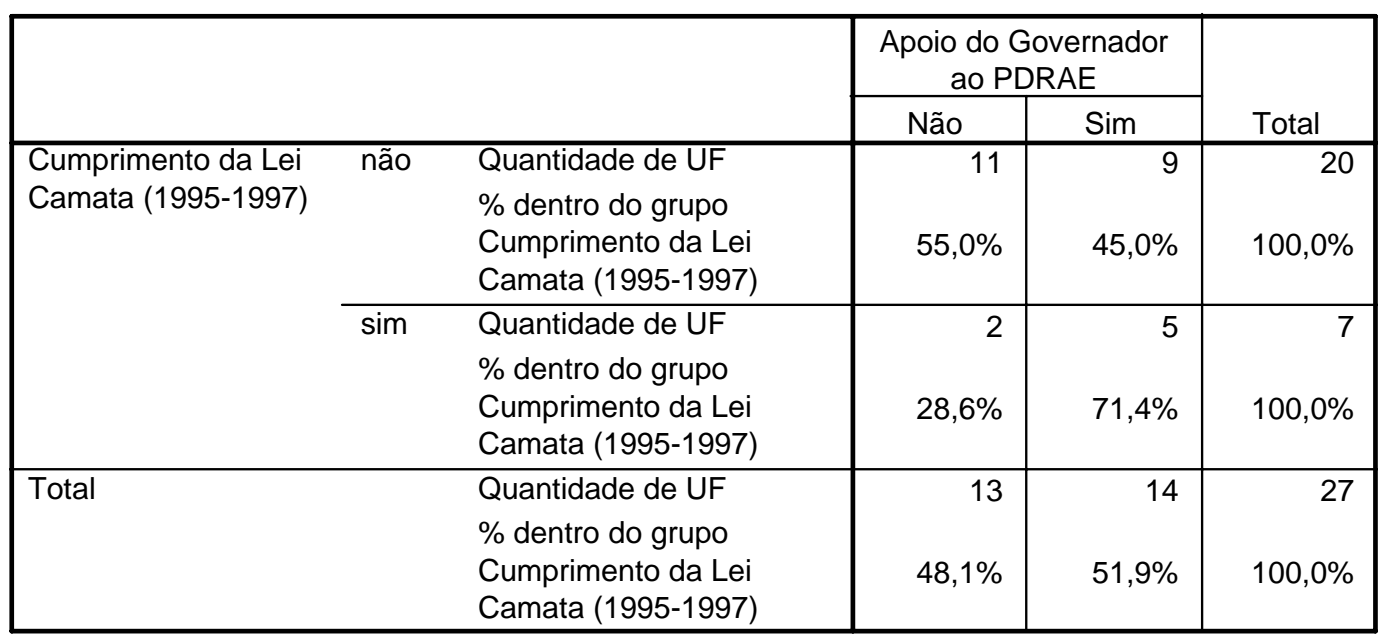

No Quadro 6, é possível observar que - assim como a relação entre endividamento e apoio - a relação sugerida pelos estudos, que alegaram que o descumprimento da Lei Camata foi um dos fatores que teria influenciado o apoio dos governadores ao PDRAE (Gaetani, 2000; Abrucio e Costa, 1999), também deve ser ponderada. 
Primeiramente, podemos ver - a exemplo do que ocorreu no Quadro 5 - que o grupo de estados que não estava cumprindo a Lei Camata entre 1995-1997 divide-se quase eqüitativamente no que se refere ao apoio ao PDRAE.

Contudo, ao contrário do que deveríamos esperar dentro desse grupo de governadores, mais da metade deles não apoiou ativamente (11) - enquanto apenas 45\% deste grupo apoiou o PDRAE (9).

Portanto, dentro desse grupo de governadores (que não estavam cumprindo a Lei Camata), o maior número de governadores se situa entre os que não apoiaram ativamente a reforma do governo FHC.

Alternativamente, vemos que a grande maioria do grupo de estados que estava cumprindo a Lei Camata apoiou ativamente o PDRAE. (71,4\% dos governadores, que estavam cumprindo a Lei Camata).

Nesse sentido, ponderando pelo número de governadores que estavam cumprindo ou não a Lei, vemos que, em termos relativos, a maior parte do apoio ativo veio - em contradição com a explicação apresentada pela literatura justamente do grupo de governadores que estava, em média, cumprindo a Lei Camata entre os anos de 1995 e 1997. (45\% dos governadores, que estavam descumprindo a Lei, apoiaram; enquanto $28,6 \%$ dos governadores, que estavam cumprindo a lei, não apoiou). ${ }^{54}$

Portanto, não descartamos aqui que o descumprimento da Lei Camata pode ter motivado alguns governadores a apoiarem ativamente o PDRAE, porém esse fato não fez com que a maior parte dos governadores apoiassem ativamente o PDRAE e,

\footnotetext{
${ }^{54}$ Os números dos governadores, que estavam descumprindo a Lei e apoiaram e dos governadores, que estavam cumprindo a lei e não apoiaram para cada um dos anos são, respectivamente, os seguintes: 1995 (54,2\% e 66,7\%); 1996 (47,4\% e 37,5\%) e 1997 (46,2\% e 42,9\%).
} 
tampouco, foi uma influência "generalizada" entre todos governadores ou, no limite, que seria suficiente para explicar o apoio ativo dos governadores ao PDRAE. ${ }^{55}$

Se, por um lado, o apoio ativo dos governadores ao PDRAE, de acordo com os cálculos feitos, guardaria pouca relação com a situação fiscal e financeira dos Estados, por outro, podemos verificar se a situação dos estados tem alguma relação com o fato dos governadores terem proposto programas estaduais de reforma.

Ou seja, pretendemos saber aqui se é possível dizer que os governadores que propuseram, em média, maior quantidade de programas próprios de reforma administrativa tinham de fato a necessidade de diminuir o quadro de funcionários do seu Estado - i. e., estavam descumprindo a Lei Camata -; ${ }^{56}$ ou, alternativamente, se os governadores, que propuseram programas próprios de reforma, não estavam enfrentando problemas com a Lei entre os anos de 1995 e $1997 .{ }^{57}$

\footnotetext{
${ }^{55} \mathrm{O}$ fato de não ter tido uma influência "generalizada" não significa dizer que o descumprimento da Lei Camata não influenciou a decisão de nenhum dos governadores em relação a apoiar ou não o PDRAE. O que estamos argumentando aqui é que pode ter sim existido influência, porém ela não é suficiente para explicar o apoio do governador ao PDRAE.

${ }^{56}$ Adotamos aqui a variável Cumprimento da Lei Camata e não Razão dívida/RCL, pois para comparar as médias é necessário que uma das variáveis indique grupos. Portanto, uma das variáveis utilizadas para comparar médias deve ter valores discretos.

${ }^{57}$ O cruzamento da variável referente ao endividamento dos Estados (dívida estadual maior que a RCL) com a variável quantidade de programas estaduais de reforma administrativa não corrobora a hipótese mais plausível. Ou seja, os Estados que tinham uma dívida estadual maior que a RCL (mais endividados) propuseram, em média, menos programas de reforma estaduais (2,6 programas) do que os governadores, que tinham uma dívida estadual menor ou igual que a RCL (2,71 programas). Entretanto, optamos por não apresentar aqui o cruzamento dessas duas variáveis, pois os resultados desse cálculo não
} 


\section{Quadro 7}

Quantidade de Programas Estaduais de Reforma Administrativa

\begin{tabular}{|l|r|r|r|}
\hline Cumprimento da Lei & $\begin{array}{c}\text { Média de } \\
\text { Programas } \\
\text { Camata (1995-1997) }\end{array}$ & & Estaduais \\
não & 1,85 & Nesvio- \\
sim & 4,86 & 7 & 2,207 \\
Total & 2,63 & 27 & 3,336 \\
\hline
\end{tabular}

No Quadro 7, os governadores, que não estavam cumprindo a Lei Camata durante o período de 1995 a 1997, propuseram, em média, 61,93\% [(4,86-1,85)/4,86] de programas estaduais de reforma administrativa a menos que os governadores, que estavam cumprindo a lei em questão.

Além disso, a dispersão na quantidade de programas estaduais de reforma administrativa é maior - em termos relativos (desvio-padrão/média) - no grupo, que não estava cumprindo a Lei Camata $(1,19)$, do que no grupo que estava cumprindo e propôs, em média, maior número de programas próprios $(1,10)$.

Portanto, vemos que os governadores, que se empenharam, em média, mais em ajustar por conta própria as finanças do seu Estado, são paradoxalmente aqueles que precisavam relativamente menos de ajuste das suas contas.

A última relação que os dados da Tabela 5 nos permitem realizar é entre a quantidade de programas estaduais de reforma administrativa propostos pelo grupo de governadores, que apoiou a reforma do governo FHC, em relação ao grupo, que não apoiou ativamente a iniciativa do governo federal. Pretendemos verificar, especialmente, se aqueles governadores, que apoiaram ativamente o PDRAE, propuseram, em média, maior quantidade de programas.

foram significativamente distintos entre os dois grupos e, além disso, esses cálculos não iriam acrescentar muito à explicação a ser exposta abaixo no Quadro 7. 


\section{Quadro 8}

Quantidade de Programas Estaduais de Reforma Administrativa
\begin{tabular}{|l|r|r|r|}
\hline Apoio do Governador & Média & N & Desvio-Padrão \\
\hline Não & 1,62 & 13 & 2,663 \\
Sim & 3,57 & 14 & 3,917 \\
Total & 2,63 & 27 & 3,455 \\
\hline
\end{tabular}

O Quadro 8 mostra que os governadores, que apoiaram ativamente o PDRAE, propuseram, em média, maior quantidade de programas próprios de reforma $(3,57)$ do que os governadores, que não apoiaram a reforma federal $(1,62)$.

O grupo de governadores, que não apoiou o PDRAE, propôs, em média, 54,62\% [(3,57-1,62)/3,57] de programas estaduais de reforma a menos que os governadores, que apoiaram ativamente o executivo federal. Desse modo, há uma diferença representativa em relação à quantidade de programas propostos pelos governadores, que apoiaram, comparada aos que não apoiaram o PDRAE.

Além disso, a dispersão em torno da média de programas estaduais de reforma é relativamente menor no grupo de governadores que apoiou (desvio-padrão/média = 1,10) do que no grupo que não apoiou a reforma do governo federal (desviopadrão/média $=1,64)$.

Portanto, isso quer dizer que, além do fato dos governadores que apoiaram o PDRAE tenham proposto, em média, um número consideravelmente maior de programas próprios de reforma; os governadores desse grupo também apresentaram quantidades mais homogêneas de programas próprios de reforma - se comparado ao grupo de governadores, que não apoiou o PDRAE.

Uma explicação hipotética - e que, portanto, exigiria uma análise mais aprofundada dos dados - é a de que pelo fato de - conforme observamos no Capítulo 1 - diversos programas estaduais de reforma administrativa terem sido fracassados (FSP), 
os governadores estaduais passaram a apoiar ativamente o PDRAE como forma alternativa para reformar a administração pública dos seus Estados.

Ou seja, os governadores estaduais mais engajados ${ }^{58}$ em reformar os seus Estados - que propuseram, em média, maior quantidade de programas estaduais - foram frustrados nas suas respectivas tentativas e passaram a apoiar ativamente o PDRAE para poderem reformar a administração do seu Estado de uma outra maneira.

Evidentemente, nesse grau de generalização analítica, é impossível fazer uma afirmação definitiva. Entretanto, o argumento em questão é que a relação deduzida no Capítulo 1, a partir de informações coletadas em diferentes fontes, - qual seja, (i) o fato de que houve a proposição de numerosos programas estaduais de reforma (Abrucio e Costa, 1999); (ii) que foi constatado que diversos desses programas estaduais fracassaram (FSP) e, portanto, (iii) os governadores aumentaram os seus incentivos para apoiar ativamente o PDRAE - não é, ao contrário dos outros argumentos tratados acima, negada pelos cálculos feitos aqui.

Por fim e a partir de uma outra perspectiva, poderíamos relacionar também o apoio ativo dos governadores ao PDRAE com as variáveis que se referem, não à situação financeira e fiscal dos Estados, mas sim às características das bancadas estaduais de deputados federais.

Relacionamos então as duas variáveis independentes da Tabela 4 (Tamanho da

\section{Bancada e Peso dos Partidos da Coalizão Ampliada de FHC na Bancada Estadual) com apoio ativo do governador ao PDRAE.}

A partir dessas relações, definimos a hipótese de que os governadores, que deram apoio ativo à reforma administrativa do governo FHC, o fizeram deliberadamente

\footnotetext{
${ }^{58}$ Seriam os "mais engajados" e não, necessariamente, os que mais precisavam, pois, vimos nos quadros anteriores que o apoio ativo ao PDRAE não veio exclusivamente - e, no limite, majoritariamente - dos governadores que mais precisavam ajustar as suas contas (dívida maior que RCL e descumprimento da Lei Camata).
} 
com o objetivo de reverter as "características negativas" da bancada de deputados federais eleitos pelo seu estado.

Em outros termos, partimos do pressuposto que interessava a todos os governadores estaduais a aprovação da reforma administrativa federal. ${ }^{59}$ Porém, os governadores, que apoiaram ativamente a reforma, o fizeram com o objetivo de informar explicitamente a sua preferência aos deputados federais de sua bancada estadual. Portanto, os governadores que seriam os "primeiros" a manifestar apoio ativo ao PDRAE, deveriam ser aqueles:

(i) cuja bancada de deputados federais eleitos pelo seu Estado fosse mais numerosa e, portanto, mais difícil de coordenar ${ }^{60} \mathrm{e} / \mathrm{ou}$

(ii) cujo peso dos partidos da coalizão ampliada do governo FHC na bancada estadual fosse mais baixo e, portanto, o governador estadual apoiaria publicamente o PDRAE para incentivar os membros de outros partidos de sua bancada estadual a votar com o executivo federal.

Em suma, a hipótese aqui é a de que os governadores apoiaram ativamente o PDRAE a fim de coordenar a sua bancada na votação e esse "esforço” dos governadores

\footnotetext{
${ }^{59}$ Partimos do pressuposto aqui que interessava a todos os governadores estaduais à aprovação da reforma administrativa, sobretudo, porque não encontramos informações sobre algum governador estadual que tivesse se oposto publicamente à reforma administrativa do governo FHC. Ao contrário disso, encontramos informações dizendo que mesmo governadores eleitos por partidos de oposição ao governo FHC apoiaram as medidas do programa de reforma federal. ("A reforma em outros estados", FSP, 16/01/96; "Executiva do PT apóia Vitor Buaiz no ES”, FSP, 11/06/96; "Cristóvam apóia demissões", FSP, 30/10/95). Portanto, rejeitamos a hipótese de que o não-apoio de um governador ao PDRAE estivesse relacionado com opinião contrária deste ator à iniciativa do governo federal. Consideramos que o não-apoio do governador ao PDRAE estava relacionado com o fato desse governador entender que o apoio público ao PDRAE não era necessário ou ainda devido à falta de dados ou informações sobre o apoio desses governadores.

${ }^{60}$ Aqui a hipótese de que o apoio do governador ao PDRAE vir de um Estado cuja bancada de deputados estaduais fosse mais numerosa poderia estar relacionada com o modo pelo qual os dados sobre o apoio do governador ao PDRAE foram coletados. Ou seja, como uma das fontes utilizadas para construir essa variável foi a imprensa (FSP) é possível que os dados utilizados para construir essa variável sejam referentes principalmente aos Estados politicamente "mais relevantes" com uma bancada de deputados mais numerosa em detrimento dos Estados que detém menor "importância” política com uma bancada de deputados federais menos numerosa.
} 
teria mais sentido nos estados onde seria mais difícil a bancada votar favoravelmente no projeto de reforma federal. ${ }^{61}$

\section{Quadro 9}

\begin{tabular}{|c|c|c|c|}
\hline \multicolumn{2}{|c|}{$\begin{array}{l}\text { Apoio do Governador } \\
\text { ao PDRAE }\end{array}$} & $\begin{array}{c}\text { Tamanho } \\
\text { da Bancada }\end{array}$ & $\begin{array}{l}\text { Peso dos } \\
\text { Partidos da } \\
\text { Coalizão } \\
\text { Ampliada de } \\
\text { FHC na } \\
\text { Bancada } \\
\text { Estadual (\%) }\end{array}$ \\
\hline \multirow[t]{3}{*}{ Não } & Média & 11,62 & 87,52 \\
\hline & $\mathrm{N}$ & 13 & 13 \\
\hline & Desvio-Padrão & 5,55 & 13,84 \\
\hline \multirow[t]{3}{*}{ Sim } & Média & 25,86 & 76,00 \\
\hline & $\mathrm{N}$ & 14 & 14 \\
\hline & Desvio-Padrão & 19,85 & 13,57 \\
\hline \multirow[t]{3}{*}{ Total } & Média & 19,00 & 81,55 \\
\hline & $\mathrm{N}$ & 27 & 27 \\
\hline & Desvio-Padrão & 16,24 & 14,66 \\
\hline
\end{tabular}

O Quadro 9 mostra que os governadores, que apoiaram a reforma administrativa do governo federal governam Estados que têm uma bancada de deputados federais, em média, consideravelmente mais numerosa $(25,86)$ e em que os partidos da coalizão ampliada de FHC tinham, em média, também um considerável peso menor (76\%) se comparado às bancadas dos estados onde os governadores não apoiaram publicamente o PDRAE (11,62 e 87,53\%, respectivamente).

Entretanto, a dispersão tanto dos valores do tamanho da bancada como do peso dos partidos da coalizão ampliada é maior, em termos relativos (desviopadrão/média), dentro do grupo de governadores que apoiou o PDRAE $(0,77$ e 0,19,

\footnotetext{
${ }^{61}$ Em última instância, para definir essa hipótese estamos nos apoiando aqui no raciocínio de backwards induction - i. e., os governadores, conhecendo as características da bancada de deputados federais eleitos pelo seu Estado, se antecipariam e apoiariam ativamente o PDRAE nos Estados cuja bancada tem características que dificultariam a coordenação e votação favorável ao projeto (bancada numerosa e com
} 
respectivamente), do que dentro do grupo de governadores que não apoiou (0,48 e 0,16, respectivamente).

Mesmo assim, dada a considerável diferença entre as médias do tamanho da bancada (14 ou 55,07\% de deputados federais a menos, em média, nas bancadas dos Estados cujo governador não apoiou a reforma) e do peso dos partidos da coalizão ampliada (11,52 pontos percentuais a mais, em média, de peso dos partidos da coalizão nas bancadas dos Estados cujo governador não apoiou a reforma) entendemos que é possível, pelo menos, sugerir que: o fato dos governadores terem se pronunciado favoravelmente ao PDRAE poderia ser decorrente da tentativa deste ator tentar reverter às características "negativas" da composição da bancada estadual de deputados federais (bancada numerosa e mais difícil de coordenar e menor peso dos partidos da "coalizão ampliada” do governo FHC). ${ }^{62}$

A explicação do apoio pela via das variáveis referentes às características da bancada de deputados ganha ainda relevância, na medida em que, conforme observamos anteriormente, as variáveis relacionadas à situação fiscal e financeira dos estados apresentaram uma relação menor com o apoio ativo dos governadores ao PDRAE do que as variáveis associadas às características da bancada.

Em resumo, nessa seção vimos que a necessidade de ajustar as contas estaduais - i. e., dívida maior que a RCL e descumprimento da Lei Camata - não se traduziu

peso pequeno dos partidos da coalizão ampliada). Eles, em resumo, estariam agindo como os líderes dos partidos, que indicam voto para informar e coordenar a sua bancada.

${ }^{62}$ Como ressaltado nas notas de rodapé anteriores, as informações e os dados que coletamos aqui para construir as variáveis (em especial, a variável apoio ativo do governador ao PDRAE) não nos permite fazer uma afirmação conclusiva. Além disso, entendemos que para que pudéssemos afirmar que os governadores agiram no sentido de "reverter às características da composição da bancada de deputados federais eleitos pelo seu Estado” seria necessário evidenciar “o mecanismo que levou a” (Elster, 1994) e associado a isso mostrar evidências que indique que a motivação ou preferência dos governadores ao apoiar a reforma foi com essa intenção e não no sentido de, p. ex., apenas intensificar os incentivos que os deputados eleitos pelo seu Estado e também pertencentes aos partidos da coalizão de FHC tinham para votar na reforma administrativa. 
automaticamente nem em apoio ativo dos governadores ao PDRAE, nem, tampouco, em proposição de programas estaduais de reforma administrativa.

De um lado, observamos que os governadores, que apoiaram ativamente a reforma administrativa federal, propuseram, em média, maior número de programas próprios de reforma (Quadro 8).

No entanto, por outro lado, tanto os governadores que apoiaram ativamente o PDRAE, como principalmente os governadores que propuseram, em média, maior quantidade de programas próprios de reforma foram (em termos relativos), paradoxalmente, os que precisavam menos - i. e., estavam, em média, cumprindo a Lei Camata entre os anos de 1995 e 1997.

Nesse contexto, resta, por fim, saber então se de fato o apoio do governador à iniciativa do governo FHC surtiu o efeito esperado. Isto é, pretendemos indicar na última seção desse capítulo quais são as variáveis que explicam a coesão das bancadas estaduais e, especialmente, se os governadores conseguiram, através do apoio público ao PDRAE, fazer com que os seus deputados votassem de maneira mais coesa. ${ }^{63}$

Analisaremos quais são as variáveis que condicionaram o grau de coesão encontrado nas bancadas de deputados federais das vinte e sete unidades federativas apresentadas na Tabela 4 e, posteriormente, na parte final do presente trabalho, faremos as considerações finais acerca da coesão das bancadas estaduais conjugada à fidelidade dos deputados à indicação de voto do líder do seu partido.

\footnotetext{
${ }^{63}$ É necessário relembrar aqui que, como dito anteriormente, partimos do pressuposto de que para que os governadores estaduais tivessem um papel ou influência importante nas votações da reforma administrativa, eles teriam que, antes de tudo, contar com uma bancada de deputados federais que votassem com um grau razoável de unidade.
} 
Análise do papel dos governadores estaduais na votação do PEC 173

Antes de proceder à análise da coesão das bancadas, propriamente dita, seria interessante fazer aqui algumas considerações sobre a coesão da bancada estadual nas votações do PEC 173 que foram mais problemáticas para o governo - i. e., as duas votações em que o líder do governo indicou voto e perdeu (estabilidade dos futuros servidores e subteto) e as duas votações que conseguiu apenas os 308 votos necessários para aprovação (substitutivo da comissão e DVS n. 40 - estabilidade).

Dentre essas quatro votações problemáticas, podemos ver que duas delas se referem a um ponto de especial interesse para os governadores estaduais - i. e., a flexibilização da estabilidade dos funcionários públicos. (Abrucio e Costa, 1999; Melo 2002; Gaetani, 2000; Gaetani e Heredia, 2002).

Além dessas duas votações, podemos indicar aqui também a fixação do subteto para remuneração dos servidores públicos estaduais e municipais como um ponto especialmente interessante aos governadores estaduais. Analisamos, portanto, a coesão da bancada estadual nessa votação, na medida em que essa matéria também se refere aos Estados.

Nesse sentido, analisamos então a média da coesão das bancadas estaduais nessas votações problemáticas e que também seriam pontos da reforma administrativa do governo FHC de especial interesse para os governadores. Verificamos a coesão das bancadas estaduais na votação (i) que permitia a contratação de servidores públicos sem estabilidade; (ii) do DVS n. 40 e também; (iii) na votação da matéria referente à possibilidade dos estados e municípios fixarem um subteto para remuneração dos seus funcionários.

Na votação da matéria que permitia a contratação futura de funcionários sem estabilidade - a qual foi uma das duas votações que o executivo não conseguiu 
assegurar maioria qualificada para sua aprovação -, a média ponderada da coesão das bancadas estaduais ficou em $64,91 \%$.

Já na votação do DVS n. 40 - também referente à estabilidade dos funcionários públicos e que o governo conseguiu aprovar apenas com os 308 votos necessários - a média ponderada da coesão das bancadas estaduais ficou em $66,27 \%$.

Por fim, na votação do subteto para remuneração dos funcionários públicos dos estados e municípios, a média ponderada da coesão ficou em $\mathbf{6 6 , 6 8 \% . ~}$

Portanto, nestas três votações que refletiam pontos de especial interesse dos governadores, a média da coesão das bancadas estaduais (64,91\%, 66,27\%, 66,68\%) ficou bem abaixo da própria média da coesão durante as trinta e sete votações $(73,96 \%)^{64}$

Feitas essas considerações iniciais sobre a votação do PEC 173, passaremos agora à análise da coesão média da bancada estadual.

Com três das seis variáveis independentes, que apresentamos nas Tabelas 4 e 5, montamos um modelo explicativo da coesão média dos estados. ${ }^{65}$ Nesse modelo, colocamos como variáveis explicativas da coesão média das bancadas estaduais: o (i) tamanho da bancada; (ii) peso dos partidos da "coalizão ampliada" de FHC na bancada estadual (\%); (iii) apoio ativo do governador ao PDRAE. ${ }^{66}$

\footnotetext{
${ }^{64}$ Na votação do substitutivo da comissão, a outra votação da reforma administrativa que foi problemática para o governo, a média ponderada da coesão das bancadas estaduais também ficou bem abaixo da média geral $(62,13 \%)$.

${ }^{65}$ Optamos por excluir do modelo as outras três variáveis explicativas (dívida estadual/RCL; Média da Razão Despesa Total com Pessoal/Receita Corrente Líquida_1995 a 1997 (\%) e; quantidade de programas estaduais de reforma administrativa), pois a influência dessas variáveis sobre a coesão média da bancada estadual é intermediada pela variável apoio ativo do governador ao PDRAE. Mesmo assim, foram realizados testes com a inclusão dessas três variáveis no modelo explicativo da coesão média. Contudo, nenhuma destas variáveis apresentou significância estatística suficiente, assumindo um erro de $5 \%$.

${ }^{66} \mathrm{O}$ cálculo da correlação entre essas três variáveis explicativas mostrou correlações estatisticamente significantes, assumindo um erro de 5\%, entre: (i) tamanho da bancada e apoio do governador ao PDRAE $(0,447)$ e (ii) peso dos partidos da coalizão na bancada estadual e apoio do governador ao PDRAE $(-0,400)$. A correlação entre tamanho da bancada e peso dos partidos da coalizão ampliada não foi estatisticamente significante.
} 
Ao fazer uma regressão linear com essas três variáveis explicativas da coesão estadual média, esperaríamos que uma maior coesão estadual fosse explicada por:

(i) uma bancada pequena, pois consideramos que a coordenação dos votos dos parlamentares em uma bancada é dificultada quanto maior for o número de parlamentares que integram esta (relação negativa com a coesão);

(ii) um grande peso dos partidos da "coalizão ampliada” na bancada, tanto porque o projeto era do executivo federal - e, portanto, este tentaria em tese incentivar, principalmente, os parlamentares dos partidos da sua coalizão para aprovação da reforma administrativa -; como porque o maior peso da coalizão sobre a bancada significaria uma menor divisão da bancada estadual entre parlamentares de diversos partidos políticos (relação positiva com a coesão);

(iii) apoio ativo do governador ao PDRAE, pois consideramos que um governador interessado em ver a reforma administrativa aprovada se esforçaria para influenciar o maior número possível de deputados federais eleitos por seu estado a votar com o executivo federal (relação positiva com a coesão).

O resultado dessas relações hipotéticas pode ser sumarizado na seguinte expressão:

Coesão Estadual Média $=\beta_{0}-\beta_{1}$ (Tam. da Bancada $)+\beta_{2}$ (Peso da Coalizão $)+\beta_{3}$ (Apoio Ativo do Gov. ao PDRAE) $+\varepsilon$

Apresentamos abaixo os resultados da regressão linear feita para as votações da reforma administrativa do governo FHC em 1997. 


\section{Quadro 10}

\section{Sumário do Modelo}

\begin{tabular}{|l|r|r|r|r|}
\hline Model & $\mathrm{R}$ & $\begin{array}{c}\mathrm{R} \\
\text { quadrado }\end{array}$ & $\begin{array}{c}\mathrm{R} \\
\text { quadrado } \\
\text { ajustado }\end{array}$ & $\begin{array}{r}\text { Std. Error of } \\
\text { the Estimate }\end{array}$ \\
\hline 1 &, $814^{\mathrm{a}}$ &, 662 &, 618 & 4,45700 \\
\hline
\end{tabular}

a. Predictors: (Constant), Apoio do Governador ao PDRAE, Peso dos Partidos da Coalizão Ampliada de FHC na Bancada Estadual (\%), Tamanho da Bancada

O Quadro 10 mostra que 61,8\% ( $\mathrm{R}^{2}$ ajustado - coeficiente de determinação ajustado) da variação da coesão estadual média é explicada pela variação das três variáveis independentes incluídas no modelo. Portanto, consideramos desde já que estas três variáveis explicativas, em conjunto, apresentam um poder explicativo considerável da variação da coesão média estadual.

Dado isto, analisamos no Quadro 11 abaixo, qual dessas variáveis explicativas tem significância estatística (quando assumimos um erro de 5\%) e qual a relação entre estas e a coesão média estadual.

\section{Quadro 11}

Coeficientes $^{\mathrm{a}}$

\begin{tabular}{|c|c|c|c|c|c|c|}
\hline \multirow[b]{2}{*}{ Mode } & & \multicolumn{2}{|c|}{$\begin{array}{c}\text { Coeficientes } \\
\text { não-padronizados }\end{array}$} & \multirow{2}{*}{$\begin{array}{c}\begin{array}{c}\text { Coeficientes } \\
\text { padronizados }\end{array} \\
\text { Beta }\end{array}$} & \multirow[b]{2}{*}{$\mathrm{t}$} & \multirow[b]{2}{*}{ Sig. } \\
\hline & & B & Std. Error & & & \\
\hline \multirow[t]{4}{*}{1} & (Constant) & 50,880 & 6,073 & & 8,378 &, 000 \\
\hline & Tamanho da Bancada &,- 118 & ,061 &,- 265 & $-1,925$ & ,067 \\
\hline & $\begin{array}{l}\text { Peso dos Partidos da } \\
\text { Coalizão Ampliada de } \\
\text { FHC na Bancada } \\
\text { Estadual (\%) }\end{array}$ & ,344 & ,066 & ,699 & 5,203 & ,000 \\
\hline & $\begin{array}{l}\text { Apoio do Governador } \\
\text { ao PDRAE }\end{array}$ & ,259 & 2,014 & ,018 & ,129 & ,899 \\
\hline
\end{tabular}

a. Dependent Variable: Coesão Média da Bancada Estadual (\%) 
No Quadro 11, observamos, primeiramente, através dos coeficientes padronizados, que todas variáveis explicativas apresentaram a relação esperada com a variável-resposta coesão média da bancada estadual. Ou seja, tal como definimos acima, peso dos partidos da coalizão ampliada e apoio ativo do governador ao PDRAE apresentaram relação positiva e tamanho da bancada, relação negativa com a coesão média da bancada estadual.

Quando comparamos os coeficientes padronizados (Beta) das três variáveis explicativas, vemos ainda que a influência da variável peso da coalizão $(0,699)$ sobre a coesão média da bancada estadual é a maior dentre todas as variáveis explicativas colocadas no modelo.

Entretanto, quando observamos a significância estatística das três variáveis, vemos que apenas a variável explicativa peso dos partidos da coalizão ampliada de FHC na bancada estadual de deputados é estatisticamente significante, assumindo um erro de $5 \%$.

A variável tamanho da bancada tem uma significância estatística $(0,067)$ próxima do nível aceitável $(0,05)$ e, por outro lado, a variável apoio ativo do governador ao PDRAE apresentou uma baixíssima significância estatística $(0,899)$.

Formulamos então um outro modelo explicativo da coesão média excluindo essa última variável (apoio ativo do governador ao PDRAE) dos cálculos. O objetivo aqui é observar se há aumento na capacidade explicativa do modelo - i. e., se o coeficiente de determinação ( $\mathrm{R}^{2}$ ajustado) aumenta com a exclusão dessa variável de menor significância estatística. ${ }^{67}$

\footnotetext{
${ }^{67}$ Testamos também um modelo composto com todas as seis variáveis independentes para explicar a variável dependente desvio-padrão/coesão média (indicador 2). O objetivo dessa regressão linear era analisar se algumas dessas seis variáveis independentes explicavam a variação no grau de coesão de uma determinada bancada estadual ao longo das trinta e sete votações da reforma administrativa. Ou seja, nesse modelo esperávamos que uma menor dispersão da coesão da bancada estadual (menor valor de desvio-padrão/coesão média) fosse explicada por: (i) uma bancada pequena; (ii) maior peso dos partidos da coalizão; (iii) um valor elevado dívida/RCL; (iv) um valor elevado da Média da Razão Despesa Total
} 
No Quadro 12 abaixo, observamos que o modelo explicativo - montado apenas com as variáveis explicativas tamanho da bancada e peso dos partidos da coalizão ampliada de FHC na bancada estadual - apresentou um coeficiente de determinação um pouco maior que o modelo anterior (R quadrado ajustado aumentou de 61,8\% para $63,4 \%)$.

\section{Quadro 12}

Sumário do Modelo

\begin{tabular}{|l|r|r|r|r|}
\hline Model & $\mathrm{R}$ & $\begin{array}{c}\mathrm{R} \\
\text { quadrado }\end{array}$ & $\begin{array}{c}\mathrm{R} \\
\text { quadrado } \\
\text { ajustado }\end{array}$ & $\begin{array}{r}\text { Std. Error of } \\
\text { the Estimate }\end{array}$ \\
\hline 1 &, $814^{\mathrm{a}}$ &, 662 &, 634 & 4,36473 \\
\hline
\end{tabular}

a. Predictors: (Constant), Peso dos Partidos da Coalizão Ampliada de FHC na Bancada Estadual (\%), Tamanho da Bancada

Além disso, vemos no Quadro 13 abaixo que a variável explicativa tamanho da

bancada se encontra “no limite” da significância estatística assumindo um erro de 5\%.

com Pessoal/Receita Corrente Líquida_1995 a 1997; (v) uma maior quantidade de programas estaduais de reforma administrativa; (vi) apoio do governador ao PDRAE. No entanto, nenhuma dessas variáveis explicativas apresentou significância estatística assumindo o erro de 5\% e, além disso, o coeficiente de determinação do modelo ( $\mathrm{R}^{2}$ ajustado) ficou com um valor de 16,1\%. Com o mesmo “método" que utilizamos para ajustar o modelo da coesão média - i. e., retirar pari passu as variáveis independentes que tem menor significância estatística - chegamos a um modelo com duas variáveis explicativas (relação entre dívida/RCL e média da razão gasto com pessoal/RCL entre os anos de 1995 e 1997), cujo R $^{2}$ ajustado aumentou para $18,2 \%$. No entanto, apenas a variável média da razão gasto com pessoal/RCL entre os anos de 1995 e 1997 apresentou significância estatística, assumindo um erro de 5\%. Portanto, consideramos que um modelo para explicar a dispersão da coesão da bancada estadual durante as votações da reforma administrativa deve se basear em outras variáveis independentes. 


\section{Quadro 13}

\section{Coeficientes $^{\mathrm{a}}$}

\begin{tabular}{|c|c|c|c|c|c|c|}
\hline \multirow[b]{2}{*}{ Model } & & \multicolumn{2}{|c|}{$\begin{array}{c}\text { Coeficientes } \\
\text { não-padronizados }\end{array}$} & \multirow{2}{*}{$\begin{array}{c}\begin{array}{c}\text { Coeficientes } \\
\text { padronizados }\end{array} \\
\text { Beta } \\
\end{array}$} & \multirow[b]{2}{*}{$\mathrm{t}$} & \multirow[b]{2}{*}{ Sig. } \\
\hline & & $\mathrm{B}$ & Std. Error & & & \\
\hline & (Constant) & 51,170 & 5,522 & & 9,267 &, 000 \\
\hline & Tamanho da Bancada &,- 115 & ,056 &,- 258 & $-2,061$ & ,050 \\
\hline & $\begin{array}{l}\text { Peso dos Partidos da } \\
\text { Coalizão Ampliada de } \\
\text { FHC na Bancada } \\
\text { Estadual (\%) }\end{array}$ & ,341 & ,062 & ,693 & 5,535 & ,000 \\
\hline
\end{tabular}

a. Variável Dependente: Coesão Média da Bancada Estadual (\%)

No modelo explicativo acima, vemos que o peso da coalizão continua estatisticamente significante, já a variável tamanho da bancada aumentou a sua significância estatística em relação ao modelo anterior, mas, entretanto, encontra-se no limite do erro de $5 \%$.

Além disso, através dos coeficientes padronizados, observamos, em primeiro lugar, que o peso da coalizão continua a ter a maior influência sobre a coesão média (beta $=0,693)$.

Utilizando, por fim, os coeficientes não-padronizados das variáveis explicativas, podemos inferir que:

(i) o aumento de um deputado em uma determinada bancada estadual tendeu a diminuir, em média, $\mathbf{0 , 1 1 5}$ ponto percentual na coesão média dessa mesma bancada ao longo da votação da reforma administrativa; e

(ii) o aumento de um ponto percentual na participação de deputados da coalizão ampliada de FHC na bancada estadual tendeu a aumentar, em média, 0,341 ponto percentual a coesão média desta mesma bancada estadual. 
Nesse sentido, podemos sugerir uma bancada estadual hipotética composta por (i) 10 deputados federais (tamanho da bancada $=10$ deputados) sendo que (ii) 8 deles pertenciam a algum dos partidos que faziam parte da “coalizão ampliada” de FHC (peso dos deputados do PPB, PFL, PTB, PMDB, PSDB na bancada estadual $=80 \%$ ) e dizer que, de acordo com esses cálculos, essa bancada hipotética tendeu a ter, em média, uma coesão média de, aproximadamente, 77,3\% [51,17 - 0,115 (10) + 0,341 (80\%)] durante a votação da reforma administrativa do governo FHC.

Em resumo, portanto, de acordo com os nossos cálculos, o que importou para explicar a variação da coesão dos deputados federais de uma bancada estadual não foi a variável relacionada à preferência do governador (apoio ativo do governador estadual ao PDRAE).

Diferentemente da idéia de que os governadores importaram nas votações da reforma administrativa, podemos dizer que o poder que o governador estadual poderia ter tido nas votações da reforma administrativa - i. e., uma bancada de deputados federais, que votassem com elevado grau de coesão - dependeu, na verdade, das características da composição da bancada estadual. Características essas associadas, sobretudo, à composição partidária da bancada estadual.

Por fim, podemos analisar qual seria a relação existente entre o fato do governador apoiar ativamente a reforma administrativa federal e a coesão média da bancada de deputados federais eleitos pelo seu estado. Em outros termos, construímos o Quadro 14 abaixo, a fim de observar qual seria a relação entre essas duas variáveis se ela fosse estatisticamente significante. 


\section{Quadro 14}

Coesão Média da Bancada Estadual (\%)
\begin{tabular}{|l|c|r|r|}
\hline $\begin{array}{l}\text { Apoio do Governador } \\
\text { ao PDRAE }\end{array}$ & $\begin{array}{c}\text { Média de } \\
\text { Coesão }\end{array}$ & N & Std. Deviation \\
\hline Não & 79,60 & 13 & 8,04 \\
Sim & 74,22 & 14 & 5,42 \\
Total & $76,81^{\mathrm{a}}$ & 27 & 7,21 \\
\hline
\end{tabular}

a. Essa média é o valor calculado sem ponderar pelo número de cadeiras que cada uma das bancadas estaduais detém na Câmara dos Deputados.

No Quadro 14, observamos que a média da coesão da bancada do estado cujo governador declarou apoio público ao PDRAE (74,22\%) é mais de 5 pontos percentuais menor que a coesão entre os deputados eleitos pelo estado que o governador não declarou apoio público à reforma administrativa do governo federal $(79,60 \%)$.

Ou seja, tomando os resultados desse quadro para demonstrar qual seria a relação entre apoio ativo do governador ao PDRAE e coesão média, é possível argumentar que o fato do governador ter declarado apoio à reforma administrativa federal estaria associado - não a uma bancada de deputados que votassem de maneira coesa -, mas sim a uma bancada de deputados federais que votasse, em média, mais fragmentada.

Isto é, de acordo com os cálculos, o governador teria mais chance de ter uma influência efetiva nas votações da reforma administrativa - i. e., uma bancada de deputados mais coesa - se, paradoxalmente, permanecesse "calado" ao invés de apoiar ativamente a reforma administrativa. 


\section{Conclusão}

Nesse trabalho, examinamos as negociações, a tramitação e, principalmente, a votação da reforma administrativa do governo FHC. Concluímos que o executivo federal obteve uma elevada taxa de sucesso nas votações da reforma administrativa (ganhou 94\% das votações em que o líder do governo indicou voto.

Além disso, vimos que uma parte considerável desse sucesso é explicada pela considerável disciplina partidária dos partidos pertencentes à coalizão de governo (média ponderada da disciplina do PSDB, PFL, PTB, PPB, PMDB = 83,3\%).

Dentre os partidos dessa coalizão, vimos ainda que o PFL foi o que mais se destacou tanto pela disciplina média dos seus deputados (em torno de 90\%) como pela estabilidade desta taxa de disciplina ao longo das 37 votações analisadas.

Dessa maneira, indicamos que o fato do PFL ser composto em grande parte por deputados provenientes da "elite do funcionalismo público” poderia ter contribuído para explicar esse elevado apoio à reforma administrativa do governo FHC. Ou seja, embora as negociações com as entidades que representam os funcionários públicos em geral tenham fracassado, a participação de parte desse funcionalismo (a "elite do funcionalismo”) não pode ser descartada a priori na outra fase que compõe o processo de reforma (votação).

Entretanto, mesmo essa considerável contribuição dada pelo PFL - e dos partidos da base aliada ao governo FHC em geral - à votação da reforma, não impediu que o governo enfrentasse dificuldades para aprovar alguns pontos importantes e altamente controversos do projeto de reforma em questão.

Em duas votações, referentes à flexibilização da estabilidade e à que permitia aos estados e municípios fixar subteto de remuneração para os seus funcionários - além 
da votação referente ao substitutivo da comissão -, o governo enfrentou dificuldades e/ou não conseguiu aprovação.

Ironicamente, essas votações são referentes a temas que os estudos indicaram como de interesse prioritário para os governadores estaduais. No entanto, a despeito do interesse dos governadores, pudemos observar que os deputados federais se dividiram bastante nessas votações, divergindo tanto no que se refere ao seu partido como também em relação à bancada estadual (a coesão das bancadas estaduais nessas três votações ficou em torno de 65\%, portanto, bem abaixo da média de coesão verificada para todas as votações, 73,96\%).

A respeito do apoio ativo dos governadores ao PDRAE, vimos que a literatura explicou o apoio dos governadores estaduais à reforma a partir de distintas relações. De acordo com estes argumentos, pudemos observar que incentivos para os governadores apoiarem a reforma administrativa federal não faltaram.

Isto é, o apoio dos governadores ao PDRAE foi atribuído , principalmente, ao fato que a reforma administrativa federal poderia propiciar (i) a liberação de recursos gastos com pagamento de pessoal; (ii) o cumprimento da Lei Camata e (iii) a abertura de canais de renegociação das dívidas estaduais com a União. Portanto, em última instância, esses incentivos estariam relacionados, sobretudo, ao estado fiscal dos estados.

Entretanto, relacionando a posição dos governadores com as variáveis referentes ao endividamento dos estados e aos gastos com pagamento dos servidores públicos estaduais (cumprimento da Lei Camata), vimos que o apoio ativo dos governadores não pode ser deduzido diretamente da situação fiscal dos estados.

Na seção referente à análise do apoio dos governadores ao PDRAE, chegamos à conclusão de que a necessidade de ajustar as contas estaduais - i. e., estados cuja dívida 
era maior que a receita líquida corrente e/ou que estavam gastando mais de 60\% desta receita em pagamento de pessoal - não se traduziu automaticamente em apoio ativo do governador ao PDRAE e, tampouco, em proposição de programas próprios de reforma administrativa.

Após traçarmos essas relações com o apoio ativo do governador ao PDRAE, passamos ao teste da influência desta variável sobre a coesão da bancada de deputados federais eleitos por um mesmo estado.

Vimos que o apoio ativo do governador ao PDRAE não foi estatisticamente significante para explicar a coesão média das bancadas estaduais.

Além disso, observamos também que se existisse alguma relação entre o apoio do governador ao PDRAE e a coesão média da bancada estadual, essa relação não seria positiva, pois o apoio ativo do governador ao PDRAE esteve associado a uma menor coesão média da bancada estadual.

Ora, de acordo com o argumento apresentado nesse trabalho, seria necessário que os deputados federais eleitos no estado votassem com um mínimo de unidade para que o governador pudesse ter algum poder nas votações do legislativo federal.

No entanto, o que acontece é justamente o contrário. Isto é, a bancada estadual de deputados federais esteve mais dividida nas situações em que o governador estadual revelou o seu apoio à reforma administrativa do governo FHC.

Uma situação hipotética para explicação desses resultados poderia ser a de que pelo fato das bancadas estaduais serem compostas por diferentes partidos políticos; quando o governador estadual - que pertence a um determinado partido político orienta os deputados federais do seu estado a votarem em determinada matéria na Câmara dos Deputados, ele acaba dividindo a bancada. 
Nesse sentido, quando o governador revela a sua preferência, os deputados do seu partido o seguem enquanto os deputados dos partidos de oposição a ele votam contrariamente. Resultando, portanto, em uma baixa coesão na bancada estadual.

Ora, se essa situação ocorresse de fato, a clivagem seria partidária e não estadual. Isso mostraria justamente que a lealdade dos congressistas não seria em relação ao estado como propõem Abrucio e Samuels (1997 apud Abrucio e Costa, 1999, p. 14) e sim, em relação ao partido político ao qual pertencem.

Na verdade, conforme pudemos ver acima, a despeito do apoio ativo do governador ao PDRAE, o que influenciou e condicionou o grau de coesão dos deputados foram os fatores associados às características numéricas e, principalmente, partidárias da composição da bancada estadual.

Por fim, a comparação da taxa de disciplina partidária com o grau de coesão estadual - ambos referentes às mesmas votações da reforma administrativa - também não corroboram o argumento que os deputados federais são mais leais aos governadores dos estados pelos quais foram eleitos do que pelos partidos políticos aos quais fazem parte.

Ou seja, embora o grau de coesão estadual (tal como o calculamos) tende a ter um valor maior - i. e., varia no intervalo de 50\% a $100 \%$ - do que o índice de fidelidade do partido às indicações do seu líder - que pode variar no intervalo de 0 a 100\% -, o valor daquele índice (grau de coesão estadual) foi mais de 10 pontos percentuais menor do que o índice de fidelidade do partido às indicações do seu líder.

Encontramos uma média nacional de $\mathbf{8 4 , 8 6 \%}$ de disciplina partidária e 73,96\% de coesão estadual nas votações da reforma administrativa, sendo que houve uma variação maior na coesão das bancadas dos Estados (média do indicador 2 = 17,67) do 
que na disciplina dos parlamentares em relação aos seus partidos políticos (média do indicador $1=13,81)$.

Portanto, embora estes dados sejam insuficientes para sustentar uma proposição alternativa, acreditamos que eles permitem rejeitar as proposições que atribuem uma influência determinante do governador estadual nas votações da reforma administrativa do governo FHC.

Ou seja, a partir da análise feita, pudemos ver que a influência maior nas votações do legislativo federal parece ocorrer dentro dessa esfera, através dos líderes partidários nacionais e entre os partidos que apóiam ou não o executivo - e não pela via da relação dos governadores estaduais com suas bancadas.

Concluímos, assim que os governadores podem ter contribuído nas votações, mas se de fato contribuíram, a fizeram pela via da organização partidária. 


\section{Referências Bibliográficas}

ABRUCIO, Fernando Luiz. (1997). "O impacto do modelo gerencial na administração pública: um breve estudo sobre a experiência internacional recente”. Cadernos ENAP, Brasília, n. 10.

\& COSTA, Valeriano M. F. (1999). "Reforma do Estado e o contexto federativo brasileiro”. Pesquisas, n. 12. Fundação Konrad Adenauer-Stiftung.

ABRUCIO, Fernando Luiz. \& SAMUELS, David. (1997). “A nova política dos governadores”. Lua Nova, n. 40/41, pp. 137-166.

ALVERGA, Carlos Frederico. (2003). "Levantamento teórico sobre as causas dos insucessos das tentativas de reforma administrativa". Revista do Serviço Público, ano 54, n. 3, pp. 29-45.

ANDREWS, Christina W. \& KOUZMIN, Alexander (1998a). "O discurso da nova administração pública”. Lua Nova, n. 45, pp. 97-130.

. (1998b). “’Dando nome à Rosa’: o discurso da nova administração pública no contexto brasileiro”. Artigo apresentado na XI Conferência Nacional da Public Administration Network realizada em Colorado Springs, EUA. 23p.

ANDREWS, Christina W.; COMINI, Graziella \& VIEIRA, Elenir H. (1999). "Continuities and change in Brazilian administrative reform". The International Journal of Public Sector Management, vol. 12, n. 6, pp. 482500.

ARRETCHE, Marta. (2002) "Federalismo e relações intergovernamentais no Brasil: a reforma de programas sociais”. Dados - Revista de Ciências Sociais, Rio de Janeiro, vol. 45, n. 3, pp. 431-458.

BACCARO, Lucio \& LOCKE, Richard. M. (1997). "Reforma do setor público e participação sindical: o caso do sistema de pensão italiano”. Revista do Serviço Público, ano 48, n. 2, p. 125-153.

BRESSAN, Silvio. (2002). "Reforma Administrativa”. In: LAMOUNIER, Bolívar \& FIGUEIREDO, Rubens. (orgs.). FHC: a era FHC, um balanço. São Paulo: Cultura Editores Associados.

CÂMARA DOS DEPUTADOS. [on line]. (2004). (citado 23 junho 2004) Disponível na World Wide Web:

$<$ http://www.camara.gov.br/Internet/Reformas/TramitacaoReformasCongresso.a sp> e <http://www.camara.gov.br/internet/Reformas/emendas.asp>.

CHEIBUB, José Antônio; PRZEWORSKI, Adam \& SAIEGH, Sebastian. (2002). “Governos de Coalizão nas Democracias Presidencialistas”. Dados, vol. 45, n. 2, pp. 187-218. 
CHEIBUB, Zairo B. (2000). "Reforma administrativa e relações trabalhistas no setor público: dilemas e perspectivas”. Revista Brasileira de Ciências Sociais, vol. 15, n. 43.

COSTA, Valeriano M. F. (1998). “O novo enfoque do Banco Mundial sobre o Estado”. Lua Nova, n. 44, pp. 5-26.

DIERMEIER, Daniel \& KREBHIEL, Keith. (2002). Institutionalism as a Methodology. Stanford University. mimeo.

ELSTER, Jon. (1994). Peças e Engrenagens das Ciências Sociais. Rio de Janeiro: Relume-Dumará.

ESPING-ANDERSEN, Gösta. (1991) “As três economias políticas do welfare state”. Lua Nova, n. 24, pp. 85-116. . (1995). O futuro do welfare state na nova ordem mundial. Lua Nova, n. 35, pp. 73-111.

EVANS, Peter. (1993). “O Estado como problema e solução”. Lua Nova, n. 28/29, pp. 107-157.

FIGUEIREDO, Argelina Cheibub \& LIMONGI, Fernando. (1999) Executivo e Legislativo na Nova Ordem Constitucional. Rio de Janeiro: Editora FGV.

GAETANI, Francisco. (1998). “A reforma do Estado no contexto latino-americano: comentários sobre alguns possíveis impasses e desdobramentos”. Revista do Serviço Público, ano 49, n. 2, pp. 83-102. (2000). “La intrigante reforma administrativa brasileña”. Revista Del CLAD Reforma y Democracia, n. 16, pp.1-14.

\& Heredia, Blanca. (2002). "The political economy of civil service reform in Brazil: the Cardoso Years”. Document prepared for the Red de Gestión y Transparencia del Diálogo Regional del Banco Interamericano de Desarrollo. 41p.

GRINDLE. Merilee S. (2000a) "The social agenda and the politics of reform in Latin America". In: TULCHIN, J. S. \& GARLAND, Allison M. (eds.). Social Development in Latin America. Washington: Woodrow Wilson Center. Cap. 2.

. (2000b) "Designing reforms: problems, solutions, and politics. Faculty Research Working Paper Series: John F. Kennedy School of Government, Harvard University. mimeo, pp. 1-38.

JENKINS, Kate. (2003). “A reforma do serviço público no Reino Unido”. In: PEREIRA, Luiz Carlos Bresser \& SPINK, Peter (orgs.). Reforma do Estado e Administração Pública Gerencial. 5 ed.. Rio de Janeiro. Editora FGV. 
LIMA JR., Olavo B. de. (1998). “As reformas administrativas no Brasil: modelos, sucessos e fracassos”. Revista do Serviço Público, n. 2, pp. 5-32.

LIMONGI, Fernando \& FIGUEIREDO, Argelina Cheibub. "Votações nominais na Câmara dos deputados (1989-1999)”. Banco de Dados Legislativos, Cebrap.

MARCELINO, Gileno Fernandes. (1998). "Em busca da flexibilização do Estado: o desafio das reformas planejadas no Brasil”. Palestra Proferida no Seminário Internacional Reestruturação e Reforma do Estado na FEA/USP.

MARTINS, Luciano. (1995) "Reforma da administração pública e cultura política no Brasil: uma visão geral”. Cadernos ENAP, Brasília, n. 8.

MELO, Marcus André. (2002) Reformas Constitucionais no Brasil: instituições políticas e processo decisório. Rio de Janeiro: Revan; Brasília: Ministério da Cultura.

MINISTÉRIO DA ADMINISTRAÇÃO FEDERAL E DA REFORMA DO ESTADO (MARE). (1995a). A proposta de reforma administrativa. Brasília: Presidência da República, Imprensa Oficial.

Plano diretor da reforma do aparelho do Estado (PDRAE). (1995b). Brasília: Presidência da República, Imprensa Oficial.

MORA, Mônica (2002). Federalismo e dívida estadual no Brasil. Rio de Janeiro: IPEA. Texto para Discussão n. 866.

MORROW, James. Game Theory for Political Scientists. Princeton: Princeton University Press. Capítulo 5, p. 121-157.

NICOLAU, Jairo. (2000). "Disciplina partidária e base parlamentar na Câmara dos Deputados no primeiro governo Fernando Henrique Cardoso (1995-1998)”. Dados. [online]. 2000, vol. 43, no. 4 [citado 15 Agosto 2004], p.00-00. Disponível na World Wide Web: $<$ http://www.scielo.br/scielo.php?script=sci_arttext\&pid=S0011$52582000000400004 \& \operatorname{lng}=$ pt\&nrm=iso $>$. ISSN 0011-5258.

PALERMO, Vicente. (2000). “Como se governa o Brasil? O debate sobre instituições políticas e gestão de governo”. Dados. [online]. 2000, vol. 43, no. 3 [citado 16 Agosto 2004], p.521-557. Disponível na World Wide Web: $<$ http://www.scielo.br/scielo.php?script=sci_arttext\&pid=S0011$52582000000300004 \& \operatorname{lng}=$ pt\&nrm=iso $>$. ISSN 0011-5258.

PEREIRA, Carlos e MUELLER, Bernardo. (2002). “Comportamento estratégico em presidencialismo de coalizão: as relações entre executivo e legislativo na elaboração do orçamento brasileiro”. Dados - Revista de Ciências Sociais, Rio de Janeiro, vol. 45, n. 2, pp. 265-301.

PEREIRA, Luiz Carlos Bresser. (1997). “A reforma do Estado dos anos 90: lógica e mecanismo de controle”. Lua Nova, n. 45, pp. 49-96. 
(1998). Reforma do Estado para a Cidadania: a reforma gerencial brasileira na perspectiva internacional. São Paulo: Ed. 34; Brasília: ENAP.

. (2002). "Reforma da nova gestão pública: agora na agenda da América Latina, no entanto...”. Revista do Serviço Público, ano 53, n. 1, pp. 5-27.

. (s/d). “O neoliberal disfarçado ou os percalços de uma certa lógica”. BresserPereira's Website. [citado 23 setembro 2005]. Disponível na World Wide Web: $<$ http://www.bresserpereira.org.br/PRINT.ASP?id=636>.

\& SPINK, Peter (orgs.). (2003). Reforma do Estado e Administração Pública Gerencial. 5 ed.. Rio de Janeiro. Editora FGV.

PIERSON, Paul. (1996). “The New Politics of the Welfare State”. World Politics 48.2, pp.143-179.

(2001). "Coping with permanent austerity: welfare state restructuring in affluent democracies".

Oxford: Oxford University Press.

REZENDE, Flávio da Cunha. (1998). “Clinton e a reinvenção do governo federal: o National Performance Review”. Revista do Serviço Público, ano 49, n. 1, pp. 350.

. (2000). Organizações e respostas institucionais a políticas de reformas do Estado: um estudo de caso na administração direta do executivo federal brasileiro. Revista de Sociologia Política, Curitiba, n. 14, p. 119-138.

(2002a) Por quê reformas administrativas falham? Revista Brasileira de Ciências Sociais, v. 17, n. 50, p. 123-184.

(2002b). "Razões da crise de implementação do Estado Gerencial: desempenho versus ajuste fiscal”. Revista de Sociologia Política, Curitiba, n. 19, pp. 111121.

. (2004). Por que Falham as Reformas Administrativas? Rio de Janeiro: Editora FGV.

RICHARDSON, Ruth. (2003). “As reformas no setor público da Nova Zelândia”. In: PEREIRA, Luiz Carlos Bresser \& SPINK, Peter (orgs.). Reforma do Estado e Administração Pública Gerencial. 5 ed.. Rio de Janeiro. Editora FGV.

ROCHA, Fabiana e GIUBERTI, Ana Carolina. (2004). Consenso Político com Relação à Necessidade de Disciplina: um estudo da lei de responsabilidade fiscal. Brasília: ESAF, 42 p. Monografia premiada em $2^{\circ}$ lugar no IX Prêmio Tesouro Nacional - 2004, Lei de Responsabilidade Fiscal - Tema Especial

RODRIGUES, Leôncio Martins. (2002). "Partidos, ideologia e composição social”. Revista Brasileira de Ciências Sociais, vol. 17, n. 48, pp. 31-47. 
ROMA, Celso. (2002). “A institucionalização do PSDB entre 1988 e 1999”. Revista Brasileira de Ciências Sociais, vol. 17, n. 49, pp. 71-92.

SANTOS, Fabiano. (1997). "Patronagem e Poder de Agenda na Política Brasileira”. Dados. [online]. 1997, vol. 40, no. 3 [citado 16 Agosto 2004] Disponível na World Wide Web:

$<$ http://www.scielo.br/scielo.php?script=sci_arttext\&pid=S0011$52581997000300007 \& \operatorname{lng}=$ pt\&nrm=iso $>$. ISSN 0011-5258.

(2002). "Partidos e comissões no presidencialismo de coalizão”. Dados Revista de Ciências Sociais, Rio de Janeiro, vol. 45, n. 2, pp. 237-264.

SCHNEIDER, Ben Ross. (2001). "La política de la reforma administrativa: dilemas insolubles y soluciones improbables”. Revista del CLAD Reforma y Democracia, n. 20, pp. 1-15.

SHEPHERD, G. \& VALENCIA, S. (1996). Modernizando a administração pública na América Latina: problemas comuns sem soluções fáceis. Revista do Serviço Público, vol. 120, n. 3, ano 47, p. 103-128.

SILVA, Sidney Jard da Silva. (2001). "Companheiros servidores: o avanço do sindicalismo do setor público na CUT”. Revista Brasileira de Ciências Sociais, vol. 16, n. 46, pp. 130-146. 